\title{
Gadolinium as an Emerging Microcontaminant in Water Resources: Threats and Opportunities
}

\author{
Pooria Ebrahimi ${ }^{1,2}$ and Maurizio Barbieri ${ }^{3, *(1)}$ \\ 1 Department of Earth Sciences, College of Sciences, Shiraz University, Shiraz 71454, Iran; \\ pooria.ebrahimi@gmail.com \\ 2 Department of Earth, Environment and Resources Sciences, University of Naples Federico II 80126, \\ Naples, Italy \\ 3 Department of Earth Sciences, Sapienza University of Rome, 00185 Rome, Italy \\ * Correspondence: maurizio.barbieri@uniroma1.it; Tel.: +39-06-4991-4593
}

Received: 4 January 2019; Accepted: 11 February 2019; Published: 17 February 2019

\begin{abstract}
As a result of high doses of paramagnetic gadolinium (Gd) chelates administered in magnetic resonance imaging (MRI) exams, their unmetabolized excretion, and insufficient removal in wastewater treatment plants (WWTPs), large amounts of anthropogenic $\mathrm{Gd}\left(\mathrm{Gd}_{\mathrm{anth}}\right)$ are released into surface water. The upward trend of gadolinium-based contrast agent (Gd-CA) administrations is expected to continue growing and consequently higher and higher anthropogenic $\mathrm{Gd}$ concentrations are annually recorded in water resources, which can pose a great threat to aquatic organisms and human beings. In addition, the feasibility of Gd retention in patients administered with Gd-CAs repeatedly, and even potentially fatal diseases, including nephrogenic systemic fibrosis (NSF), due to trace amounts of $\mathrm{Gd}$ have recently arisen severe health concerns. Thus, there is a need to investigate probable adverse health effects of currently marketed Gd-CAs meticulously and to modify the actual approach in using $\mathrm{Gd}$ contrast media in daily practice in order to minimize unknown possible health risks. Furthermore, the employment of enhanced wastewater treatment processes that are capable of removing the stable contrast agents, and the evaluation of the ecotoxicity of Gd chelates and human exposure to these emerging contaminants through dermal and ingestion pathways deserve more attention. On the other hand, point source releases of anthropogenic $\mathrm{Gd}$ into the aquatic environment presents the opportunity to assess surface water-groundwater interactions and trace the fate of wastewater plume as a proxy for the potential presence of other microcontaminants associated with treated wastewater in freshwater and marine systems.
\end{abstract}

Keywords: water contamination; adverse health effects; ecotoxicity; surface water-groundwater interaction; wastewater treatment; magnetic resonance imaging (MRI); gadolinium-based contrast agents (Gd-CAs)

\section{Introduction}

The upward trend of mining and using lanthanides (LAs: La to $\mathrm{Lu}$ ) in the modern world has been accompanied by the release of similarly increasing amounts of those chemicals in the environment, where their concentrations can exceed their natural values in orders of magnitude [1]. According to articles published over the last three decades, amongst LAs, anthropogenic Gd (the highly stable MRI Gd compounds that have not been fully removed in WWTPs and have been transferred to surface water) seems to be the most ubiquitous water contaminant in many countries, including Australia [2], the Czech Republic [3], Italy [4,5], France [6], the USA [7], Germany [7-9], England [10], Japan [11,12], and South Korea [13]. However, no anomalous Gd concentrations in some urban rivers, such as the Chao Phraya that runs through a densely populated area in Thailand [14], implies that 
$\mathrm{Gd}_{\text {anth }}$ inputs are mainly restricted to regions with a highly developed healthcare system and mass application of MRI tests. Positive Gd anomalies of variable size have been observed in the influent and effluent of WWTPs [13,15-17], rivers [2,7,9-12,18,19], seawaters [1,12,15,20], groundwaters [21], and tap waters $[7,10]$ due to anthropogenic Gd input.

The discharge of treated wastewater containing $\mathrm{Gd}_{\text {anth }}$ into nearby surface water bodies has provided some opportunities for hydrological studies and tracing of different microcontaminants in the treated wastewater plume [2,3]. On the other hand, it has been accompanied with some community concern, which is not irrelevant to the increasing prevalence of published scientific articles reporting the occurrence of micropollutants originating from WWTP effluents in the environment [22,23]. Microcontaminants of emerging concern (MECs), which include $\mathrm{Gd}_{\mathrm{anth}}$, are pollutants that can be detected using analytical equipment with quite low detection limits. The mechanisms of diffusion-driven transport/uptake and active transport/bioaccumulation of the Gd chelates by living organisms are of great importance, particularly when investigating feasible adverse consequences for human health if these compounds reach the human food chain. However, due to a lack of regular monitoring schemes for MECs, their toxicity is poorly understood and they are not currently regulated in the human body and the natural environment $[24,25]$.

The terms of rare elements (REs) or rare earth elements (REEs) regularly used in the literature have been confusing since they refer to different chemical elements depending on the author. REEs are commonly related to the lanthanides comprising of 15 elements, including lanthanum (La), cerium (Ce), praseodymium $(\mathrm{Pr})$, neodymium $(\mathrm{Nd})$, promethium $(\mathrm{Pm})$, samarium $(\mathrm{Sm})$, europium $(\mathrm{Eu})$, gadolinium $(\mathrm{Gd})$, terbium $(\mathrm{Tb})$, dysprosium (Dy), holmium (Ho), erbium (Er), thulium (Tm), ytterbium $(\mathrm{Yb})$, and lutetium $(\mathrm{Lu})$, in the periodic table of elements [26,27]. Amongst the lanthanides, only promethium $(\mathrm{Pm})$, a man-made radioactive element, has not yet been found in the natural environment; however, the other 14 elements are relatively abundant in geological formations and soils in a variety of chemical forms [28]. In another classification, the term, REEs, refers to the lanthanides, yttrium (Y), and scandium (Sc), which are regularly found in the same mineral assemblages due to their almost identical physicochemical characteristics [26,29]. In this review, as recommended by Kabata-Pendias [27], the term, lanthanides (LAs), will be used for the elements from La to Lu in order to avoid any confusion.

Although there is a decreasing trend in the abundance of LAs across the lanthanide series, a greater abundance of elements with an even atomic number described by the Oddo-Harkins rule leads to a zigzag pattern in the LA plots [30,31]. The elements have been categorized into different subgroups by different researchers and it continues to develop on the basis of recent scientific breakthroughs and specific aims [29]. Considering articles relating to water resources, LAs are either grouped into three classes, namely light LAs (LLAs), medium LAs (MLAs), and heavy LAs (HLAs) [32,33], or only two subgroups, including LLAs and HLAs $[13,34,35]$. Across the lanthanides, there is a difference between the organic complexation behavior of LLAs ( $\mathrm{La}$ to $\mathrm{Eu}$ ) and HLAs ( $\mathrm{Tb}$ to $\mathrm{Lu}$ ). At the junction of the two series of elements, Gd behaves as an HLA for the outer sphere (weak) complexation and as an LLA for the inner sphere (strong) complexation [36]. Although the majority of the LAs mainly exist in the 3+ state, $\mathrm{Nd}(2+, 3+$, and $5+)$ together with $\mathrm{Dy}(2+, 3+$, and $4+)$ exhibit variable valences [28].

To date, no organized monitoring schedule for Gd complexes has resulted in a comprehensive understanding of their toxicity and regulation in the body and the environment. Hence, this review introduces anthropogenic $\mathrm{Gd}$ as an overlooked emerging microcontaminant that poses a threat to human and ecological health. The main objectives of the current article review are to understand: (1) sources and fate of $\mathrm{Gd}_{\mathrm{anth}}$ in the environment; (2) challenges versus opportunities considering $\mathrm{Gd}_{\text {anth }}$ content in water resources; and (3) future research directions to fill the gaps in our understanding.

\section{Gd Discovery, Its Properties, Global Production, and Use}

Jean-Charles Gallisard de Marignac investigated the mineral, samarskite, in 1880 and found a new element, which was later named gadolinium to emphasize the great importance of the original 
REE mineral, gadolinite. Natural Gd is a mixture of six stable isotopes, which can be arranged in the abundance order of ${ }^{158} \mathrm{Gd}(24.84 \%)>{ }^{160} \mathrm{Gd}(21.86 \%)>{ }^{156} \mathrm{Gd}(20.47 \%)>{ }^{157} \mathrm{Gd}(15.65 \%)>{ }^{155} \mathrm{Gd}$ $(14.80 \%)>{ }^{154} \mathrm{Gd}(2.18 \%)$, and a radioisotope, ${ }^{152} \mathrm{Gd}(0.20 \%)$. This metal is a silvery-white, ductile and malleable LA, with a white oxide and colorless salts. Whilst it tarnishes in moist air and reacts slowly with water, it is relatively stable in dry air [37].

Over the last half-century, there was an exponential growth in the world production of rare-earth oxides (lanthanides, Sc, and Y) and the figure reached about 130,000 metric tons by 2015 because of the intense technological breakthroughs (Figure 1). Pure LAs were first prepared in 1931, but the use of individual LAs was negligible until the improvement of separation and metallurgical technologies in the 1950s [38]. Approximately four decades later, Bau and Dulski [7] published the first scientific article about the anthropogenic anomaly of $\mathrm{Gd}$ in the environment (river water) corresponding to the increasing use of Gd-CAs in MRI tests (considering Figure 1 and Figure 4, from the 1990s onward, the global rare-earth oxide production has been comparable to the number of MRI exams per 1000 inhabitants). Global reserves of rare-earth oxides (REOs) were estimated to be 100 million tonnes in 2000, with China possessing the largest proportion (43\%) of those reserves [39]. In terms of REE global production, China outnumbered other countries and supplied $98 \%$ of the REE demand [40]. Regarding their unique properties and unparalleled performance, they are critical resource materials for high technology industries and cannot currently be replaced by alternative materials $[41,42]$.

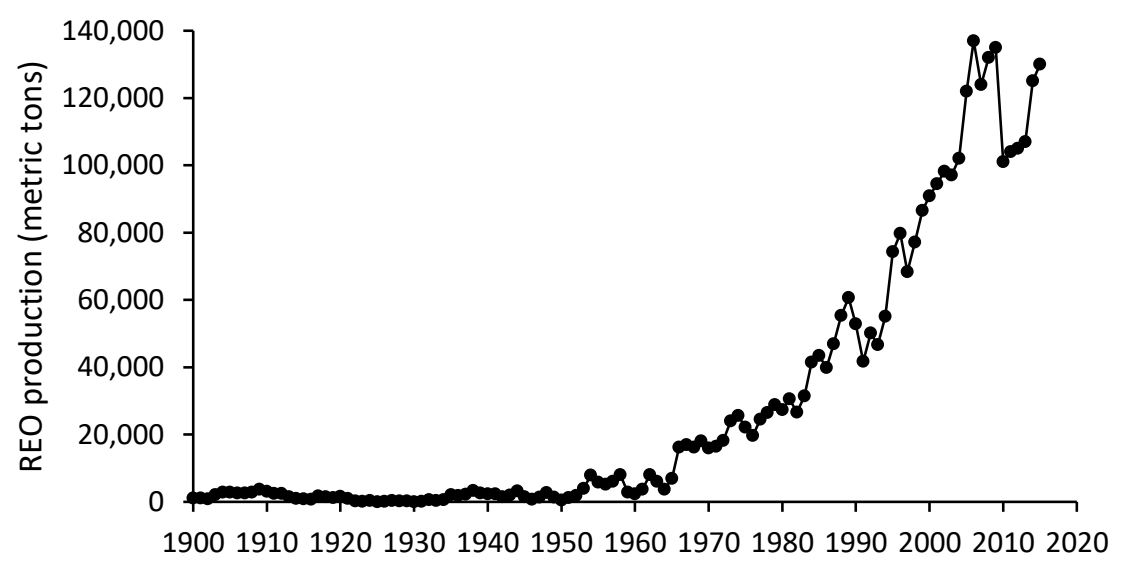

Figure 1. Global rare-earth oxide (REO) production [43].

The end uses of LAs can be divided into two broad categories, namely 'process enablers' and 'product enablers'. In the former, LAs are used in the process of production and not in the end product. In the latter, they give unique characteristics to advanced materials and play a crucial role in the performance of high-technology products [44]. The main applications of Gd in high-tech industries are listed in Table 1. 
Table 1. Different high-technology applications of Gd.

\begin{tabular}{|c|c|c|}
\hline Application Area & Description & Reference \\
\hline Glass industry & $\begin{array}{l}\mathrm{Gd}, \mathrm{Ce}, \mathrm{Pr}, \mathrm{Nd} \text {, and Er are utilized in the manufacture and polishing of glass products, } \\
\text { including lenses. }\end{array}$ & [26] \\
\hline Electronics & $\begin{array}{l}\text { (1) Gd and Eu have been used for various phosphors in computer monitors and color } \\
\text { television tubes; (2) regarding the unique magnetic characteristics of Gd, the element is used in } \\
\text { magneto-optic recording technology to handle computer data; (3) gadolinium yttrium garnets } \\
\text { are used in microwave ovens to produce the microwaves; (4) at room temperature, Gd displays } \\
\text { a strong magnetocaloric effect and can be efficiently used for either magnetic refrigeration or } \\
\text { testing other magnetic refrigeration devices; (5) permanent magnets containing Gd, Nd, Dy, } \\
\text { and Tb are used in numerous electrical and electronic components, and generators for wind } \\
\text { turbines; (6) Gd-containing crystals are used in high-power pulsed lasers; and (7) Gd oxide has } \\
\text { been used in the production of optical fibers. }\end{array}$ & {$[26,45-48]$} \\
\hline Medicine & $\begin{array}{l}\text { Gd-CAs are used as paramagnetic markers and contrast agents in MRI for medical diagnoses, } \\
\text { including vascular, myocardial, orthopedic, oncologic, inflammatory, and } \\
\text { neurological diseases. }\end{array}$ & [49-55] \\
\hline The airline and shipbuilding industries & $\begin{array}{l}\text { In the airline and shipbuilding industries, neutron radiography is used to search for hidden } \\
\text { flaws and structural weakness in hulls and fuselages. In addition to the usual film required for } \\
X \text { rays, an additional screen (a conversion screen), which is mostly made of Gd, is placed in } \\
\text { close contact with the film. }\end{array}$ & [56] \\
\hline Car industry & $\begin{array}{l}\text { Ceriumoxide and a minor fraction of Gd are generally added to three-way catalysts to promote } \\
\text { the watergas shift reaction. }\end{array}$ & [57] \\
\hline Metallurgy & $\begin{array}{l}\text { The addition of } \mathrm{Gd} \text { to } \mathrm{Fe} \text { and } \mathrm{Cr} \text { alloys improves their workability and resistance to oxidation } \\
\text { and high temperatures. }\end{array}$ & [58] \\
\hline Energy & $\begin{array}{l}\text { The high melting points and high thermal neutron absorption cross-sections of Gd, Sm, Eu, } \\
\text { and Dy are two properties that make them ideal for uses in nuclear reactor control rod } \\
\text { applications. The rods are raised out of or lowered into the reactor, allowing for more or fewer } \\
\text { neutrons to remain in the nuclear fission reaction. Power plant radiation leaks can also be } \\
\text { detected by Gd, being the most efficient detector. }\end{array}$ & {$[26,45,58]$} \\
\hline
\end{tabular}




\section{Natural Gd}

Monazite, bastnaesite, and gadolinite account for Gd typical minerals, and feldspars, apatite, allanite, sphene, fluorite, and zircon are the possible host minerals [59]. Whilst the data on individual LAs in soil are scanty, the geological origin of parent rocks and their mineral composition evidently determine the trend of LA distribution in various soils [28]. According to Korzh [60], the rate of Gd deposition from oceans via the atmosphere onto soils is low, being 1 to $10 \mathrm{t} / \mathrm{yr}$. On average, cabbages from the background area of Denmark contain Gd within the range of $0.15-2.60 \mu \mathrm{g} / \mathrm{kg}$ wet weight [61]. Eriksson [62] reported 0.001 to $0.01 \mu \mathrm{g} / \mathrm{L} \mathrm{Gd}$ in rainwaters collected in Sweden during 1999.

Data for the LAs are among the most widely used geochemical tools in the earth and environmental sciences $[13,19,33,63,64]$. In unpolluted natural fresh waters, LA concentrations commonly range between $\mathrm{ng} / \mathrm{g}$ and low-pg/g (ppb and ppt), and saline waters are typically in the $\mathrm{fg} / \mathrm{g}$ (ppq) range [65]. Total Gd concentrations and Gd anomalies found in uncontaminated aqueous samples are provided in Table 2. Chemical weathering is a prominent process that partially mobilizes lanthanides as dissolved loads in surface water, during which physicochemical characteristics, such as $\mathrm{pH}$, salinity, flow conditions [66-69], and bedrock lithology, regulate the dissolved LA content [69-71]. LA patterns are thought to be great indicators of overall river basin processes (e.g., chemical weathering and transportation processes) due to the relative consistency of physicochemical properties and bedrock types within a river; except in cases where either atmospheric wet and dry deposition or anthropogenic lanthanides significantly alters the dissolved LA load by orders of magnitude [19,72-74]. Due to this invariable coherent behavior in biogeochemical processes, LA patterns are a prevalent geochemical tool for the interpretation of the dissolved load content of natural waters [24,75-77]. 
Table 2. Total Gd concentrations and Gd anomalies reported in uncontaminated aqueous samples. The subscript, SN, denotes the normalization to the Gd content in the continental crust (regularly PAAS was used) and the superscript * denotes the natural background value.

\begin{tabular}{|c|c|c|c|c|c|c|c|c|}
\hline Sample & Study Area & Filtration & Acidification & Instrument & Detection Limit & Gd & $\mathrm{Gd}_{\mathrm{SN}} / \mathrm{Gd}^{*}{ }_{\mathrm{SN}}$ & Reference \\
\hline \multirow{8}{*}{ Tapwater } & Eastern Berlin, Germany & $0.2 \mu \mathrm{m}$ & $\mathrm{pH}=1.8-2.0$ & ICP-MS & 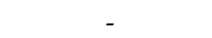 & $2.3-4.2 \mathrm{pmol} / \mathrm{L}$ & $0.95-1.70^{1}$ & [10] \\
\hline & Wivenhoe Dam, Australia & $0.22 \mu \mathrm{m}$ & $\mathrm{pH}=1.5$ & ICP-MS & $480 \mathrm{fmol} / \mathrm{L}$ & $16.0 \mathrm{pmol} / \mathrm{kg}$ & $1.07^{2}$ & [16] \\
\hline & Somerset Dam, Australia & $0.22 \mu \mathrm{m}$ & $\mathrm{pH}=1.5$ & ICP-MS & $480 \mathrm{fmol} / \mathrm{L}$ & $64.3 \mathrm{pmol} / \mathrm{kg}$ & $1.09^{2}$ & [16] \\
\hline & Hinze Dam, Australia & $0.22 \mu \mathrm{m}$ & $\mathrm{pH}=1.5$ & ICP-MS & $480 \mathrm{fmol} / \mathrm{L}$ & $233.1 \mathrm{pmol} / \mathrm{kg}$ & $1.08^{2}$ & [16] \\
\hline & North Pine Dam, Australia & $0.22 \mu \mathrm{m}$ & $\mathrm{pH}=1.5$ & ICP-MS & $480 \mathrm{fmol} / \mathrm{L}$ & $11.1 \mathrm{pmol} / \mathrm{kg}$ & $1.07^{2}$ & [16] \\
\hline & Mt Crosby Weir, Australia & $0.22 \mu \mathrm{m}$ & $\mathrm{pH}=1.5$ & ICP-MS & $480 \mathrm{fmol} / \mathrm{L}$ & $21.9 \mathrm{pmol} / \mathrm{kg}$ & $1.05^{2}$ & [16] \\
\hline & Brisbane, Australia & $0.22 \mu \mathrm{m}$ & $\mathrm{pH}=1.5$ & ICP-MS & $480 \mathrm{fmol} / \mathrm{L}$ & $15.5 \mathrm{pmol} / \mathrm{kg}$ & $1.04^{2}$ & [16] \\
\hline & Prague, Czech Republic & $0.2 \mathrm{~mm}$ & $\mathrm{pH}=2.0$ & ICP-MS & - & $2.1 \mathrm{nmol} / \mathrm{m}^{3}$ & $1.20^{2}$ & [3] \\
\hline \multirow[t]{13}{*}{ River water } & Wangsuk stream, South Korea & $0.2 \mu \mathrm{m}$ & $\mathrm{pH}=2.0$ & Q-ICP-MS & - & $26.0 \mathrm{pmol} / \mathrm{L}$ & $1.34^{3}$ & [13] \\
\hline & Anyang stream, South Korea & $0.2 \mu \mathrm{m}$ & $\mathrm{pH}=2.0$ & Q-ICP-MS & - & $26.0 \mathrm{pmol} / \mathrm{L}$ & $1.21^{3}$ & [13] \\
\hline & Changneung stream, South Korea & $0.2 \mu \mathrm{m}$ & $\mathrm{pH}=2.0$ & Q-ICP-MS & - & $35.6 \mathrm{pmol} / \mathrm{L}$ & $1.39^{3}$ & [13] \\
\hline & Wiembach Creek, Germany & $0.2 \mu \mathrm{m}$ & $\mathrm{pH}=1.8-2.0$ & ICP-MS & - & $1.5 \mathrm{ng} / \mathrm{kg}$ & $0.98^{1}$ & [9] \\
\hline & Spring Creek, USA & $0.2 \mu \mathrm{m}$ & $\mathrm{pH}=2.0$ & ICP-MS & $0.01-0.1 \mathrm{pg} / \mathrm{mL}$ & $26.3 \mathrm{pmol} / \mathrm{L}$ & $1.15^{3}$ & [18] \\
\hline & Delaware River, USA & $0.2 \mu \mathrm{m}$ & $\mathrm{pH}=2.1$ & ICP-MS & $0.01-0.1 \mathrm{pg} / \mathrm{mL}$ & $23.9 \mathrm{pmol} / \mathrm{L}$ & $1.47^{3}$ & [18] \\
\hline & Ibi River, Japan & $0.45 \mu \mathrm{m}$ & $\mathrm{pH}=1$ & ICP-MS & $0.027 \mathrm{ng} / \mathrm{L}$ & $3.5 \mathrm{ng} / \mathrm{L}$ & $1.36^{3}$ & [12] \\
\hline & Nagara River, Japan & $0.45 \mu \mathrm{m}$ & $\mathrm{pH}=1$ & ICP-MS & $0.027 \mathrm{ng} / \mathrm{L}$ & $3.9 \mathrm{ng} / \mathrm{L}$ & $1.41^{3}$ & [12] \\
\hline & Kiso River, Japan & $0.45 \mu \mathrm{m}$ & $\mathrm{pH}=1$ & ICP-MS & $0.027 \mathrm{ng} / \mathrm{L}$ & $5.3 \mathrm{ng} / \mathrm{L}$ & $1.31^{3}$ & [12] \\
\hline & Amazon River, South America & $0.2 \mu \mathrm{m}$ & - & ICP-MS & - & $0.0123 \mu \mathrm{g} / \mathrm{L}$ & $1.20^{1}$ & [78] \\
\hline & Toshibetsu River, Japan & $0.2 \mu \mathrm{m}$ & $\mathrm{pH}=1.9-2.1$ & ICP-MS & - & $77.4 \mathrm{pmol} / \mathrm{kg}$ & $1.20^{3}$ & [7] \\
\hline & Västerdalälven River, Sweden & $0.2 \mu \mathrm{m}$ & $\mathrm{pH}=1.9-2.1$ & ICP-MS & - & $265.0 \mathrm{pmol} / \mathrm{kg}$ & $1.20^{3}$ & [7] \\
\hline & Dhünn River, Germany & $0.2 \mu \mathrm{m}$ & $\mathrm{pH}=1.9-2.1$ & ICP-MS & - & $8.9 \mathrm{pmol} / \mathrm{kg}$ & $1.60^{3}$ & [7] \\
\hline \multirow{3}{*}{ Groundwater } & Hind Well, Hawaii & $0.45 \mu \mathrm{m}$ & $\mathrm{pH}<2$ & HR-ICP-MS & $0.5-6.0 \mathrm{pmol} / \mathrm{kg}$ & $41.2 \mathrm{pmol} / \mathrm{kg}$ & $1.08^{3}$ & [21] \\
\hline & Berlin, Germany & $0.2 \mu \mathrm{m}$ & $\mathrm{pH}=1.8-2.0$ & ICP-MS & - & $8.4 \mathrm{pmol} / \mathrm{L}$ & $1.12^{1}$ & [10] \\
\hline & Vlastejovice spring, Czech Republic & $0.2 \mathrm{~mm}$ & $\mathrm{pH}=2.0$ & ICP-MS & - & $19.4 \mathrm{nmol} / \mathrm{m}^{3}$ & $1.00^{2}$ & [3] \\
\hline Lake water & Lake Värmeln, Sweden & $0.2 \mu \mathrm{m}$ & $\mathrm{pH}=1.9-2.1$ & ICP-MS & - & $232.0 \mathrm{pmol} / \mathrm{kg}$ & $1.20^{3}$ & [7] \\
\hline \multirow[t]{3}{*}{ Seawater } & North Atlantic seawater & $0.45 \mu \mathrm{m}$ & $\mathrm{pH}=1.8-2.0$ & ICP-MS & - & $5.4 \mathrm{pmol} / \mathrm{L}$ & $1.60^{4}$ & [15] \\
\hline & Japan Sea (Nie coast) & $0.45 \mu \mathrm{m}$ & $\mathrm{pH}=1$ & ICP-MS & $0.027 \mathrm{ng} / \mathrm{L}$ & $1.9 \mathrm{ng} / \mathrm{L}$ & $0.96^{3}$ & [12] \\
\hline & Western North Pacific, Japan & $0.04 \mu \mathrm{m}$ & $\mathrm{pH}<1.5$ & ICP-MS & - & $2.1 \mathrm{pmol} / \mathrm{kg}$ & $1.05^{3}$ & [79] \\
\hline
\end{tabular}

ICP-MS = Inductively coupled plasma-mass spectrometry; Q-ICP-MS = Quadrupole-inductively coupled plasma-mass spectrometry; HR-ICP-MS = High-resolution-inductively coupled

plasma-mass spectrometry. ${ }^{1}$ 
After excluding the likely anomalous LAs ( $\mathrm{La}, \mathrm{Ce}, \mathrm{Eu}, \mathrm{Gd}$, and $\mathrm{Lu}$ ), various methods can be used to calculate natural background Gd [3,15,16,80], including (i) linear (or geometric) extrapolation from either the HLAs or the LLAs, (ii) linear (or geometric) interpolation between a HLA and a LLA, or (iii) the third order polynomial fit, which models the shape of the normalized LA pattern. When employing LA values to calculate $\mathrm{Gd}$ anomalies (for example, $\mathrm{Gd}_{\mathrm{SN}} / \mathrm{Gd}_{\mathrm{SN}}{ }_{\mathrm{SN}}=\mathrm{Gd}_{\mathrm{SN}} /\left(0.33 \mathrm{Sm}_{\mathrm{SN}}+0.67 \mathrm{~Tb}_{\mathrm{SN}}\right)$ ), the use of arithmetic means is not correct because the logarithmic scale of LA plots leads to serious errors (particularly for steep normalized LA patterns) [81]. Amongst the abovementioned approaches, the last one is the only method that makes no implicit assumption whether Gd behaves as an LLA or an HLA. The application of this method is consequently more compelling as it can be employed for the whole range of waters, from wastewater to freshwater and seawater. Further, with regards to the results obtained by this approach, comparing results between different studies and geographical areas can be facilitated [20].

To detect LA anomalies in the sample of interest and improve their comparison with data from elsewhere, the naturally occurring Oddo-Harkins effect (the saw-tooth effect) in the lanthanide sequence needs to be smoothed out by dividing each measured LA value by the concentration of the same element in the continental crust. To date, LA contents of the Post-Archean Australian Shale (PAAS; [81]), the North American Shale Composite (NASC; [82]), the upper continental crust (UCC; [83]), and the Average Shale data [84] have been used to normalize LA concentrations in water $[13,64,85,86]$. PAAS, the most widely used composite as it represents the best average of the earth's crust [3], has been evaluated for abundances of the monoisotopic LAs and no accuracy was found in terms of Pr and Tm [87]. Thus, Lawrence et al. [88] used the Mud of Queensland (MUQ; [87], a local composite sediment average, for the normalization and calculation of Gd anomalies. Figure 2 represents MUQ-normalized LA patterns of river waters with and without anthropogenic Gd and wastewater samples with a remarkable positive Gd anomaly. In the typical LA patterns for natural water, the relative concentrations of HLAs are higher than those of LLAs [12]. Moreover, there is a continuous trend from $\mathrm{La}$ to $\mathrm{Gd}$ prior to a decline to a lower level and another trend from $\mathrm{Tb}$ to $\mathrm{Lu}$ in the LA plot of pristine rivers, such as Västerdaläven and Toshibetsu and Dhünn [7] (Figure 2a). The larger slopes from LLAs to HLAs might be due to the higher complexing abilities of HLAs with dissolved organic substances and the preferential incorporation of LLAs in the formation of secondary minerals $[12,24,89]$. However, in waters with less organic substances, submicron particles or colloids containing LLAs more than HLAs pass through the membrane filters with a pore size of $0.45 \mu \mathrm{m}$ and lead to a flat LA distribution pattern $[89,90]$. 

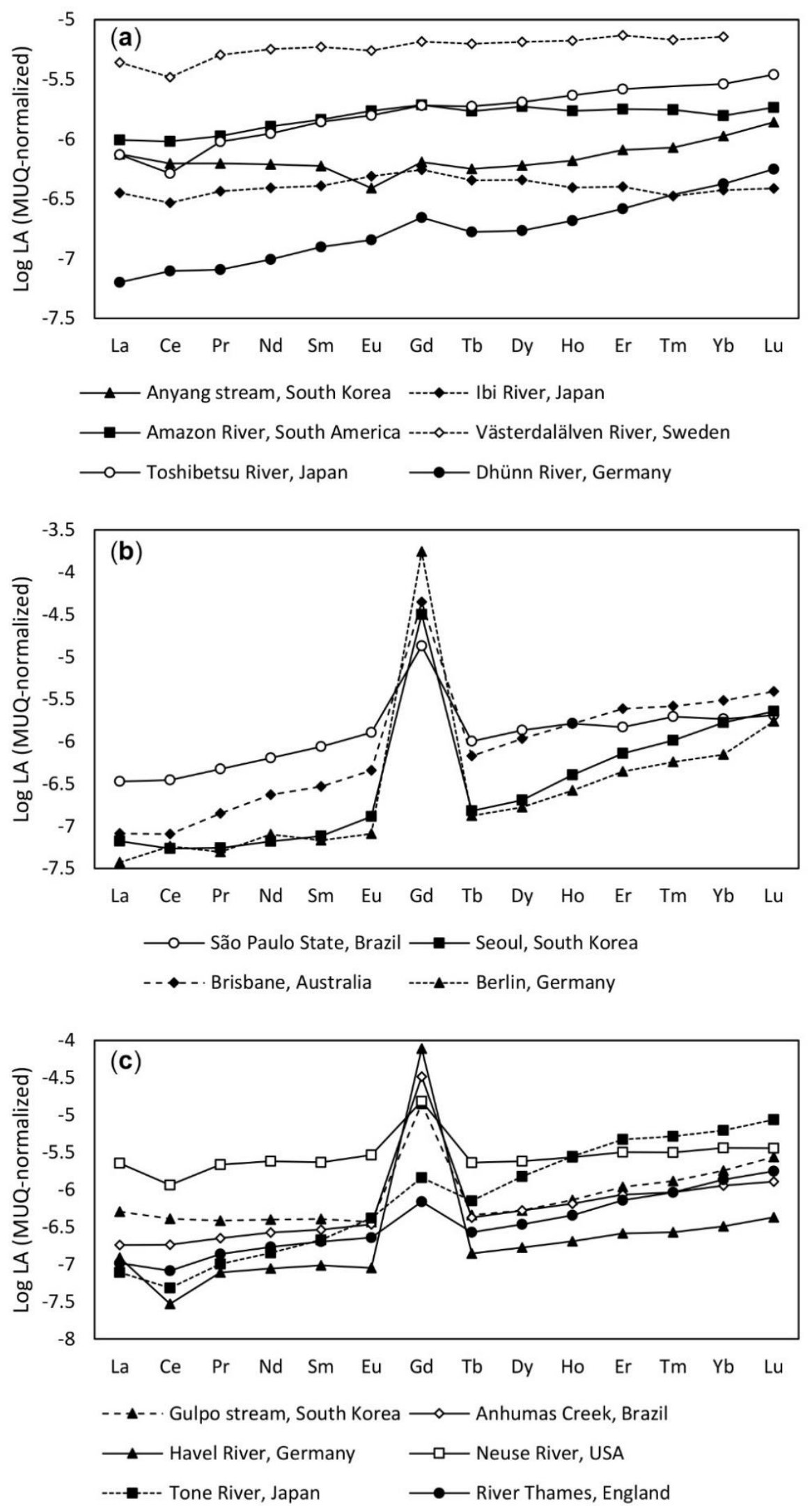

Figure 2. MUQ-normalized LA patterns of: (a) River waters without $\mathrm{Gd}_{\mathrm{anth}}$; (b) WWTP effluents with

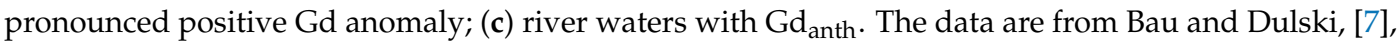
Nozaki et al. [11], Gaillardet et al. [78], Zhu et al. [12], Lawrence et al. [16], Kulaksiz and Bau [10], de Campos and Enzweiler [17], Song et al. [13], and Smith and Liu [19]. 
The calculation of Gd anomaly using a formula is based on the assumption that normalized values of LAs vary smoothly with an increasing atomic number. Although no positive Gd anomaly is expected in pristine river waters, Bau and Dulski [7] reported $\mathrm{Gd}_{\mathrm{SN}} / \mathrm{Gd}^{*} \mathrm{SN}$ ratios of 1.2 for the Västerdaläven and Toshibetsu rivers and 1.9 for the Dhünn river. Since there was a smooth trend from Pr to $\mathrm{Gd}$, and another smooth trend from $\mathrm{Tb}$ to $\mathrm{Lu}$ in normalized LA patterns of the collected river water samples (Figure 2a), Bau and Dulski [7] concluded that $\mathrm{Gd}_{\mathrm{SN}} / \mathrm{Gd}^{*}{ }_{\mathrm{SN}}$ ratios above the unity do not necessarily indicate an occurrence of positive anomalous $\mathrm{Gd}$ and the complete normalized LA pattern should also be considered. Due to the unique position of Gd amongst the two groups with different complexation behavior, anomalous Gd may appear regarding the complexation behavior of its immediate neighbors as well [36].

Slight, positive $\mathrm{Gd}$ anomalies were identified as a common feature of seawater, which systematically changes with depth. The observed rapid changes in the upper several hundred meters suggest that both ocean circulation and biogeochemical cycles greatly govern seawater $\mathrm{Gd}$ distribution [79]. Irrespective of the normalization problem, natural positive Gd anomaly in seawater is also attributed to the "tetrad" effect because the considerable high Gd stability might result from the half-filled $4 \mathrm{f}$ electron shell [91]. Further, positive Gd anomaly and distinct negative $\mathrm{Tb}$ and $\mathrm{Tm}$ anomalies in shale-normalized LA patterns of seawaters were explained by the complexation behavior of LAs with carbonate ions in seawater [92].

\section{Anthropogenic $\mathrm{Gd}\left(\mathrm{Gd}_{\mathrm{anth}}\right)$}

Contrary to the highly stable Gd-CAs used in medicine, the Gd load emitted by other sources or the Gd used in other high-technology applications (Table 1) probably have different toxicities and responses to treatment processes. It seems unlikely that the Gd utilized for these purposes cannot be removed during sewage treatment and end up polluting water resources. The figures for patients who undergo MRI exams and the global administration of Gd-CAs will continue to grow because of the increasing number of available MRI scanners worldwide. Therefore, a large and continuously increasing amount of $\mathrm{Gd}$ enters the aqueous environment and enriches Gd over LAs more and more [93]. However, there is no standard for Gd-CAs that regulates their concentrations in sewage effluents or receiving water bodies, partly because of the insufficient knowledge about the ecological effects of LAs [1]. Regarding the stability of Gd-CAs and their potentially high half-lives (i.e., more than three months [94]) in the environment, it is of the utmost importance that the amount of $\mathrm{Gd}_{\text {anth }}$ in the aquatic environment and also its environmental fate are investigated in more detail. Generally, the inputs and concentrations of $\mathrm{Gd}_{\text {anth }}$ into the public sewage system and the environment vary greatly depending on the population size, level of access to health systems, and the number of hospitals and clinics performing MRI imaging [1]. In the following sections, elevated concentrations of Gd in water resources, which can be traced back to the application of Gd-CAs in MRI exams and the inefficiency of treatment mechanisms in WWTPs, are reviewed to highlight the potential impacts and benefits of mitigation measures.

\subsection{Gd-CAs in MRI}

Since the first generation of an image using nuclear magnetic resonance in 1973, non-invasive diagnostic techniques, such as MRI, have been developed as an indispensable method in modern medicine. Although contrast agents are not necessary for MRI exams, $0.1 \mathrm{mmol}$ of $\mathrm{Gd}$ per $\mathrm{kg}$ of body weight (average body weight is $70 \mathrm{~kg}$ [95]) has been applied in about $40 \%$ of MRI exams [96,97]. In comparison with other paramagnetic elements, such as manganese, dysprosium, iron, and copper, the paramagnetic characteristics of $\mathrm{Gd}^{3+}$ are unparalleled [98]. The seven unpaired electrons of $\mathrm{Gd}^{3+}$ account for its strong magnetic momentum, enabling the element to polarize ${ }^{1} \mathrm{H}$ water protons, which indicate an increased T1 relaxation rate when aligned in magnetic fields [99]. It leads to higher signal-to-noise ratios (SNRs), clarity, contrast, and detail for the differentiation of tissues in the MRI images. Since clinical approval of the first contrast agent (Magnevist ${ }^{\circledR}$ ) in 1987, the overall 
administration of various Gd chelates is estimated to have been more than 300 million [100]. Today, the paramagnetic $\mathrm{Gd}$ chelates are annually used in about 30 million MRI exams, which is approximately $50 \%$ greater than the estimated 2005 figure [100,101].

Regarding the chelate type and charge, Gd-CAs can be divided into linear/macrocyclic and ionic/non-ionic groups. A wide range of Gd-CAs are commercially available and their stability is dependent on the conditional thermodynamic stability constant $\left(\mathrm{K}_{\mathrm{cond}}\right)$, thermodynamic stability constant $\left(\mathrm{K}_{\text {therm }}\right)$, and kinetic stability (Figure 3; Table 3) [97]. Higher values of $\mathrm{K}_{\text {cond }}$ (at physiological $\mathrm{pH}$ tests) and $\mathrm{K}_{\text {therm }}$ imply a greater $\mathrm{Gd}$ affinity for ligands, higher stability of $\mathrm{Gd}$ complexes, and less free gadolinium ion [102,103]. The rate of Gd release from its ligand (half-life) is also tested at a low $\mathrm{pH}$ using kinetic stability. Greater kinetic stability denotes a longer period of time prior to dissociation (Table 3). Ionic Gd-CAs are more stable than nonionic ones and the stability of macrocyclic compounds is higher than linear compounds. Hence, ionic macrocyclic agents are the most stable $\mathrm{Gd}$ chelates. Macrocyclic molecules bind strongly to Gd in an organized rigid ring; however, linear nonionic Gd-CAs have open chains and weaker binding to $\mathrm{Gd}$. Compared to linear agents, macrocyclic agents are more stable in vivo. Low-stability Gd-CAs (linear, nonionic compounds) likely undergo transmetallation, release free Gd that deposits in tissues, attract fibrocytes, and therefore initiate the process of fibrosis $[101,104]$.

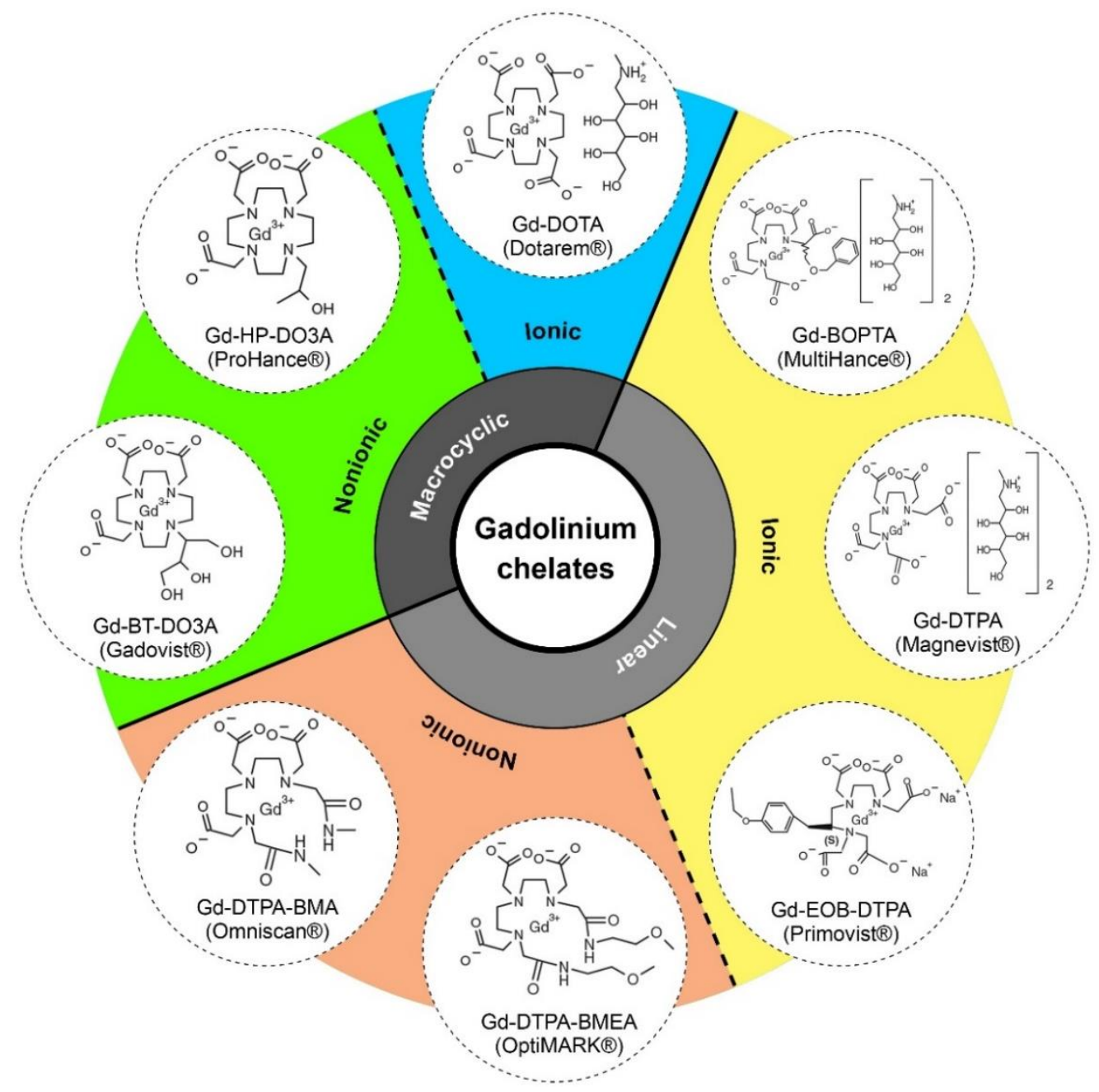

Figure 3. Structure of currently marketed Gd-CAs used for MRI [102]. 
Table 3. Characteristics of currently marketed Gd-CAs approved by the U.S. Food and Drug Administration for body magnetic resonance imaging [101,103,105-110] and the proportion of pediatric radiology departments used Gd-CAs in 2010 and 2016 [111,112]. Dosage of all Gd-CAs is $0.1 \mathrm{mmol} / \mathrm{kg}$, with the exception of gadoxetate disodium $(0.025 \mathrm{mmol} / \mathrm{kg})$.

\begin{tabular}{|c|c|c|c|c|c|c|c|c|c|c|}
\hline $\begin{array}{l}\text { Chemical } \\
\text { Structure }\end{array}$ & $\begin{array}{l}\text { Chemical Name } \\
\text { (Acronym) }\end{array}$ & Trade Name & Manufacturer & $\begin{array}{c}\text { Conditional } \\
\text { Thermodynamic } \\
\text { Stability } \\
\text { Constant (Log } \\
\mathrm{K}_{\text {cond }} \text { at pH 7.4) }\end{array}$ & $\begin{array}{c}\text { Thermodynamic } \\
\text { Stability } \\
\text { Constant (Log } \\
\left.\mathbf{K}_{\text {therm }}\right)\end{array}$ & $\begin{array}{c}\text { Kinetic } \\
\text { Stability T1/2 } \\
\text { at pH }=1.0 \\
\text { and } \mathrm{T}=25^{\circ} \mathrm{C}\end{array}$ & NFS Risk ${ }^{1}$ & $\begin{array}{c}\text { Global } \\
\text { Administration } \\
\text { in } 2010 \\
\text { (million) }\end{array}$ & $\begin{array}{l}\text { \% of Clinics } \\
\text { Used Each } \\
\text { Gd-CA } \\
\text { in } 2010\end{array}$ & $\begin{array}{l}\text { \% of Clinics } \\
\text { Used Each } \\
\text { Gd-CA } \\
\text { in } 2016\end{array}$ \\
\hline $\begin{array}{l}\text { Linear } \\
\text { nonionic }\end{array}$ & $\begin{array}{c}\text { Gadodiamide } \\
\text { (Gd-DTPA-BMA) }\end{array}$ & Omniscan $^{\circledR}$ & $\begin{array}{l}\text { GE Healthcare } \\
\text { (Little Chalfont, } \\
\text { UK) }\end{array}$ & 14.9 & 16.9 & $<5 \mathrm{~s}$ & High & 49 & 10 & 0 \\
\hline $\begin{array}{l}\text { Linear } \\
\text { nonionic }\end{array}$ & $\begin{array}{l}\text { Gadoversetamide } \\
\text { (Gd-DTPA-BMEA) }\end{array}$ & OptiMARK $^{\circledast}$ & $\begin{array}{l}\text { Guerbet } \\
\text { (Villepinte, } \\
\text { France) }\end{array}$ & 15 & 16.6 & $<5 \mathrm{~s}$ & High & 3.5 & 2 & 0 \\
\hline Linear ionic & $\begin{array}{l}\text { Gadopentetate } \\
\text { dimeglumine } \\
\text { (Gd-DTPA) }\end{array}$ & Magnevist $^{\circledR}$ & $\begin{array}{c}\text { Bayer } \\
\text { HealthCare } \\
\text { (Berlin, } \\
\text { Germany) } \\
\end{array}$ & 17.7 & 22.1 & $<5 \mathrm{~s}$ & High & 105 & 81 & 15 \\
\hline Linear ionic & $\begin{array}{l}\text { Gadobenate } \\
\text { dimeglumine } \\
\text { (Gd-BOPTA) }\end{array}$ & MultiHance ${ }^{\circledR}$ & $\begin{array}{c}\text { Bracco } \\
\text { Diagnostics } \\
\text { (Milan, Italy) }\end{array}$ & 18.4 & 22.6 & $<5 \mathrm{~s}$ & Intermediate & 7.5 & 38 & 9 \\
\hline Linear ionic & $\begin{array}{c}\text { Gadoxetate } \\
\text { disodium } \\
\text { (Gd-EOB-DTPA) }\end{array}$ & Eovist $^{\circledast} /$ Primovist $^{\circledast}$ & $\begin{array}{c}\text { Bayer } \\
\text { HealthCare } \\
\text { (Berlin, } \\
\text { Germany) }\end{array}$ & 18.7 & 23.5 & $\mathrm{~N} / \mathrm{A}^{2}$ & Intermediate & 0.4 & - & - \\
\hline $\begin{array}{c}\text { Macrocyclic } \\
\text { nonionic }\end{array}$ & $\begin{array}{c}\text { Gadoteridol } \\
\text { (Gd-HP-DO3A) }\end{array}$ & ProHance ${ }^{\circledR}$ & $\begin{array}{c}\text { Bracco } \\
\text { Diagnostics } \\
\text { (Milan, Italy) }\end{array}$ & 17.1 & 23.8 & $3.9 \mathrm{~h}$ & Low & 15 & 14 & 4 \\
\hline $\begin{array}{c}\text { Macrocyclic } \\
\text { nonionic }\end{array}$ & $\begin{array}{c}\text { Gadobutrol } \\
\text { (Gd-BT-DO3A) }\end{array}$ & Gadovist $^{\circledR}$ & $\begin{array}{c}\text { Bayer } \\
\text { HealthCare } \\
\text { (Berlin, } \\
\text { Germany) }\end{array}$ & 14.7 & 21.8 & $43 \mathrm{~h}$ & Low & 6 & 39 & 42 \\
\hline $\begin{array}{l}\text { Macrocyclic } \\
\text { ionic }\end{array}$ & $\begin{array}{l}\text { Gadoterate } \\
\text { meglumine } \\
\text { (Gd-DOTA) }\end{array}$ & Dotarem $^{\circledR}$ & $\begin{array}{l}\text { Guerbet } \\
\text { (Villepinte, } \\
\text { France) }\end{array}$ & 19.3 & 25.6 & $338 \mathrm{~h}$ & Low & 22.4 & $\mathrm{~N} / \mathrm{A}$ & 38 \\
\hline
\end{tabular}

${ }^{1}[113]^{2}$ not applicable. 
Polyaminocarboxylic acid chelating agents are mostly complexed with $\mathrm{Gd}$ to produce thermodynamically stable linear or macrocyclic complexes, guaranteeing their fast, complete, and unmetabolized urinary excretion from the human body, and avoiding the high toxicity of free $\mathrm{Gd}^{3+}[101,106,114,115]$. Hence, Gd-CAs pose a lower risk of allergies and interaction with patients than other contrasts, such as iodinated contrast [96].

\subsection{Gd Determination in the Aqueous Environment}

As indirect potable reuse of purified wastewater poses a threat to wildlife and human health, it is crucial to monitor micropollutants in the environment. However, analytical detection limits restrict our capability to quantify their presence and assess their human health consequences. Therefore, it is imperative to be equipped with some alternative strategies to overcome the challenges [16].

Analytically, the most accurate and precise techniques are isotope dilution methods requiring the equilibration of an enriched isotopic spike with the sample before analysis. For this reason, obtaining the concentration of the monoisotopic elements ( $\mathrm{Y}, \mathrm{Pr}, \mathrm{Tb}, \mathrm{Ho}$, and $\mathrm{Tm}$ ) by isotope dilution is impossible. The importance of the monoisotopic element concentrations for quantifying the behavior of the 'anomalous' elements was enlightened when more LA data for seawater and hydrogenous sediments became available [116]. Utilizing multi-element isotope dilution inductively coupled plasma-mass spectrometry (ID ICP-MS), Behrens et al. [117] reported the first application of the automated seaFAST-pico system in the offline mode for rapid and robust purification, pre-concentration, and analysis of dissolved LAs from small volumes (11 to $12 \mathrm{ml}$ ) of seawater. In extraction techniques (either solid phase extraction or liquid-liquid extraction), samples are exposed to other reagents, making it quite challenging to maintain process blanks below the levels required to quantify the LA accurately [118]. Nonetheless, using external calibration, ICP-MS methods are capable of quantifying the complete set of LAs and produce a dataset that may be used to elucidate the origin and significance of the LA pattern. When ICP-MS is used to analyze fresh and marine waters directly, sample manipulation and the corresponding risk of blank contamination are minimized, leading to even better quality data [65].

Lawrence et al. [16] demonstrated an ICP-MS technique that was capable of measuring $\mathrm{Gd}_{\text {anth }}$ in tap waters, the surface waters of water supply reservoirs, and WWTP effluents at concentrations as low as $48 \mathrm{fmol} / \mathrm{L}$ without the need for preconcentration. It was roughly six orders of magnitude lower than the detection limits for chemical methods determining representative pharmaceutical compounds in natural water resources (for instance, Diazepam in river water) where the limit of detection is $0.02 \mu \mathrm{g} / \mathrm{L}$ (70 nmol/L) after a 1000-fold preconcentration [119]. They collected filtered water samples in trace metal cleaned bottles, which were immediately acidified to $\mathrm{pH} 1.5$ prior to analysis at laboratory. While maintaining oxide production under $2 \%$ (measured by $\mathrm{CeO} / \mathrm{Ce}$ ), samples were analyzed with ICP-MS tuned for maximum sensitivity using the high performance sample introduction system, which has the best signal to noise ratio. Correction of the raw instrument data was applied for variations in the internal standard, external drift, and interfering oxides. Hotplate digests for the US Geological Survey (USGS) dolerite reference material, W-2, were then utilized to calibrate the instrument response. A similar procedure was undertaken by Lawrence et al. [118] to assess the removal of paramagnetic $\mathrm{Gd}$ chelates through advanced water treatment plants. In the samples collected from the reverse osmosis (RO) permeate with an exceptionally clean matrix relative to most other sample types, LA concentrations were under the detection limit of the method. Thus, they considered evaporation (sub-boiling) as the most appropriate preconcentration method. In another investigation, a seaFAST 2 automated sample introduction system was interfaced with Q-ICP-MS to measure LA concentrations when approximately $25 \mathrm{ml}$ of water samples was dried and the residue was treated with concentrated $\mathrm{HNO}_{3}$, dried, and subsequently dissolved in $5 \% \mathrm{HNO}_{3}$ again [13].

Nevertheless, direct LA determination in water with ICP-MS is still challenging because of low LA concentrations, the matrix effect, and potential spectral interferences (isobaric and polyatomic). High salt contents in seawater result in signal suppression, instrument sensitivity drift, and clogging 
of the sample introduction and ions extraction systems. In addition, in plenty of environmental samples, some coexisting elements, such as $\mathrm{Ba}, \mathrm{Sn}$, and $\mathrm{Sb}$, likely bring serious spectral interference (oxides ions and hydroxides) during the determination of La, Ce, and Eu by means of ICP-MS [120]. To overcome the problems and obtain more accurate and reliable analytical data through sensitive and interference-free determination, a preconcentration step regularly precedes the measurements.

Amongst various separation and preconcentration methods, approaches in which LAs are sorbed on different water-insoluble solid materials and further eluted with either acids or complexing reagents have been greatly used (Table 4). Solid phase extraction (SPE) procedures offer some important advantages in comparison with classical liquid-liquid extraction (LLE) techniques, including high enrichment factor, reduced organic solvents usage and exposure, rapid phase separation, and the feasibility of a combination with different detection techniques [121]. The other factors that make this technique very attractive for sample pretreatment are the various sorbent materials together with the broad range of chelating reagents and eluents. Furthermore, to appropriately perform sample pretreatment, they can be implemented and controlled in flow systems easily. Simple adsorption, ion-exchange, or complexation are the mechanisms of sorption, which are dependent on the nature of a given sorbent. Choosing solid material for the enrichment and removal of LAs ought to be based on the sample matrix, analyte concentration, and technique used for final detection whilst higher preconcentration can be achieved under adequate experimental conditions (time of sample loading, sorbent mass, volume of eluent) [120]. To accumulate Gd-diethylenetriaminepentaacetate (Gd-DTPA) on a stationary phase, the stability of the Gd chelates and their pH dependence are important. Efficiency of Chelex-100, Toyopearl AF Chelate-650 and C18 cartridges loaded with ethylhexylphosphates for the separation of LAs and Gd-DTPA from the water matrix was compared by Hennebrüder et al. [8]. Although the optimum acidity for LA sorption using Chelex 100 and Toyopearl was found to be at $\mathrm{pH} 5.5, \mathrm{Gd}-\mathrm{DTPA}$ retention is insufficient at this $\mathrm{pH}$ and depends on the complex concentration. However, both ionic LAs and Gd-DTPA are sufficiently retarded (about 70\%) by C18 cartridges loaded with ethylhexylphosphates at $\mathrm{pH} \sim 3$ (the optimum acidity) [8]. Raju et al. [122] performed ICP-MS determination of $\mathrm{Gd}$ and its chelates after preconcentration with weak ion exchange material, Chelex-100; strong cation exchange material, Chromabond SA (SCX); and bis-(2-ethylhexyl)-phosphate (HDEHP) coated reverse phase C18. Of the three examined SPE materials, the HDEHP modified reverse phase $\mathrm{C} 18 \mathrm{SPE}$ was found to be the most efficient, yielding a hundredfold Gd preconcentration for contrast agents, such as Gd-BOPTA, Gd-DTPA, Gd-DOTA, and Gd-BT-DO3A [122]. Lawrence [123] used the LLE technique described by Lawrence and Kamber [124] (Table 4) to preconcentrate LAs in samples collected from the Brisbane River and Moreton Bay. Various preconcentration techniques employed for quantifying $\mathrm{Gd}_{\mathrm{anth}}$ are compared with one another in Table 4 . 
Table 4. Different preconcentration procedures utilized for the separation of the complete set of LAs, including $\mathrm{Gd}_{\mathrm{anth}}$.

\begin{tabular}{|c|c|c|c|c|c|c|c|c|c|}
\hline $\begin{array}{l}\text { Preconcentration } \\
\text { Technique }\end{array}$ & Solid Support & $\begin{array}{c}\text { Complexing or } \\
\text { Immobilizing Agent }\end{array}$ & Instrument & Analyte & $\begin{array}{l}\text { Detection } \\
\text { Limit (ng/L) }\end{array}$ & $\begin{array}{l}\text { Preconcentration } \\
\text { Factor }\end{array}$ & Time (min) & Samples & Reference \\
\hline $\begin{array}{l}\text { Solid phase } \\
\text { extraction (SPE) }\end{array}$ & $\mathrm{C} 18$ & $\begin{array}{l}\text { Bis(2-ethylhexyl) } \\
\text { Hydrogen Phosphate } \\
\text { (HDEHP) and } \\
\text { 2-Ethylhexyl Dihydrogen } \\
\text { Phosphate (H2MEHP) }\end{array}$ & ICP-MS & LAs & - & $200-1000$ & $\begin{array}{c}50-250 \\
\text { Batch method }\end{array}$ & Seawater & [125] \\
\hline $\begin{array}{l}\text { Solid phase } \\
\text { extraction (SPE) }\end{array}$ & $\mathrm{C} 18$ & Ethylhexylphosphates & ICP-MS & LAs & - & 13.33 & Batch method & River water & [8] \\
\hline $\begin{array}{c}\text { Solid phase } \\
\text { extraction (SPE) }\end{array}$ & Chelex-100 & - & ICP-MS & LAs & $0.0012-0.034$ & 100 & $\begin{array}{c}120 \\
\text { Batch method }\end{array}$ & Seawater & [126] \\
\hline $\begin{array}{c}\text { Solid phase } \\
\text { extraction (SPE) }\end{array}$ & Chelex-100 & - & ICP-MS & LAs & $50-560$ & 20 & $\begin{array}{l}\text { Not given } \\
\text { Batch method }\end{array}$ & River water & [8] \\
\hline $\begin{array}{c}\text { Solid phase } \\
\text { extraction (SPE) }\end{array}$ & $\begin{array}{c}\text { NOBIAS } \\
\text { CHELATE PA1 }\end{array}$ & - & HR-ICP-MS & LAs & $\begin{array}{l}0.01-0.82 \\
\mathrm{pmol} / \mathrm{kg}\end{array}$ & $160-200$ & $\begin{array}{c}150 \\
\text { Batch method }\end{array}$ & Seawater & [127] \\
\hline $\begin{array}{l}\text { Countercurrent } \\
\text { chromatography } \\
(\text { CCC) }\end{array}$ & - & $\begin{array}{l}\text { Di-2- ethylhexilphosporic } \\
\text { acid (D2EHPA) }\end{array}$ & ICP-MS & LAs, Gd-DTPA & - & 40 & 25 & River water & [128] \\
\hline $\begin{array}{l}\text { Liquid-liquid } \\
\text { extraction (LLE) }\end{array}$ & - & $\begin{array}{c}\text { HDEHP (phosphoric acid } \\
\text { 2-ethylhexyl } \\
\text { ester -mono and di ester } \\
\text { mixture) }\end{array}$ & ICP-MS & LAs & - & 8 & 12 & Seawater & [124] \\
\hline
\end{tabular}


Given that the concentrations of gadolinium diethylenetriaminepentaacetate (Gd-DTPA) and LAs in river water are mostly lower than the detection limits in quadrupole ICP-MS applying pneumatic nebulization, Hennebrüder et al. [128] developed a countercurrent chromatography (CCC) analytical scheme to enrich the analytes prior to ICP-MS detection (Table 4). The stationary phase was di-2-ethylhexylphosphoric acid (D2EHPA) dissolved in n-decane although the mobile phase was $0.01 \mathrm{M} \mathrm{HNO}_{3}$. The employed CCC analytical results were comparable to those obtained by the preconcentration using SPE. The recovery rates for light and middle LAs (La to Tm) and Gd-DTPA (approximately 100\% and 80\%, respectively) were higher when the CCC scheme was used. Nonetheless, the SPE protocol yielded better recoveries for $\mathrm{Yb}$ and $\mathrm{Lu}(89 \%$ and $84 \%$, respectively). To obtain the same preconcentration factor, the CCC technique required a shorter time frame ( $25 \mathrm{~min}$ for CCC vs. $120 \mathrm{~min}$ for SPE). The substantial SPE advantage that outweighs the disadvantage is its capability to preconcentrate several samples simultaneously [128].

To date, the method of Bau and Dulski [7], which is a slightly modified version of the procedure described by Shabani et al. [125] (Table 4), has been the most popular. Whereas the anthropogenic $\mathrm{Gd}$, which is usually determined from the size of the Gd anomaly, is "bulk anthropogenic Gd", it is actually comprised of various chemical compounds used as MRI contrast agents. Contrary to Gd-DOPA (marketed over the last two decades) with a high complex stability, Gd-DTPA (the first on the market) is quantitatively sorbed to the phosphate ester used in the preconcentration procedure. Therefore, nowadays, the excess anthropogenic Gd determined following the original protocol of Bau and Dulski [7] underestimates the anomalous anthropogenic Gd in aqueous samples [129].

de Campos and Enzweiler [17] obtained the Gd concentration of filtered water samples with and without preconcentration. For the preconcentration of LAs, the procedure of Bau and Dulski [7] was used and the average time interval of 4-5 days was considered between the sampling (plus filtering and acidifying) and preconcentration. Interestingly, on average, the result obtained after preconcentration was $40 \%$ lower than that determined without this step. In another experiment, they preconcentrated LAs on the same day of sampling and the Gd content was determined by direct measurement in the filtrate, in the preconcentrated sample, and also in the chromatographic effluent (the sample percolated the SPE cartridge). Whilst the preconcentrated sample contained as low as $5 \%$ of the Gd concentration determined by direct analysis of the water sample, the chromatographic effluent sample accounted for $95 \%$ of it. The low Gd recovery in the eluate was attributed to incomplete dissociation of the paramagnetic Gd chelates in the short period of time between the $\mathrm{pH}$ adjustment of the filtered sample and performing the preconcentration. The unsatisfactory recovery of the dissolved anthropogenic Gd obtained indicates that the original protocol of Bau and Dulski [7] deserves further investigation and other reported anomalous Gd values $[9,10,24,130]$ based on the same method might be underestimated [129].

To preconcentrate low LA concentrations of mussel shells and improve the decomposition of different contrast agents, Merschel and Bau [129] adjusted the method of Bau and Dulski [7] by adding approximately $20 \mathrm{~mL}$ of $30 \% \mathrm{H}_{2} \mathrm{O}_{2}$ per $1 \mathrm{~L}$ of sample prior to passing the sample solution through an ion exchange column.

\subsection{Speciation of $G d-C A s$}

It is vital to monitor $\mathrm{Gd}$ species rather than the total $\mathrm{Gd}$ concentrations to further investigate the anomalous $\mathrm{Gd}_{\mathrm{anth}}$ and obtain more information about the processes and mechanisms resulting in $\mathrm{Gd}$ retention in organisms [97]. However, it is extremely challenging and likely impossible due to their low concentrations. Hence, a preconcentration step is occasionally inevitable.

A range of speciation techniques for the determination of different Gd-CAs in biological and environmental samples are compared in Table 5. With its simple quantitation approaches, ICP-MS is a sensitive, multielemental technique for the investigation of the overall metal content of various matrices. Nevertheless, all species data will be lost during atomization in the ICP. An effective strategy to regain such information is the hyphenation of separation techniques with ICP [131]. Although reversed phase 
chromatography (RP-HPLC) accounts for only very little retention for polar compounds, Mazzucotelli et al. [132] separated one contrast agent and several degradation products using RP-HPLC/ICP-MS. Moreover, size exclusion chromatography (SEC) was used with ICP-MS to separate free $\mathrm{Gd}^{3+}$ from Gd complexes and Gd adducts; however, the size differences between the individual Gd chelates are too small for effective SEC separation [133,134]. Ion chromatography (IC) $[131,135]$, time-resolved luminescence (TRL) detector [136], and direct fluorescence [137] are also utilized for the separation of Gd species. Künnemeyer et al. [138] indicated a high separation efficiency of hydrophilic interaction chromatography (HILIC) for ionic and polar compounds by the determination of contrast agents in blood plasma using HILIC hyphenated to electrospray ionization mass spectrometry (ESI-MS). Since then, HILIC was applied in several scientific studies to analyze biological and environmental samples using zwitterionic, diol, and unboned silica-based stationary phases. Although ESI-MS and ICP-OES (inductively coupled plasma-optical emission spectroscopy) are other potential detection systems [138-141], the hyphenation of HILIC with ICP-MS has proven to be a powerful technique with the best performance for the determination of Gd-CAs, irrespective of aqueous solutions with quite high organic contents in HILIC [142-148]. Lindner et al. [148] employed HILIC-ICP-MS in an optimized speciation method and directly determined Gd-BT-DO3A, Gd-DOTA, and Gd- BOPTA in Berlin tap water, which have been previously found in surface waters of Berlin. By utilizing a sector field-based ICP-MS in the low-resolution mode and employing an ultra-sonic nebulization, Birka et al. [149] accomplished further improvements in sensitivities and decreased the detection limits for single species down to $0.9 \mathrm{ng} / \mathrm{L}$, allowing the performance of speciation analysis in drinking water (Table 5). The analytical results of anthropogenic Gd speciation in aqueous samples are listed in Table 6. 
Table 5. Speciation analysis for the determination of different Gd-CAs in biological and environmental samples.

\begin{tabular}{|c|c|c|c|c|c|}
\hline Sample & Gd/Gd-CAs & Preconcentration/Separation & Instrument & LOD & Reference \\
\hline Urine and hair & Gd, Gd-DTPA & $\begin{array}{l}\text { SE separation: } 20 \mathrm{mmol} / \mathrm{L}(\mathrm{pH}=7.4) \text { of Tris- } \mathrm{HCl} \text { buffer } \\
\text { solutions was applied as eluents for separation of } \mathrm{Gd}^{3+} \\
\text { and Gd-DTPA standard solutions. }\end{array}$ & SEC-ICP-MS & $3500 \mathrm{ng} / \mathrm{L} \mathrm{Gd}$ & [134] \\
\hline River water (Germany) & Gd, Gd-DTPA & $\begin{array}{l}\text { C18-cartridges were loaded with ethylhexylphosphates } \\
\text { and used for Gd preconcentration. }\end{array}$ & ICP-MS & $200 \mathrm{ng} / \mathrm{L} \mathrm{Gd}$ & [8] \\
\hline Water (A bench-scale test) & Gd, Gd-DTPA, Gd-BT-DO3A & $\begin{array}{l}\text { The chelates were separated using a Metrosep A Supp 3- } \\
250 / 4.6 \text { anion separation column, while analysis of the } \\
\text { displaced } \mathrm{Gd}^{3+} \text { was carried out on a Nucleosil } 5 \\
\text { SA-125/4.0 cation separation column using a } \\
\text { 2-hydroxyisobutyric acid eluent. }\end{array}$ & IC-ICP-MS & - & [135] \\
\hline Blood plasma & $\begin{array}{l}\text { Gd-DTPA, Gd-BOPTA, } \\
\text { Gd-DTPA-BMA, Gd-DOTA, } \\
\text { Gd-BT-DO3A }\end{array}$ & $\begin{array}{l}\text { Separation of Gd chelates was carried out using a } \\
\text { ZIC-HILIC column. For separations, eluent A of the } \\
\text { mobile phase consisted of a solution of } 12.5 \mathrm{mM} \\
\text { ammonium formate and } 12.5 \mathrm{mM} \text { formic acid in a } \\
\text { mixture of } 76 / 24 \text { purified water/acetonitrile (pH of } 3.75) \text {. } \\
\text { Eluent B consisted of a solution of } 12.5 \mathrm{mM} \text { ammonium } \\
\text { formate and } 12.5 \mathrm{mM} \text { formic acid in a mixture of } 76 / 24 \\
\text { acetonitrile/water. }\end{array}$ & HILIC-ESI-MS & 100 to $1000 \mathrm{nmol} / \mathrm{L} \mathrm{Gd}$ & [138] \\
\hline Blood serum & $\begin{array}{l}\text { Gd-DTPA, Gd-BOPTA, } \\
\text { Gd-DOTA, Gd-HP-DO3A, } \\
\text { Gd-DTPA-BMA, } \\
\text { Gd-DTPA-BMEA }\end{array}$ & $\begin{array}{l}\text { Chromatographic separation was performed using a } \\
\text { column suitable for the retention of hydrophilic polar } \\
\text { compounds with isocratic elution. The mobile phase } \\
\text { solution consisted of } 10 \mathrm{mM} \text { ammonium acetate with } 0 \text {, } \\
0.5,1,2,3 \text { and } 5 \% \text { acetonitrile (pH } 7.0 \text { to } 7.4 \text { ). }\end{array}$ & HPLC-ICP-OES & 8000 to $35,000 \mathrm{ng} / \mathrm{L} \mathrm{Gd}$ & [140] \\
\hline $\begin{array}{l}\text { Hospital effluent, WWTP } \\
\text { samples collected at different } \\
\text { purification steps (Germany) }\end{array}$ & $\begin{array}{l}\text { Gd-DTPA, Gd-BOPTA, } \\
\text { Gd-DTPA-BMA, Gd-DOTA, } \\
\text { Gd-BT-DO3A }\end{array}$ & $\begin{array}{l}\text { The Gd contrast agents were separated using a } \\
\text { zwitterionic ZIC-HILIC column. The mobile phase } \\
\text { consisted of a solution of } 12.5 \mathrm{mM} \text { ammonium formate } \\
\text { and } 12.5 \mathrm{mM} \text { formic acid in } 76 / 24 \text { acetonitrile/purified } \\
\text { water ( } \mathrm{pH} \text { of } 3.75 \text { ). }\end{array}$ & HILIC-ICP-MS & $1.0 \mathrm{nmol} / \mathrm{L} \mathrm{Gd}$ & [142] \\
\hline $\begin{array}{l}\text { River water, lake water, } \\
\text { WWTP influent and effluent } \\
\text { (Germany) }\end{array}$ & $\begin{array}{l}\text { Gd-DTPA, Gd-BOPTA, } \\
\text { Gd-DTPA-BMA, Gd-DOTA, } \\
\text { Gd-BT-DO3A }\end{array}$ & $\begin{array}{l}\text { By the surface evaporation technique, water samples } \\
\text { were concentrated to approximately 1:10 of the total } \\
\text { volume without boiling. The Gd contrast agents were } \\
\text { separated using a zwitterionic HILIC (ZIC-HILIC) } \\
\text { column. The optimized mobile phase consisted of } 20 \\
\text { mmol/L ammonium acetate in } 60 / 40 \text { acetonitrile/water } \\
\text { (pH 5.8). }\end{array}$ & HILIC-ICP-MS & $22 \pm 5 \mathrm{ng} / \mathrm{L} \mathrm{Gd}$ & [143] \\
\hline
\end{tabular}


Table 5. Cont

\begin{tabular}{|c|c|c|c|c|c|}
\hline Sample & Gd/Gd-CAs & Preconcentration/Separation & Instrument & LOD & Reference \\
\hline $\begin{array}{l}\text { Influent and effluent of a } \\
\text { WWTP (Germany) }\end{array}$ & $\begin{array}{l}\text { Gd-DTPA, Gd-BOPTA, } \\
\text { Gd-DTPA-BMA, Gd-DOTA, } \\
\text { Gd-BT-DO3A }\end{array}$ & $\begin{array}{l}\text { ZIC-HILIC stationary phase was used for analysis of } \\
\text { MRI contrast agents. In isocratic mode, the mobile phase } \\
\text { consisted of a solution of } 50 \mathrm{mM} \text { aqueous ammonium } \\
\text { formate and acetonitrile ( } \mathrm{pH} \text { of } 3.75 \text { ) }\end{array}$ & HILIC-ICP-SFMS & $130 \mathrm{ng} / \mathrm{L} \mathrm{Gd}$ & [144] \\
\hline Surface water (Germany) & $\begin{array}{l}\text { Gd-DTPA, Gd-BOPTA, } \\
\text { Gd-DOTA, Gd-BT-DO3A }\end{array}$ & $\begin{array}{l}\text { Separation of the Gd complexes was carried out in } \\
\text { isocratic mode using an Accucore HILIC column with } \\
\text { solid core particles. The mobile phase consisted of } \\
50 \text { mmol/L aqueous ammonium formate set to pH } 3.75 \\
\text { with formic acid and acetonitrile. }\end{array}$ & HILIC-ICP-SFMS & 80 to $100 \mathrm{pmol} / \mathrm{L} \mathrm{Gd}$ & {$[145]$} \\
\hline Teltow channel (Germany) & $\begin{array}{l}\text { Gd-DTPA, Gd-BOPTA, } \\
\text { Gd-DTPA-BMA, Gd-DOTA, } \\
\text { Gd-BT-DO3A }\end{array}$ & $\begin{array}{l}\text { To preconcentrate the contrast agents, samples were } \\
\text { evaporated with IR light by soft heating to a fraction of } \\
\text { about } 1: 20 \text {. The contrast agents were separated in } \\
\text { isocratic mode using a ZIC-HILIC column. The mobile } \\
\text { phase consisted of } 20 \mathrm{mmol} / \mathrm{L} \text { ammonium acetate in } \\
65 / 35 \text { acetonitrile/water (pH 7.3). }\end{array}$ & HILIC-ICP-MS & $51 \pm 11 \mathrm{ng} / \mathrm{L} \mathrm{Gd}$ & [146] \\
\hline Tap water (Germany) & $\begin{array}{l}\text { Gd-DTPA, Gd-BOPTA, } \\
\text { Gd-DTPA-BMA, Gd-DOTA, } \\
\text { Gd-BT-DO3A }\end{array}$ & $\begin{array}{l}\text { In an isocratic mode, the Gd complexes were separated } \\
\text { using a zwitterionic } \mathrm{ZIC} \text {-cHILIC column. The mobile } \\
\text { phase consisted of } 10 \mathrm{mmol} / \mathrm{L} \text { ammonium acetate in } \\
69 / 31 \text { acetonitrile/water (pH 5.0). }\end{array}$ & HILIC-ICP-MS & 1.4 to $3.5 \mathrm{ng} / \mathrm{L} \mathrm{Gd}$ & {$[148]$} \\
\hline $\begin{array}{l}\text { Samples from waterworks } \\
\text { (Germany) }\end{array}$ & $\begin{array}{l}\text { Gd-DTPA, Gd-DOTA, } \\
\text { Gd-BT-DO3A }\end{array}$ & $\begin{array}{l}\text { An YMC-Triart diol HILIC column was used while the } \\
\text { mobile phase consisted of } 50 \mathrm{mmol} / \mathrm{L} \text { aqueous } \\
\text { ammonium formate (pH 3.7) and acetonitrile in isocratic } \\
\text { mode. }\end{array}$ & HILIC-ICP-MS & 8 to $14 \mathrm{pmol} / \mathrm{L} \mathrm{Gd}$ & [149] \\
\hline
\end{tabular}


Table 6. Concentration of various Gd-based contrast agents in environmental samples. Total Gd was determined by means of ICP-MS.

\begin{tabular}{|c|c|c|c|c|c|c|c|c|c|c|}
\hline Sample & Filtration & Gd-DTPA & Gd-BT-DO3A & Gd-BOPTA & Gd-DOTA & $\Sigma$ Gd Species & Total Gd & Instrument & LOD & Reference \\
\hline $\begin{array}{l}\text { Hospital effluent, } \\
\text { Germany }\end{array}$ & $0.45 \mu \mathrm{m}$ & - & $\begin{array}{l}<\text { D.L. }{ }^{1}-23.1 \\
\text { nmol } / \mathrm{L}\end{array}$ & - & - & $\begin{array}{l}<\text { D.L. }-23.1 \\
\text { nmol } / \mathrm{L}\end{array}$ & $0.5-27.9 \mathrm{nmol} / \mathrm{L}$ & HILIC-ICP-MS & $1.0 \mathrm{nmol} / \mathrm{L} \mathrm{Gd}$ & [142] \\
\hline $\begin{array}{l}\text { WWTP samples } \\
\text { collected at different } \\
\text { purification steps, } \\
\text { Germany }\end{array}$ & $0.45 \mu \mathrm{m}$ & - & $2.0-7.4 \mathrm{nmol} / \mathrm{L}$ & $1.1-1.2 \mathrm{nmol} / \mathrm{L}$ & $1.8-2.1 \mathrm{nmol} / \mathrm{L}$ & $2.0-10.6 \mathrm{nmol} / \mathrm{L}$ & $1.8-13.6 \mathrm{nmol} / \mathrm{L}$ & HILIC-ICP-MS & $1.0 \mathrm{nmol} / \mathrm{L} \mathrm{Gd}$ & [142] \\
\hline $\begin{array}{c}\text { Spree River } \\
\text { (Dämeritzsee), } \\
\text { Germany }\end{array}$ & $0.45 \mu \mathrm{m}$ & - & $12.0 \mathrm{ng} / \mathrm{L} \mathrm{Gd}$ & - & - & $12.0 \mathrm{ng} / \mathrm{L} \mathrm{Gd}$ & $15.0 \mathrm{ng} / \mathrm{L} \mathrm{Gd}$ & HILIC-ICP-MS & $22 \pm 5 \mathrm{ng} / \mathrm{L} \mathrm{Gd}$ & [143] \\
\hline $\begin{array}{l}\text { Lake Wannsee, } \\
\text { Germany }\end{array}$ & $0.45 \mu \mathrm{m}$ & $106.0 \mathrm{ng} / \mathrm{L} \mathrm{Gd}$ & $184.0 \mathrm{ng} / \mathrm{L} \mathrm{Gd}$ & $12.0 \mathrm{ng} / \mathrm{L} \mathrm{Gd}$ & $110.0 \mathrm{ng} / \mathrm{L} \mathrm{Gd}$ & $412.0 \mathrm{ng} / \mathrm{L} \mathrm{Gd}$ & $436.0 \mathrm{ng} / \mathrm{L} \mathrm{Gd}$ & HILIC-ICP-MS & $22 \pm 5 \mathrm{ng} / \mathrm{L} \mathrm{Gd}$ & [143] \\
\hline $\begin{array}{c}\text { Havel River } \\
\text { (Jungfernsee), } \\
\text { Germany }\end{array}$ & $0.45 \mu \mathrm{m}$ & $54.0 \mathrm{ng} / \mathrm{L} \mathrm{Gd}$ & $89.0 \mathrm{ng} / \mathrm{L} \mathrm{Gd}$ & - & $50.0 \mathrm{ng} / \mathrm{L} \mathrm{Gd}$ & $194.0 \mathrm{ng} / \mathrm{L} \mathrm{Gd}$ & $215.0 \mathrm{ng} / \mathrm{L} \mathrm{Gd}$ & HILIC-ICP-MS & $22 \pm 5 \mathrm{ng} / \mathrm{L} \mathrm{Gd}$ & [143] \\
\hline $\begin{array}{l}\text { WWTP influent, } \\
\text { Germany }\end{array}$ & $0.45 \mu \mathrm{m}$ & $29.0 \mathrm{ng} / \mathrm{L} \mathrm{Gd}$ & $36.0 \mathrm{ng} / \mathrm{L} \mathrm{Gd}$ & - & $34.0 \mathrm{ng} / \mathrm{L} \mathrm{Gd}$ & $99.0 \mathrm{ng} / \mathrm{L} \mathrm{Gd}$ & $122.0 \mathrm{ng} / \mathrm{L} \mathrm{Gd}$ & HILIC-ICP-MS & $22 \pm 5 \mathrm{ng} / \mathrm{L} \mathrm{Gd}$ & [143] \\
\hline $\begin{array}{l}\text { WWTP effluent, } \\
\text { Germany }\end{array}$ & $0.45 \mu \mathrm{m}$ & $27.0 \mathrm{ng} / \mathrm{L} \mathrm{Gd}$ & $34.0 \mathrm{ng} / \mathrm{L} \mathrm{Gd}$ & - & $36.0 \mathrm{ng} / \mathrm{L} \mathrm{Gd}$ & $97.0 \mathrm{ng} / \mathrm{L} \mathrm{Gd}$ & 118.0 ng/L Gd & HILIC-ICP-MS & $22 \pm 5 \mathrm{ng} / \mathrm{L} \mathrm{Gd}$ & [143] \\
\hline $\begin{array}{l}\text { Surface water, } \\
\text { Germany }\end{array}$ & $0.2 \mu \mathrm{m}$ & $\begin{array}{c}<\text { D.L. }-2.1 \\
\text { nmol/L }\end{array}$ & $\begin{array}{c}<\text { D.L. }-3.6 \\
\text { nmol/L }\end{array}$ & - & $\begin{array}{c}<\text { D.L. }-0.8 \\
\text { nmol/L }\end{array}$ & $\begin{array}{c}<\text { D.L. }-6.4 \\
\text { nmol/L }\end{array}$ & $0.6-7.4 \mathrm{nmol} / \mathrm{L}$ & HILIC-ICP-SFMS & $\begin{array}{c}80-100 \mathrm{pmol} / \mathrm{L} \\
\mathrm{Gd}\end{array}$ & [145] \\
\hline $\begin{array}{l}\text { WWTP effluent, } \\
\text { Germany }\end{array}$ & $0.2 \mu \mathrm{m}$ & $1.6 \mathrm{nmol} / \mathrm{L}$ & $2.7 \mathrm{nmol} / \mathrm{L}$ & - & $0.6 \mathrm{nmol} / \mathrm{L}$ & $4.8 \mathrm{nmol} / \mathrm{L}$ & $6.5 \mathrm{nmol} / \mathrm{L}$ & HILIC-ICP-SFMS & $\begin{array}{c}80-100 \mathrm{pmol} / \mathrm{L} \\
\mathrm{Gd}\end{array}$ & [145] \\
\hline $\begin{array}{l}\text { Teltow channel, } \\
\text { Germany }\end{array}$ & $0.2 \mu \mathrm{m}$ & - & $\begin{array}{c}18.0-471.0 \mathrm{ng} / \mathrm{L} \\
\mathrm{Gd}\end{array}$ & - & $\begin{array}{c}16.0-456.0 \mathrm{ng} / \mathrm{L} \\
\mathrm{Gd}\end{array}$ & $\begin{array}{c}34.0-926.0 \mathrm{ng} / \mathrm{L} \\
\mathrm{Gd}\end{array}$ & $\begin{array}{c}50.0-990.0 \mathrm{ng} / \mathrm{L} \\
\mathrm{Gd}\end{array}$ & HILIC-ICP-MS & 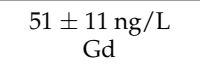 & [146] \\
\hline Tap water, Germany & $0.2 \mu \mathrm{m}$ & - & $\begin{array}{l}<\text { D.L. }-17.6 \\
\text { ng/L Gd }\end{array}$ & $\begin{array}{l}\text { <D.L. -11.7 } \\
\text { ng/L Gd }\end{array}$ & $\begin{array}{l}<\text { D.L. }-19.2 \\
\text { ng/L Gd }\end{array}$ & $\begin{array}{l}<\text { D.L. }-48.5 \\
\text { ng/L Gd }\end{array}$ & $\begin{array}{c}2.0-57.0 \mathrm{ng} / \mathrm{L} \\
\mathrm{Gd}\end{array}$ & HILIC-ICP-MS & $1.4-3.5 \mathrm{ng} / \mathrm{L} \mathrm{Gd}$ & [148] \\
\hline $\begin{array}{l}\text { Surface water, } \\
\text { Germany }\end{array}$ & $0.2 \mu \mathrm{m}$ & $\begin{array}{c}88.0-161.0 \\
\mathrm{pmol} / \mathrm{L}\end{array}$ & $\begin{array}{c}<\text { D.L. }-49.0 \\
\text { pmol/L }\end{array}$ & - & $\begin{array}{l}<\text { D.L. }-85.0 \\
\mathrm{pmol} / \mathrm{L}\end{array}$ & $\begin{array}{c}88.0-262.0 \\
\mathrm{pmol} / \mathrm{L}\end{array}$ & $\begin{array}{c}82.0-307.0 \\
\mathrm{pmol} / \mathrm{L}\end{array}$ & HILIC-ICP-MS & 8-14 pmol/L & [149] \\
\hline $\begin{array}{l}\text { Drinking water, } \\
\text { Germany }\end{array}$ & $0.2 \mu \mathrm{m}$ & $\begin{array}{c}82.0-159.0 \\
\mathrm{pmol} / \mathrm{L}\end{array}$ & $<$ D.L. & - & $\begin{array}{l}<\text { D.L. }-74.0 \\
\mathrm{pmol} / \mathrm{L}\end{array}$ & $\begin{array}{c}82.0-196.0 \\
\mathrm{pmol} / \mathrm{L}\end{array}$ & $\begin{array}{c}100.0-298.0 \\
\mathrm{pmol} / \mathrm{L}\end{array}$ & HILIC-ICP-MS & 8-14 $\underset{\mathrm{Gd}}{\mathrm{pmol} / \mathrm{L}}$ & [149] \\
\hline
\end{tabular}




\subsection{Fractionation of $G d_{\text {anth }}$}

Generally, the mobility and bioavailability of LAs are governed by several factors, such as temperature, $\mathrm{pH}$, as well as the concentration and type of organic and inorganic ligands [32,63]. According to Wells and Wells [150], nitrates, chlorides, and sulfates of LAs are soluble; however, their hydroxides, carbonates, and phosphates are insoluble. In river and estuarine waters, it is documented that $\mathrm{pH}$, colloids, and salinity control the LA fractionation [32]. Researchers have generally used $0.2-0.45 \mu \mathrm{m}$ membrane filters to obtain the so-called "dissolved" fraction $(<0.4 \mu \mathrm{m})$. Both Elderfield et al. [151] and Sholkovitz [152] indicated that river colloids that can pass through the conventional membranes account for a large proportion of the "dissolved" LA pool. Hence, keeping the filtration protocol in mind is vital for the comparison of results [11].

Acidification experiments can be carried out to assess $\mathrm{Gd}$ fractionation [7,153]. In these experiments, the concentration of the 'dissolved' LAs (comprised of truly dissolved and colloidal LAs) is determined from the samples filtered through a $0.2 \mu \mathrm{m}$ membrane filter prior to acidification. However, the sum of the dissolved plus the acid-soluble particulate LAs is detected from the samples acidified to $\mathrm{pH} 2$ before $0.2 \mu \mathrm{m}$ filtration. The results obtained from acidification experiments suggest [7,153]: (1) A difference between the speciation of $\mathrm{Gd}_{\mathrm{anth}}$ in contaminated waters and the speciation of geogenic LAs in non-contaminated waters; (2) the presence of the excess Gd in the 'dissolved' LA fraction $(<0.2 \mu \mathrm{m})$ rather than the acid—soluble particulate fraction; and (3) negligible particle reactivity of the anomalous $\mathrm{Gd}$ in water resources.

Filtration experiments are helpful in deciphering $\mathrm{Gd}$ fractionation as well. In addition to the $0.2 \mu \mathrm{m}$ filtration, Kulaksız and Bau [24] passed an unacidified sample through a Vivaflow 50 unit (10 kDa MWCO) before preconcentration. LA concentrations $<0.2 \mu \mathrm{m}$ were referred to as 'dissolved' (i.e., the sum of truly dissolved LAs and LA bound to colloids), while concentrations in the $<10 \mathrm{kDa}$ LA pool were considered as "truly dissolved". Thus, the difference between the truly dissolved and the dissolved LA values explains the colloid-bound LA concentration. The result of the filtration experiment [24] indicates that the $\mathrm{Gd}_{\mathrm{anth}}$ is not particle-reactive and exclusively present in the truly dissolved LA pool $(<10 \mathrm{kDa})$, which is in accordance with the results of the acidification experiment carried out by Bau and Dulski [7].

\section{5. $G d_{\text {anth }}$ in the Influent and Effluent of Wastewater Treatment Plants}

The temporal variations in Gd values in influents and effluents depend on the dynamics between the percentage of the inhabitants undergoing MRI exams, the amount of Gd-CAs administered daily, the time of application and excretion of the contrast agents, and transport, dilution, and retention times in WWTPs. Because the predominant MRI scans with intravenous injection of Gd-CAs are performed in working days (i.e., between Monday and Friday) [144,154,155], Gd contents in both influents and effluents are weekday dependent [1]. In regions with no hospitals and limited access to the health system, anthropogenic Gd can also be determined since there might be people taking the exam in neighboring cities, resulting in the release of the stable Gd complexes when they get back home [16]. Möller et al. [3] attributed the considerable difference between the $\mathrm{Gd}_{\mathrm{anth}}$ flux of WWTP effluents and the daily administered quantity of paramagnetic Gd chelates in Prague's hospitals to the excretion of $10 \%$ to $20 \%$ of the total Gd-CAs administered per day somewhere outside Prague. The discharge of treated wastewater into nearby natural water bodies can also play a significant role in a positive $\mathrm{Gd}$ anomaly in the LA pattern of water resources situated kilometers away from the point source. More than $50 \mathrm{~km}$ downstream of a WWTP source, $\mathrm{Gd}_{\text {anth }}$ (a tracer of treated wastewater) was easily detected in the receiving waters [2]. In areas where there are no major hospitals running MRI scans, enhanced $\mathrm{Gd}_{\mathrm{anth}}$ contents in surface water resources with no connection to sewage treatment plants indicate an imperfect sewer system (uncontrolled dispersion by gutters and leaking sewers) as well [3]. Measured Gd values in wastewaters with $\mathrm{Gd}_{\text {anth }}$ are provided in Table 7. 
Table 7. Total Gd concentrations and Gd anomalies reported in wastewaters and polluted aqueous samples. The subscript, SN, denotes the normalization to the Gd content in the continental crust (regularly PAAS was used) and the superscript * denotes the natural background value.

\begin{tabular}{|c|c|c|c|c|c|c|c|c|}
\hline Sample & Study area & Filtration & Acidification & Instrument & Detection Limit & Gd & $\mathrm{Gd}_{\mathrm{SN}} / \mathrm{Gd}_{\mathrm{SN}}^{*}$ & Reference \\
\hline \multirow[t]{6}{*}{ WWTP influent } & GAW, South Korea & $0.2 \mu \mathrm{m}$ & $\mathrm{pH}=2.0$ & Q-ICP-MS & - & $2040.0 \mathrm{pmol} / \mathrm{L}$ & $111.0^{1}$ & [13] \\
\hline & WSW, South Korea & $0.2 \mu \mathrm{m}$ & $\mathrm{pH}=2.0$ & Q-ICP-MS & - & $126.0 \mathrm{pmol} / \mathrm{L}$ & $4.2^{1}$ & [13] \\
\hline & TAW, South Korea & $0.2 \mu \mathrm{m}$ & $\mathrm{pH}=2.0$ & Q-ICP-MS & - & $3724.0 \mathrm{pmol} / \mathrm{L}$ & $297.0^{1}$ & [13] \\
\hline & JNW, South Korea & $0.2 \mu \mathrm{m}$ & $\mathrm{pH}=2.0$ & Q-ICP-MS & - & $815.0 \mathrm{pmol} / \mathrm{L}$ & $66.1^{1}$ & [13] \\
\hline & AYW, South Korea & $0.2 \mu \mathrm{m}$ & $\mathrm{pH}=2.0$ & Q-ICP-MS & - & $508.0 \mathrm{pmol} / \mathrm{L}$ & $34.6^{1}$ & [13] \\
\hline & Prague, Czech Republic & $0.2 \mathrm{~mm}$ & $\mathrm{pH}=2.0$ & ICP-MS & - & $437.0 \mathrm{nmol} / \mathrm{m}^{3}$ & $35.0^{1}$ & [3] \\
\hline \multirow[t]{15}{*}{ WWTP effluent } & GAW, South Korea & $0.2 \mu \mathrm{m}$ & $\mathrm{pH}=2.0$ & Q-ICP-MS & - & $321.0 \mathrm{pmol} / \mathrm{L}$ & $81.0^{1}$ & [13] \\
\hline & WSW, South Korea & $0.2 \mu \mathrm{m}$ & $\mathrm{pH}=2.0$ & Q-ICP-MS & - & $272.0 \mathrm{pmol} / \mathrm{L}$ & $56.7^{1}$ & [13] \\
\hline & TAW, South Korea & $0.2 \mu \mathrm{m}$ & $\mathrm{pH}=2.0$ & Q-ICP-MS & - & $1286.0 \mathrm{pmol} / \mathrm{L}$ & $271.0^{1}$ & [13] \\
\hline & JNW, South Korea & $0.2 \mu \mathrm{m}$ & $\mathrm{pH}=2.0$ & Q-ICP-MS & - & $786.0 \mathrm{pmol} / \mathrm{L}$ & $186.0^{1}$ & [13] \\
\hline & AYW, South Korea & $0.2 \mu \mathrm{m}$ & $\mathrm{pH}=2.0$ & Q-ICP-MS & - & $676.0 \mathrm{pmol} / \mathrm{L}$ & $147.0^{1}$ & [13] \\
\hline & GPW, South Korea & $0.2 \mu \mathrm{m}$ & $\mathrm{pH}=2.0$ & Q-ICP-MS & - & $760.0 \mathrm{pmol} / \mathrm{L}$ & $198.0^{1}$ & [13] \\
\hline & São Paulo State, Brazil & $0.22 \mu \mathrm{m}$ & $\mathrm{pH}=1.8-2.0$ & ICP-MS & $1.4 \mathrm{ng} / \mathrm{kg}$ & $86.0 \mathrm{ng} / \mathrm{kg}$ & $9.5^{2}$ & [17] \\
\hline & Brisbane, Australia & $0.22 \mu \mathrm{m}$ & $\mathrm{pH}=1.5$ & ICP-MS & $480 \mathrm{fmol} / \mathrm{L}$ & $119.6-1795.0 \mathrm{pmol} / \mathrm{kg}$ & $9.0-99.0^{3}$ & [16] \\
\hline & Bremen-Seehausen, Germany & $0.45 \mu \mathrm{m}$ & $\mathrm{pH}=1.8-2.0$ & ICP-MS & - & $1673.8 \mathrm{pmol} / \mathrm{L}$ & $169.7^{4}$ & [15] \\
\hline & Tallahassee, USA & Total & $\mathrm{pH}<2$ & ICP-MS & - & $0.12 \mu \mathrm{g} / \mathrm{L}$ & $49.6^{1}$ & [156] \\
\hline & Denver, USA & $0.45 \mu \mathrm{m}$ & $\mathrm{pH}<2$ & ICP-MS & - & $0.14 \mu \mathrm{g} / \mathrm{L}$ & $20.0^{1}$ & [156] \\
\hline & Boulder, USA & $0.45 \mu \mathrm{m}$ & $\mathrm{pH}<2$ & ICP-MS & - & $0.068 \mu \mathrm{g} / \mathrm{L}$ & $62.7^{1}$ & [156] \\
\hline & Berlin, Germany & $0.2 \mu \mathrm{m}$ & $\mathrm{pH}=2.0$ & ICP-MS & $0.01-0.1 \mathrm{pg} / \mathrm{mL}$ & $201.0-7480.0 \mathrm{pmol} / \mathrm{kg}$ & 64-2014 ${ }^{1}$ & [153] \\
\hline & Prague, Czech Republic & $0.2 \mathrm{~mm}$ & $\mathrm{pH}=2.0$ & ICP-MS & - & $253.0-278.0 \mathrm{nmol} / \mathrm{m}^{3}$ & $55.4-61.7^{3}$ & [3] \\
\hline & Berlin, Germany & $0.2 \mathrm{~mm}$ & $\mathrm{pH}=2.0$ & ICP-MS & - & $7087 \mathrm{pmol} / \mathrm{kg}$ & $1681^{1}$ & [7] \\
\hline \multirow[t]{9}{*}{ River water } & Neuse River, USA & $0.45 \mu \mathrm{m}$ & - & Q-ICP-MS & - & $25.4-342.0 \mathrm{pg} / \mathrm{g}$ & $1.1-4.0^{5}$ & [19] \\
\hline & Han River, South Korea & $0.2 \mu \mathrm{m}$ & $\mathrm{pH}=2.0$ & Q-ICP-MS & - & $45.9-209.0 \mathrm{pmol} / \mathrm{L}$ & $1.6-8.2^{1}$ & [13] \\
\hline & Gyeungan stream, South Korea & $0.2 \mu \mathrm{m}$ & $\mathrm{pH}=2.0$ & Q-ICP-MS & - & $141.0 \mathrm{pmol} / \mathrm{L}$ & $8.7^{1}$ & [13] \\
\hline & Tan stream, South Korea & $0.2 \mu \mathrm{m}$ & $\mathrm{pH}=2.0$ & Q-ICP-MS & - & $322.0 \mathrm{pmol} / \mathrm{L}$ & $3.6^{1}$ & [13] \\
\hline & Jungnang stream, South Korea & $0.2 \mu \mathrm{m}$ & $\mathrm{pH}=2.0$ & Q-ICP-MS & - & $308.0 \mathrm{pmol} / \mathrm{L}$ & $7.4^{1}$ & [13] \\
\hline & Gulpo stream, South Korea & $0.2 \mu \mathrm{m}$ & $\mathrm{pH}=2.0$ & Q-ICP-MS & - & $573.0 \mathrm{pmol} / \mathrm{L}$ & $34.8^{1}$ & [13] \\
\hline & Anhumas Creek, Brazil & $0.22 \mu \mathrm{m}$ & $\mathrm{pH}=1.8-2.0$ & ICP-MS & $1.4 \mathrm{ng} / \mathrm{kg}$ & $13.0-207.0 \mathrm{ng} / \mathrm{kg}$ & $1.1-86.7^{2}$ & [17] \\
\hline & Havel River, Germany & $0.2 \mu \mathrm{m}$ & $\mathrm{pH}=1.8-2.0$ & ICP-MS & - & $3136 \mathrm{pmol} / \mathrm{L}$ & $644.0^{2}$ & [10] \\
\hline & Rhine River, Germany & $0.2 \mu \mathrm{m}$ & $\mathrm{pH}=1.8-2.0$ & ICP-MS & - & $11.8-188.0 \mathrm{ng} / \mathrm{kg}$ & $4.4-110.0^{2}$ & [9] \\
\hline
\end{tabular}


Table 7. Cont

\begin{tabular}{|c|c|c|c|c|c|c|c|c|}
\hline Sample & Study area & Filtration & Acidification & Instrument & Detection Limit & Gd & $\mathrm{Gd}_{\mathrm{SN}} / \mathrm{Gd}^{*}{ }_{\mathrm{SN}}$ & Reference \\
\hline & Danube River, Austria & $0.2 \mu \mathrm{m}$ & $\mathrm{pH}=1.8-2.0$ & ICP-MS & - & $48.6 \mathrm{pmol} / \mathrm{L}$ & $2.3^{2}$ & [10] \\
\hline & River Thames, England & $0.2 \mu \mathrm{m}$ & $\mathrm{pH}=1.8-2.0$ & ICP-MS & - & $28 \mathrm{pmol} / \mathrm{L}$ & $2.5^{2}$ & [10] \\
\hline & Weser River, Germany & $0.45 \mu \mathrm{m}$ & $\mathrm{pH}=1.8-2.0$ & ICP-MS & - & $115.7 \mathrm{pmol} / \mathrm{L}$ & $5.4^{4}$ & [15] \\
\hline & Ems River, Germany & $0.45 \mu \mathrm{m}$ & $\mathrm{pH}=1.8-2.0$ & ICP-MS & - & $154.0 \mathrm{pmol} / \mathrm{L}$ & $3.6^{4}$ & [15] \\
\hline & Elbe River, Germany & $0.45 \mu \mathrm{m}$ & $\mathrm{pH}=1.8-2.0$ & ICP-MS & - & $94.8 \mathrm{pmol} / \mathrm{L}$ & $5.5^{4}$ & [15] \\
\hline & Susquehanna River, USA & $0.2 \mu \mathrm{m}$ & $\mathrm{pH}=2.1$ & ICP-MS & $0.01-0.1 \mathrm{pg} / \mathrm{mL}$ & $62.6 \mathrm{pmol} / \mathrm{L}$ & $2.2^{1}$ & [18] \\
\hline & Shonai River, Japan & $0.45 \mu \mathrm{m}$ & $\mathrm{pH}=1$ & ICP-MS & $0.027 \mathrm{ng} / \mathrm{L}$ & $8.9 \mathrm{ng} / \mathrm{L}$ & $2.1^{1}$ & [12] \\
\hline & Tenpaku River, Japan & $0.45 \mu \mathrm{m}$ & $\mathrm{pH}=1$ & ICP-MS & $0.027 \mathrm{ng} / \mathrm{L}$ & $14.0 \mathrm{ng} / \mathrm{L}$ & $9.4^{1}$ & [12] \\
\hline & Tone River, Japan & $0.04 \mu \mathrm{m}$ & $\mathrm{pH}<1.5$ & ICP-MS & - & $10.3-58.5 \mathrm{pmol} / \mathrm{kg}$ & $1.6-2.9^{1}$ & [11] \\
\hline & Tama River, Japan & $0.04 \mu \mathrm{m}$ & $\mathrm{pH}<1.5$ & ICP-MS & - & $25.0-155.0 \mathrm{pmol} / \mathrm{kg}$ & $2.2-3.3^{1}$ & [11] \\
\hline & Ara River, Japan & $0.04 \mu \mathrm{m}$ & $\mathrm{pH}<1.5$ & ICP-MS & - & $26.2-66.2 \mathrm{pmol} / \mathrm{kg}$ & $2.7-6.2^{1}$ & [11] \\
\hline & Rokytka creek, Czech Republic & $0.2 \mathrm{~mm}$ & $\mathrm{pH}=2.0$ & ICP-MS & - & $35.7 \mathrm{nmol} / \mathrm{m}^{3}$ & $1.8^{3}$ & [3] \\
\hline & Wupper River, Germany & $0.2 \mu \mathrm{m}$ & $\mathrm{pH}=1.9-2.1$ & ICP-MS & - & $207.0 \mathrm{pmol} / \mathrm{kg}$ & $30.0^{1}$ & [7] \\
\hline & Spree River, Germany & $0.2 \mu \mathrm{m}$ & $\mathrm{pH}=1.9-2.1$ & ICP-MS & - & $43.1 \mathrm{pmol} / \mathrm{kg}$ & $12.4^{1}$ & [7] \\
\hline & Havel River, Germany & $0.2 \mu \mathrm{m}$ & $\mathrm{pH}=1.9-2.1$ & ICP-MS & - & $675 \mathrm{pmol} / \mathrm{L}$ & $126^{2}$ & [7] \\
\hline \multirow[t]{7}{*}{ Seawater } & Bahia Coast, NE Brazil & $0.2 \mu \mathrm{m}$ & $\mathrm{pH}=1.8$ & HR ICP-MS & - & $4.5-12.0 \mathrm{pmol} / \mathrm{kg}$ & $1.0-3.4^{3}$ & [1] \\
\hline & San Francisco Bay, USA & $0.45 \mu \mathrm{m}$ & $\mathrm{pH}=1.8$ & HR ICP-MS & $0.03 \mathrm{pmol} / \mathrm{kg}$ & $14.1-171.4 \mathrm{pmol} / \mathrm{kg}$ & $1.6-3.9^{3}$ & [20] \\
\hline & Weser Estuary, Germany & $0.45 \mu \mathrm{m}$ & $\mathrm{pH}=1.8-2.0$ & ICP-MS & - & $45.1-150.6 \mathrm{pmol} / \mathrm{L}$ & $3.8-7.4^{4}$ & [15] \\
\hline & North Sea & $0.45 \mu \mathrm{m}$ & $\mathrm{pH}=1.8-2.0$ & ICP-MS & - & $11.2-14.1 \mathrm{pmol} / \mathrm{L}$ & $1.6-2.1^{4}$ & [15] \\
\hline & Jade Bay, North Germany & $0.45 \mu \mathrm{m}$ & $\mathrm{pH}=1.8-2.0$ & ICP-MS & - & $17.9 \mathrm{pmol} / \mathrm{L}$ & $1.7^{4}$ & [15] \\
\hline & Nagoya port, Japan & $0.45 \mu \mathrm{m}$ & $\mathrm{pH}=1$ & ICP-MS & $0.027 \mathrm{ng} / \mathrm{L}$ & $2.2 \mathrm{ng} / \mathrm{L}$ & $1.6^{1}$ & [12] \\
\hline & Tokyo Bay, Japan & $0.04 \mu \mathrm{m}$ & $\mathrm{pH}<1.5$ & ICP-MS & - & $8.4-15.4 \mathrm{pmol} / \mathrm{kg}$ & $1.5-2.1^{1}$ & [11] \\
\hline \multirow[t]{2}{*}{ Lake water } & Lake Paranoá, Brazil & $0.2 \mu \mathrm{m}$ & $\mathrm{pH}=1.8-2.0$ & ICP-MS & - & $7.9-35.2 \mathrm{ng} / \mathrm{kg}$ & $18.5-40.9^{5}$ & [157] \\
\hline & Kyjsky pond, Czech Republic & $0.2 \mathrm{~mm}$ & $\mathrm{pH}=2.0$ & ICP-MS & - & $27.6 \mathrm{nmol} / \mathrm{m}^{3}$ & $2.8^{3}$ & [3] \\
\hline \multirow[t]{2}{*}{ Groundwater } & Honokohau Harbor well, Hawaii & $0.45 \mu \mathrm{m}$ & $\mathrm{pH}<2$ & HR-ICP-MS & $0.5-6 \mathrm{pmol} / \mathrm{kg}$ & $192.0 \mathrm{pmol} / \mathrm{kg}$ & $5.1^{1}$ & [21] \\
\hline & Berlin, Germany & $0.2 \mu \mathrm{m}$ & $\mathrm{pH}=2.0$ & ICP-MS & $0.01-0.1 \mathrm{pg} / \mathrm{ml}$ & $110.0-755.0 \mathrm{pmol} / \mathrm{kg}$ & $3.6-53.0^{1}$ & [153] \\
\hline \multirow[t]{3}{*}{ Tap water } & Western Berlin, Germany & $0.2 \mu \mathrm{m}$ & $\mathrm{pH}=1.8-2.0$ & ICP-MS & - & $3.5-115.0 \mathrm{pmol} / \mathrm{L}$ & $1.4-33.7^{2}$ & [10] \\
\hline & London, England & - & - & ICP-MS & - & $12.3 \mathrm{pmol} / \mathrm{L}$ & $1.5^{2}$ & [10] \\
\hline & Berlin-Steglitz, Germany & $0.2 \mu \mathrm{m}$ & $\mathrm{pH}=1.9-2.1$ & ICP-MS & - & $39.8 \mathrm{pmol} / \mathrm{kg}$ & $12.0^{1}$ & [7] \\
\hline
\end{tabular}

${ }^{1} \mathrm{Gd}_{\mathrm{SN}} / \mathrm{Gd}_{\mathrm{SN}}^{*}=\mathrm{Gd}_{\mathrm{SN}} /\left(0.33 \mathrm{Sm}_{\mathrm{SN}}+0.67 \mathrm{~Tb}_{\mathrm{SN}}\right)^{2}$ Calculated using linear regression method ${ }^{3}$ Calculated using the third order polynomial fit ${ }^{4} \mathrm{Gd}_{\mathrm{SN}} / \mathrm{Gd}^{*} \mathrm{SN}=\mathrm{Gd}_{\mathrm{SN}} / 10^{\wedge}\left(2 \operatorname{logSm}-\log _{\mathrm{Nd}}\right)^{5}$ Calculated from $\log \mathrm{Gd}_{\mathrm{SN}}^{*}=\left(4 \log \mathrm{Eu}_{\mathrm{SN}}-\log \mathrm{Nd}_{\mathrm{SN}}\right) / 3$. 
To enhance the settling characteristics of dissolved chemicals and suspended colloids, flocculation with $\mathrm{Fe}^{3+}$ or $\mathrm{Al}^{3+}$ salts is conducted in municipal sewage treatment plants. Since the added trivalent metal ions compete with $\mathrm{Gd}^{3+}$ for the organic ligands, depending on the thermodynamic complex stability, the trivalent metal salts encourage transmetallation (metal exchange) of the MRI Gd chelates and consequently release toxic $\mathrm{Gd}^{3+}[142,158]$. For the retention of organically bound $\mathrm{Gd}$, Möller et al. [3] suggested passing water from filter-beds and then treating it by FeOOH precipitation as a more effective approach than the $\mathrm{FeOOH}$ precipitation alone.

During regular treatment operations at WWTPs, a major proportion of natural dissolved LAs and only a minor fraction of $\mathrm{Gd}$ from anthropogenic sources can be removed, and the $\mathrm{Gd}_{\text {anth }}$ anomaly will consequently be highlighted $[144,159]$. Even with secondary or tertiary treatments (involving organic degradation and disinfection) in WWTPs, Gd-CAs are not expected to be treated owing to the high solubility of the polar or ionic Gd-CAs and the high stability of their complexes. Complexation of anthropogenic $\mathrm{Gd}$ from the MRI diagnostic system with either $\mathrm{Cl}^{-}$or $\mathrm{SO}_{4}^{2-}$ and pronounced positive Gd anomalies in WWTP samples were reported by Song et al. [13]. Given the water treatment methods in the studied WWTPs, i.e., conventional activated sludge process (CASP), cilium nutrient removal (CNR), micro-chip filter (MCF), high class treatment (HCT), modified ludzack ettinger (MLE), and phased Isolation ditch (PID), they are probably not efficient enough for the removal of the $\mathrm{Gd}_{\mathrm{anth}}$ load [13]. Telgmann et al. [144] simulated the aeration tank of a sewage treatment plant by batch experiments and showed that only approximately $10 \%$ of the Gd (Gd-DTPA) was removed during activated sludge treatment in WWTPs. Contrary to coagulation and microfiltration, the removal of $99.85 \%$ of anthropogenic Gd was reported by the reverse osmosis membrane [118].

On a population basis, in 2017, Pedreira et al. [1] calculated a total daily discharge of $11.5 \pm 4.3 \mathrm{~g}$ Gd/d per 100,000 people and $15.5 \pm 3.3 \mathrm{~g} \mathrm{Gd/d}$ per 100,000 people for two WWTPs in Brazil. However, WWTPs in highly populated regions of Berlin were estimated to discharge $5 \mathrm{~g} \mathrm{Gd} / \mathrm{d}$ per 100,000 people from 1997 to 2000 [153], and a WWTP in southeast Queensland had a discharge of $3.3 \mathrm{~g} \mathrm{Gd} / \mathrm{d}$ per 100,000 people [16]. According to the estimation of Lawrence and Bariel [2], WWTPs in less populated areas accommodating approximately 100,000 persons are expected to discharge orders of magnitude lower that accounts for emissions of about $0.9 \mathrm{~g} \mathrm{Gd} / \mathrm{d}$ per 100,000 people. Pedreira et al. [1] explained that although they collected samples when the highest Gd inputs were expected (resulting in maximum values and not true averages), this discrepancy between the Gd emissions calculated for the WWTPs in Brazil and other cities may not be irrelevant to the upward trend of the number of MRI exams over the past 10 years (Figure 4). For instance, between 2007 and 2016, the statistics of MRI exams per 1000 American and Australian inhabitants increased by 32\% and $124 \%$, respectively. In Germany, the number of MRI exams increased from 84 exams /1000 inhabitants in 2007 to 136 exams / 1000 inhabitants in 2015 (Figure 4) [160]. The recent statistics feasibly suggest the need for updating the estimates of Knappe et al. [153] and Lawrence and Bariel [1,2]. 


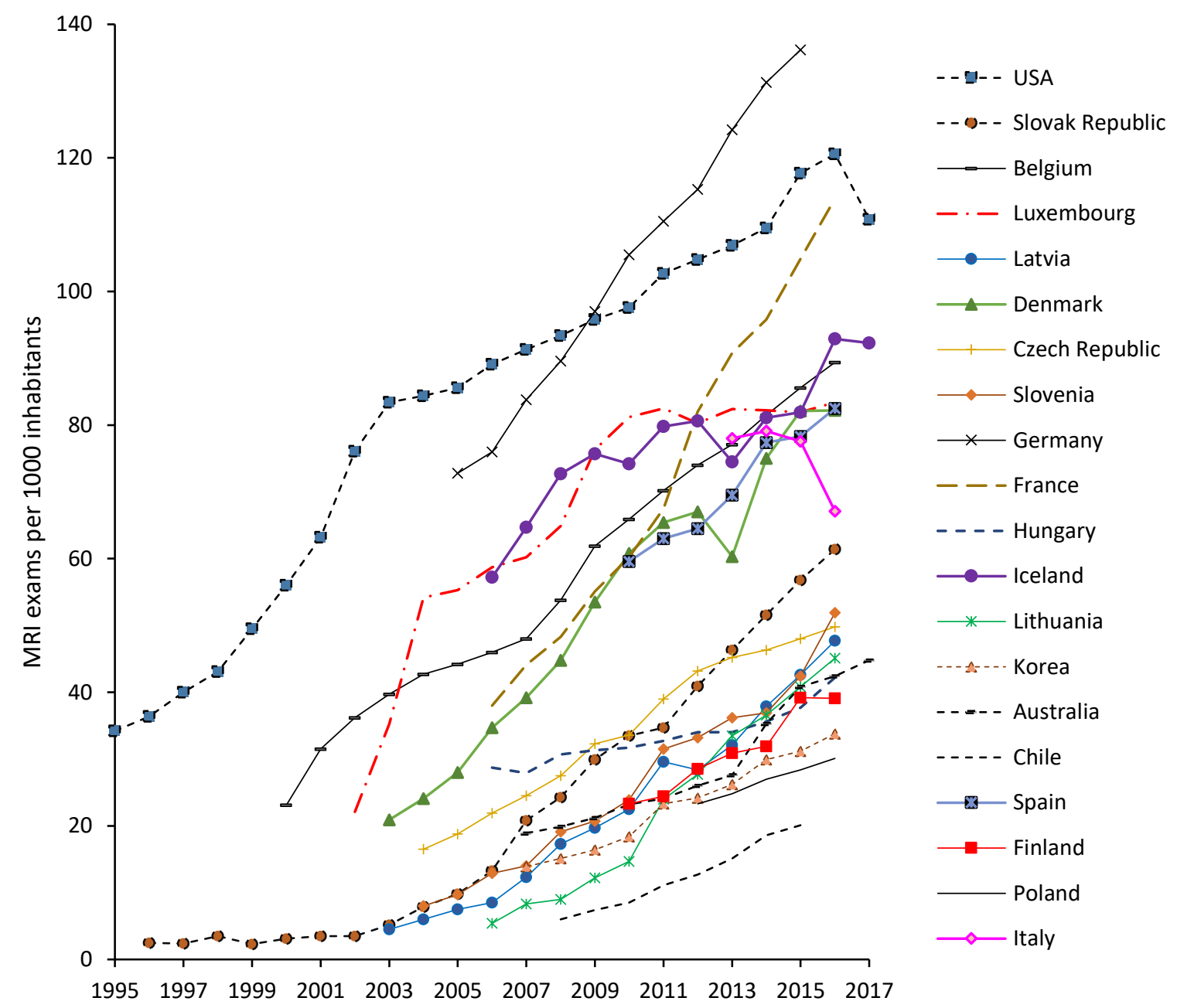

Figure 4. Long-term trend of the number of MRI exams per 1000 inhabitants performed in a range of countries [160].

\section{6. $G d_{\text {anth }}$ in Surface Water}

Since the early report of anthropogenic Gd anomalies in river waters, which was traced back to the increasing use of Gd-CAs in the 1990s [7], similar positive Gd anomalies have been reported in the dissolved load of many urban rivers worldwide (Table 7). However, because anthropogenic $\mathrm{Gd}$ is less particle-reactive and more conservative, the contaminant is expected to be negligibly removed by colloidal organic matter and suspended particles during the estuarine mixing of river water and seawater compared to the removal of other elements in the LA series $[7,11,161]$. This further amplifies positive Gd anomaly of the riverine LA input into seawater and negatively affects the LA signature in coastal waters and in sea basins with restricted water circulation [7]. The difference in magnitude observed between rivers and marine water systems is likely related to the hydrodynamics that efficiently transports contaminants and dilutes the $\mathrm{Gd}_{\text {anth }}$ signal in seawater (Table 7) [1].

Kulaksiz and Bau [15] considered the pattern of water circulation and LA content in surface water and attributed anomalous $\mathrm{Gd}_{\text {anth }}$ in the surface water of the southwestern North Sea off the coast of the East Frisian Islands to the Rhine River, the Ems River, and, feasibly, the Thames River. Besides rivers, ocean submarine outfalls provide a significant load of anthropogenic Gd in seawater. Notwithstanding the fact that plenty of coastal metropolises have adopted ocean submarine outfalls to discharge effluents into oceans after no treatment or only primary treatment, there has been no data regarding the impact of these pipeline systems on the concentrations of LAs in the marine environment until recently. Pedreira et al. [1] investigated the influence of submarine sewage outfalls 
on the distribution of LAs in the Atlantic coastal waters of northeast Brazil and observed the highest positive Gd anomalies in the vicinity of the pipeline system, which decreased with an increasing distance from the point source.

Documented Gd values and calculated positive Gd anomalies in contaminated water resources are listed in Table 7. In San Francisco Bay, increasing from approximately $10 \mathrm{pmol} / \mathrm{kg}$ in 1993 to $20 \mathrm{pmol} / \mathrm{kg}$ in 2000, anthropogenic Gd concentrations surged noticeably over the next 13 years and hit well above $100 \mathrm{pmol} / \mathrm{kg}$ in 2013. Surprisingly, between 2001 and 2013, the proportion of anthropogenic Gd was greater than $50 \%$ (Figure 5) [20].

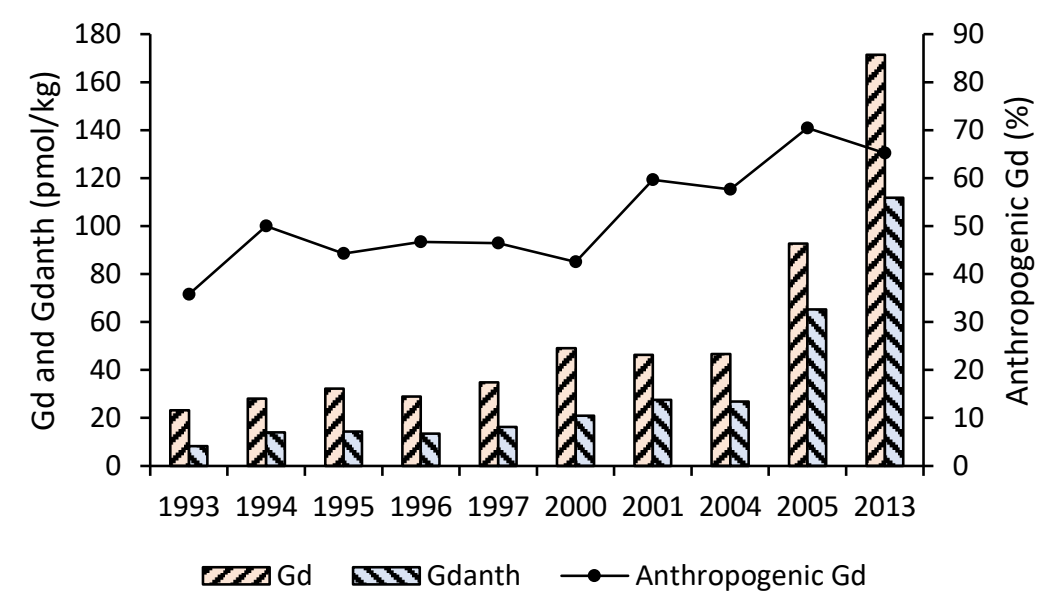

Figure 5. Gd concentration at the Lower South Bay, San Francisco Bay for the period from 1993 to 2013. Water samples were filtered through $0.45-\mu \mathrm{m}$ membranes and acidified to $\mathrm{pH}=1.8$ [20].

When the LA concentrations are normalized, the proportion of LLAs (La to Eu), HLAs (Tb to $\mathrm{Lu}$ ), and Gd (located between LLAs and HLAs) can be plotted on ternary diagrams to gain a better insight into water contamination by Gd-rich wastewater. Since anomalous Gd has been frequently reported in river waters, in this review, the diagrams are generated using the available analytical data for river waters collected at different parts of the world (Figure 6). The natural rivers included in Table 2 have no more than $10 \% \mathrm{Gd}$ and their HLA concentrations are higher than those of LLAs, which is in accordance with Zhu et al. [12] (Figure 6a). In stark contrast, the proportion of Gd is greater than one-third in the majority of effluents and influents of WWTPs with substantial low LLAs (Figure 6b). Depending on the contamination degree and the wastewater percentage in river water, LA patterns can deviate from regular ones and various Gd proportions and HLAs/LLAs ratios can be observed in polluted river waters (Figure 6c). 

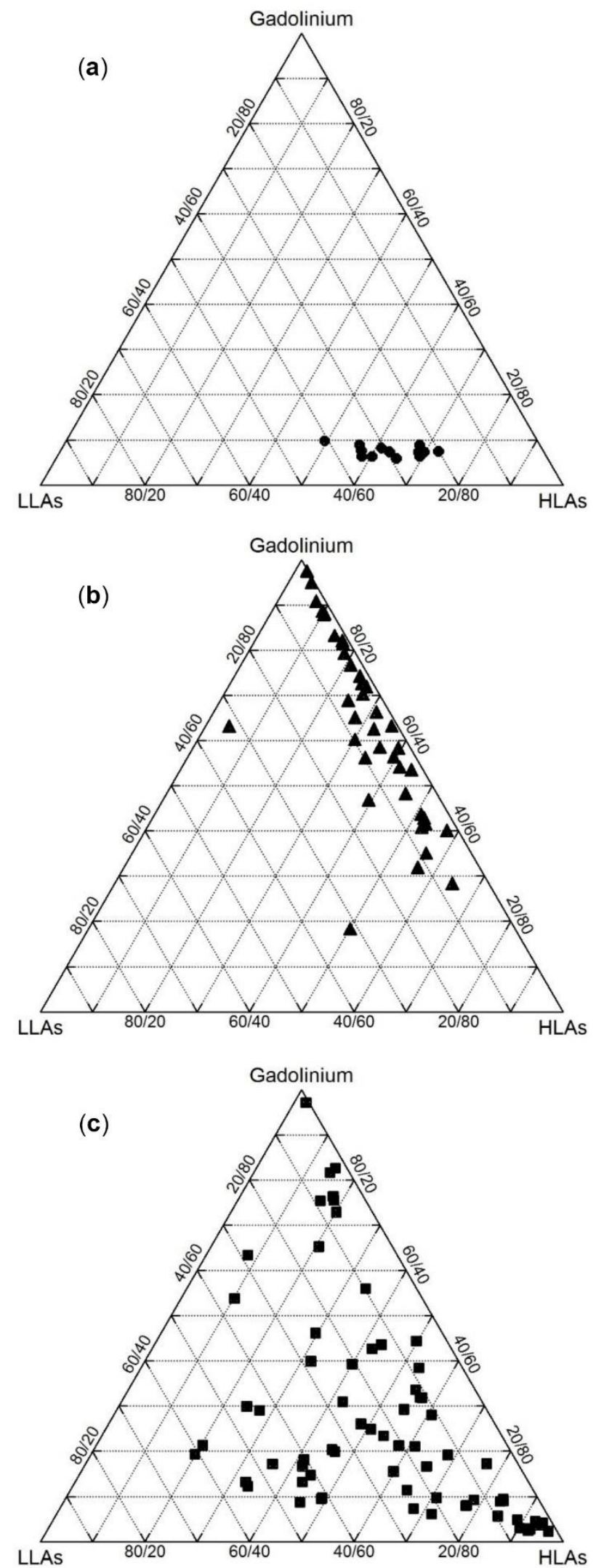

Figure 6. Comparison of LA concentrations (element contents are normalised to MUQ (Mud of Queensland; [87]) in: (a) Uncontaminated river waters; (b) influents and effluents of WWTPs; (c) contaminated river waters. The datasets of the articles listed in Tables 2 and 6 were used. LLAs: La to $\mathrm{Eu}, \mathrm{HLAs:} \mathrm{Tb}$ to $\mathrm{Lu}$ 


\section{7. $G d_{\text {anth }}$ and Surface Water-Groundwater Interaction}

Without efficient sewage treatment processes and tap water purification stages, remarkable anthropogenic Gd can be discharged into surface water resources, transported to groundwater through natural and induced bank filtration, and subsequently transferred to tap water [10]. Gd complexes will not absorb, coprecipitate, or undergo ion exchange processes with organic and inorganic particulate matters, which are corresponded with the characteristics being crucial for their use as MRI diagnostic agents [3]. Positive Gd anomaly in LA distribution patterns of groundwater $[21,153,162,163]$ show that processes, such as bank filtration (natural or induced), do not prevent the migration of $\mathrm{Gd}_{\text {anth }}$ into underground aquifers [10] (Table 7). Recently, attempts have been made to apply the $\mathrm{Gd}_{\text {anth }}$ content in groundwaters, river waters, and seawaters to hydrological studies $[10,21,155,164]$.

$\mathrm{Gd}_{\mathrm{anth}}$, which is a refractory component, can be used as a conservative tracer of sewage effluent $[5,15]$. The changes of $\mathrm{Gd}_{\text {anth }}$ concentrations due to the mixing of bank filtrates and groundwater are well correlated with those of $\delta \mathrm{D}$ and $\delta^{18} \mathrm{O}$, which shows the suitability of using $\mathrm{Gd}_{\mathrm{anth}}$ for hydrological investigations at least on hydrological timescales of days to months [3]. Studying the source of groundwater by stable Gd complexes with a high residence time in the environment was also proposed by Möller et al. [162]. Bau and Dulski [7] evaluated the concentration of dissolved LAs $(<0.2 \mu \mathrm{m}$ fraction) in sewage treatment plant effluent, river water, and tap water in Berlin and indicated that the interaction of groundwater and surface water led to the pronounced positive Gd anomaly in tap water. By means of large positive Gd anomalies, treated wastewater from a local WWTP was traced from nearshore well waters into the coastal ocean, implying submarine groundwater discharge as the major source of LAs to the coastal water along the Kona Coast of the Big Island of Hawaii [21]. Further, over the last 15 years, $\mathrm{Gd}_{\mathrm{anth}}$ content has increased more than four times in the Havel River in Berlin [10]. Considering the migration rate of water from the river to groundwater wells, which takes years to decades, Kulaksız and Bau [10] predicted an increase in nongeogenic Gd in western Berlin tap water over the next few years.

\subsection{Human Health Risks of $G d_{\text {anth }}$}

Gd-CAs have been considered safe for a long period of time. However, potential Gd toxicity has been a health concern due to the $\mathrm{Gd}^{3+}$ ionic radius is roughly equal to $\mathrm{Ca}^{2+}$, which enables the ion to block the calcium ion channels of cells [1]. In addition, $\mathrm{Gd}^{3+}$ regularly binds with a higher affinity than $\mathrm{Ca}^{2+}$ and competes with $\mathrm{Ca}^{2+}$ in physiological processes [165], resulting in a decrease of neuromuscular transmission, and interference in both intracellular enzymes and cell membrane processes through the transmetalation process $[166,167]$. Human beings would not survive $0.1 \mathrm{mmol} / \mathrm{kg}$ free $\mathrm{Gd}$ (e.g., $\mathrm{GdCl}_{2}$ ) being injected into circulation [93].

Severe health concerns recently arose when it was discovered that Gd accumulation in human tissues could be followed by kidney failure [168], nephrogenic systemic fibrosis (NSF) [169,170], and anaphylactic shock [171], and results in death eventually [172]. Patients administered with Gd-CAs may have incorporated part of the Gd chelates into the brain, bone, and kidneys, and even trace amounts of Gd can trigger potentially fatal diseases, including NSF [173-177]. The common signs and symptoms of NSF are painful swelling, hardening and fibrosis under the epidermis with alterations of the normal pattern of collagen bundles as well as proliferation of spindle-shaped dermal cells $[175,178]$. The median time frame between NSF diagnosis and death was just below four months with a median age of 55 years [179]. The administered contrast agent excretion half-life is about $1.5 \mathrm{~h}$ in patients with functional kidneys, but may exceed this by a factor of 20 in those with renal insufficiency [180]. Given the anomalously high Gd concentrations in femoral heads of patients exposed to Gd-CAs (Omniscan and Prohance) 8 years prior to total hip replacement surgery, Darrah et al. [174] suggested the incorporation and retention of MRI Gd chelates into the bone for at least 8 years. The calculated $\mathrm{Gd}$ anomalies ranged up to more than 800 times the natural level.

Since the early reports of brain Gd deposition, many pediatric radiology departments have avoided using less stable linear Gd-CAs (Table 3) [111,112]. Although administrations of gadobutrol 
experienced a negligible rise, the statistics of other Gd-CAs dropped noticeably. The greatest decrease was reported in MRI tests using gadopentetate dimeglumine, which declined from $81 \%$ in 2010 to $15 \%$ in 2016 . Gadoversetamide and gadodiamide were the least popular in $2010(2 \%$ and $10 \%$, respectively) and they were not used six years later anymore. The second most common Gd-CA was gadoterate meglumine in 2016. A considerable decrease of the number of NSF cases was observed after establishing a specific safety policy for the use of Gd-CAs (Table 3) by many scientific societies along with prominent health authorities, such as the Food and Drug Administration (FDA) and the European Medicines Agency (EMA). Furthermore, no new cases were reported after 2009, with the exception of rare isolated cases [181].

It is reported that the renal dysfunction lengthens the residence time of the paramagnetic $\mathrm{Gd}$ chelates inside the organism during which Gd-CAs probably undergo metabolic reactions, such as transmetallation and binding to endogenous compounds. Nonetheless, high level of Gd retention and NSF-like symptoms, such as hardening and swelling of the skin along with pain in different parts of the body, were experienced by some patients with normal renal function who underwent several MRI examinations [182-187]. The hypothesis is that Gd precipitates along with calcium phosphate and forms persistent insoluble deposits with diameters of a few micrometers, triggering the circulation of fibrocytes, which subsequently initiate fibrosis [188]. With their distinct advantages and limitations, a broad range of techniques, such as scanning electron microscopy/energy dispersive X-ray spectroscopy (SEM/EDS), transmission electron microscopy (TEM), secondary ion mass spectrometry (SIMS), extended X-ray absorption fine structure (EXAFS) spectroscopy, synchrotron X-ray fluorescence (SXRF) microscopy, and laser ablation-inductively coupled plasma-mass spectrometry (LA-ICP-MS), are available to perform elemental bio-imaging (EBI) and study insoluble Gd-containing deposits [175,189-193].

McDonald et al. [194] linked the hyperintense dentate nucleus (DN) on unenhanced MRI scans in patients reported by Kasahara et al. [195] to Gd accumulation in the brain area. Previously, Xia et al. [196] assumed that a disrupted blood-brain barrier (BBB) leads to Gd plaques in brain tumors originating from Gd-CAs. Nonetheless, brain Gd accumulation is not limited to those with either a damaged BBB or renal dysfunction [97,197]. Kanda et al. [198,199] found an association between high signal intensity in the brain of patients and frequent Gd-enhanced MRI applications in the past, irrespective of renal dysfunction. Brain Gd retention is not only persistent, but also observable in several parts of the brain, which has turned into a great health concern, resulting in the safety announcement of the Food and Drug Administration (FDA) [176].

\subsection{Ecological Health Risks of $G d_{\text {anth }}$}

Because of high $\mathrm{Gd}_{\mathrm{anth}}$ concentrations in water and $\mathrm{Gd}^{3+}$ toxicity, the potential bioacumulation of Gd chelates by both organisms and plants, which might lead to human exposure through the food chain, and factors (such as the concentration, speciation, and exposure duration) influencing the transport and distribution of $\mathrm{Gd}_{\text {anth }}$ in biota are worth investigating.

\subsubsection{Organisms}

There is some scientific evidence to support the uptake of natural and/or anthropogenic Gd by organisms. Despite the ubiquitous anthropogenic Gd anomalies in the Rhine River and the Weser River (Germany), the flat shale-normalized LA patterns of the aragonitic shell of a freshwater bivalve indicated that no anthropogenic Gd was incorporated into the shells and the difference in the speciation of geogenic and anthropogenic Gd in river waters was highlighted [129]. Furthermore, bioaccumulation of gadopentetic acid (Magnevist ${ }^{\circledR}$ ) by a specific water flea (that are attractive for fish) exposed to polluted water and Gd containing nutrition algae (a marked nutrition for mussels) was recently studied using LA-ICP-MS as a promising tool for bio-imaging [200]. Whilst the exposure through the cultivation medium is followed by Gd signals on the skin and in the intestine, the uptake via nutrition algae led to the highest Gd intensities in the intestine. Therefore, there is a certain 
risk that the Gd-CA can enter the food chain of higher organisms and human beings as well [200]. Interestingly, various Gd sensitivities were documented across four sea urchins species (Paracentrotus lividus, Arbacia lixula, Heliocidaris tuberculate, and Centrostephanus rodgersii) by exposing their embryos to different concentrations of Gadolinium Acetate Tetrahydrate (GAT, Waco) [201]. Since gadolinium severely affected development of the embryos and skeleton growth of the sea urchins, the importance of Gd toxicity tests on several species for risk assessment was highlighted [201].

Recent studies have demonstrated Gd accumulation in the brain regions, liver, kidney, spleen, skin, and bone of different animals [197,202-205]. Bussi et al. [205] attributed various Gd accumulation rates in tissues to different Gd-CA washout rates. Biological retention of Gd is greatly dependent on $\mathrm{Gd}$ species. Non-ionic linear Gd-CAs pose the highest risk for potential Gd retention [147,182,197,206,207]. Contrary to the macrocyclic Gd-CA, gadoterate meglumine, the association of repeated administrations of linear Gd-CAs (gadobenate dimeglumine, gadopentetate dimeglumine, and gadodiamide) with brain Gd retention was reported in healthy rats [208]. According to Kartamihardja et al. [197], the tendency of $\mathrm{Gd}$ retention varies depending on the agent, regardless of renal function. Although renal failure increased short-term Gd retention after Gd-DTPA-BMA administration, it did almost not affect long-term Gd retention for Gd-CAs, implying that the chemical structures of accumulated Gd may be inconsistent and some $\mathrm{Gd}$ is retained initially prior to being removed slowly.

To determine the potential $\mathrm{Gd}^{3+}$ fetal toxicity after maternal gadoteridol intravenous injection, Oh et al. [209] obtained concentrations of the Gd chelate in nonhuman primate placenta, fetal tissues, and amniotic fluid. Compared to the maternal injected dose, the Gd complex concentrations in the fetal tissues and amniotic fluid were minimal, which may alleviate some concerns regarding MRI Gd chelate administration during pregnancy.

\subsubsection{Plants}

The mechanism of toxicity of lanthanides in plants depends on the La speciation, plant species, and growth stage. LAs may interrupt the uptake of various essential plant nutrients, in particular Ca with an almost similar ionic radii. As a result, Ca functions, including the formation of cell walls, root growth, photosynthesis, and flowering, might be interfered with [25]. In wheat, greater $\mathrm{Gd}^{3+}$ bioaccumulation was demonstrated in roots than in aerial parts [210].

Braun et al. [211] investigated four species of aquatic macrophytes (Lemna gibba, Ceratophyllum demersum, Elodea nuttallii, and E. canadensis) as potential biofilters for the removal of different Gd-CAs (Omniscan ${ }^{\circledR}$ and Dotarem $\left.{ }^{\circledR}\right)$ from water. No significant Gd values in the tissues of the macrophytes revealed that the risk of $\mathrm{Gd}_{\mathrm{anth}}$ accumulation in the food chain was low [211]. On the other hand, after the observation of a clear Gd signal in plants sampled downstream of a WWTP, Linder et al. [146] carried out research on the uptake of the Gd-containing contrast agents, Dotarem $®$, Gadovist ${ }^{\circledR}$, and Multihance ${ }^{\circledR}$, by the root system of cress plants under more controlled conditions. In a relatively short time frame, diffusion-driven transport or uptake of considerable amounts of Dotarem $®$ and Gadovist@revealed an inefficiency of the casparian band (the filter system of the root, which normally prevents large molecules being taken up) for the Gd complexes. This might be due to the incomplete establishment of the casparian band in the young tips of the roots [212], leading to the uptake of the complexes through the apoplastic pathway [213]. Using speciation analyses, it was found that the contrast agents (not their metabolites) were taken up by the cress plant and transported to the leaves with no or only negligible modifications [146]. Moreover, uptake of Magnevist ${ }^{\circledR}$ and Omniscan $® b y$ plants cultivated in contaminated water or on contaminated soil irrigated with tap water was studied and accumulation of the Gd-CAs was demonstrated [200]. These findings contradict each other and indicate the need for further investigation to collect more information about the biological uptake and bioaccumulation of Gd-CAs by different plant species at different growth stages, and consequently the biomagnification of the microcontaminant through food chains. 


\section{Knowledge Gaps and Future Research Directions}

Considering the aspects discussed in the previous sections, Figure 7 depicts different likely pathways through which MRI contrast agents pose a threat to human health. The research directions grouped into the following categories seem beneficial to bridge the knowledge gaps and ensure future ecological and human health.

\subsection{Interventions to Prevent/Mitigate Environmental Pollution}

- Little is known about the chemical behavior (degradation and transformation products) of Gd-CAs during the water treatment processes. A wide range of potential ecological and human health risks can be avoided by allocating more financial resources to investigate and upgrade current inefficient wastewater treatment technologies and water purification techniques.

\subsection{Detecting $G d_{\text {anth }}$ as a Microcontaminant in Aqueous Samples and Collecting a Reliable Dataset}

- With the ongoing controversy over securing LA resources and future affordable LA supplies, the environmental aspects are no longer a priority for the industrialized nations. Currently, no extensive LA dataset exists to serve as a background level for monitoring studies, which might be due to a lack of knowledge about their human health risks and ecotoxicology [130]. The dataset should be completed with temporal and spatial data about the distribution of a range of $\mathrm{Gd}$ species in the hydrologic cycle in order to empower decision makers to protect the environment.

- Considering the diversity of preconcentration procedures and the lack of a certified scheme for the recently marketed Gd-CAs, proposing a harmonized method to determine anthropogenic Gd seems necessary. A method accepted by a large group of scientists can facilitate the comparison of data reported from different parts of the world.

- Since various MRI Gd chelates account for the $\mathrm{Gd}_{\mathrm{anth}}$, the capability of the existing preconcentration procedures to efficiently extract $\mathrm{Gd}$ complexes that will be marketed in the future should be verified to prevent underestimation of the anomalous anthropogenic Gd in aqueous samples.

\subsection{Hydrological Studies and Monitoring Other Microcontaminants in Water Resources}

- Those living in small cities may undergo MRI tests in medical centers of neighboring metropolises and excrete the injected Gd-CAs when they get back home. It shows the possibility of investigating either water pollution or surface water-groundwater interactions in cities without MRI centers.

- When the anomalous Gd content can be traced back to WWTPs, it is expected that other emerging microcontaminants, including pharmaceuticals and personal care products (PPCPs), that cannot be completely removed during water treatment also occur in water [214]. Using statistical and machine learning techniques, it would be possible to identify a relationship between different microcontaminants and predict the presence of other chemical constituents without expensive chemical analysis.

\subsection{Ecological and Human Health Risks of $G d_{\text {anth }}$}

- Given the complexity of aquatic environments comprised of different biological systems (e.g., plants, algae, zooplankton, and fish) that differently interact with Gd chelates, there is a risk that Gd-CAs can enter the food chain of higher organisms and human beings. Thus, Gd bioavailability, long-term bioaccumulation of Gd-CAs in the biosphere, their stability in the environment or in biological systems, and the toxicological impacts of Gd complexes are urgent issues that need to be addressed. The uptake of Gd chelates and their bioaccumulation in different parts of plants cultivated in farms and irrigated with polluted water deserve more attention as well. The abovementioned studies might also help to find hyper-accumulator species for $\mathrm{Gd}_{\text {anth }}$. 
- Environmentally relevant concentrations of Gd-containing MRI contrast agents should be considered for further ecotoxicological investigations. In addition, the mixture effect of anthropogenic $\mathrm{Gd}$ and other organic and inorganic stressors on ecotoxicity warrants further research. Thus, the results can be reliably extrapolated to complex environmental systems where $\mathrm{Gd}_{\text {anth }}$ simultaneously exists with numerous chemical compounds.

- In comparison with speciation analysis, the determination of total LA contents to calculate anomalous positive $\mathrm{Gd}$ has been more common. Since the stability of Gd-CAs varies substantially and biological $\mathrm{Gd}$ retention is remarkably dependent on $\mathrm{Gd}$ species, it makes sense to consider various Gd-CAs to interpret their fate in the environment and assess their health risk comprehensively.

- The conventional methodologies (e.g., ICP-OES and ICP-MS) that have been often hyphenated to separation systems, such as HPLC, to quantify the total Gd content or Gd species in different biological tissues provide no spatial resolved information and therefore the precise Gd bioaccumulation remains unknown. The application of recent analytical techniques (including LA-ICP-MS) to create images of the elemental distribution at the cellular range in organisms and plants (bio-imaging) will be advantageous.

- Prevailing winds and ocean currents may transport Gd-containing WWTP effluents towards shores during the high season [1,215]. Given that river water and seawater might be used for drinking purposes or recreational activities, local residents (especially fishermen) and tourists are exposed to anthropogenic Gd through dermal and ingestion pathways. Hence, evaluations of the health risk through chronic and acute exposure scenarios for children and adults would be beneficial.

- Irrespective of renal insufficiency or damaged BBB, Gd retention was observed in the human body after the administration of paramagnetic Gd chelates. Therefore, the investigation of Gd deposition in the human body and the corresponding health problems ought to be stressed. 


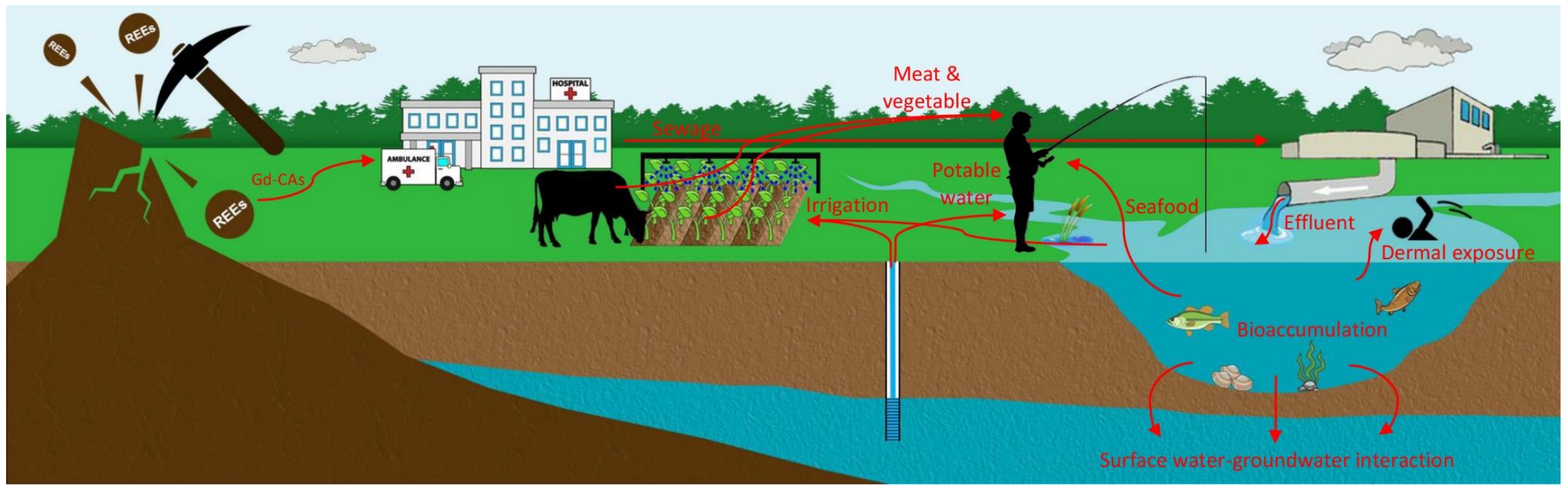

Figure 7. A simplified diagram demonstrating various probable pathways that excreted gadolinium chelates can enter our food chain. To date, anthropogenic Gd has been detected in hospital sewage, WWTP effluent, surface water, groundwater, and tap water. Bioaccumulation of various Gd-CAs in different aquatic species should be further investigated to reach unanimous agreement. Whilst the accumulation of $\mathrm{Gd}$ contrast agent has not been reported in fish, vegetables, and livestock, it is worth investigating to enhance our well-being. Besides, exposure through dermal and ingestion pathways should be evaluated. 


\section{Conclusions}

Many publications and research projects were presented in this review. It was indicated that stable MRI contrast agents have been negligibly removed from wastewater, and discharged into surface water, resulting in the detection of $\mathrm{Gd}_{\mathrm{anth}}$ in river water, seawater, groundwater, and tap water. Moreover, the number of MRI exams is on the increase worldwide, leading to greater $\mathrm{Gd}_{\mathrm{anth}}$ concentrations in water resources in the future. Part of the administered Gd complexes have been incorporated in the brain, bone, and kidneys of patients, and even trace amounts of them can encourage potentially fatal health problems, such as NSF. Although paramagnetic Gd chelates have been detected as a microcontaminant in water resources since the mid-1990s, their uptake and bioaccumulation by different biota have not been thoroughly investigated and, as a result, no permissible limit has been introduced by authorities to screen safe food and water. It is probable that every individual takes up minute daily amounts of $\mathrm{Gd}$ via the consumption of contaminated drinking water and ingredients (meat, seafood, and vegetables) that is considerably higher than the natural doses. Consequently, it is crucial to monitor $\mathrm{Gd}$ species in the environment regularly and promote life-long observations to assess their ecotoxicity and adverse human health effects. Cooperation between medical scientists and environmental experts is highly important to achieve further progress. The discrimination against bioaccumulation of nongeogenic $\mathrm{Gd}$ by at least some organisms and plants corroborates the previous evidence revealing long environmental half-lifes of the paramagnetic Gd chelates. Moreover, it adds to the growing body of evidence suggesting conservative anthropogenic Gd as a useful tracer of WWTP effluents in river water, lake water, seawater, groundwater and tap water. Evaluating the distribution of MRI Gd-CAs also offers a rather inexpensive yet robust way of monitoring xenobiotics, such as pharmaceuticals and personal care products (PPCPs), in water. Although many highly interesting and relevant questions are still to be addressed, the presented analytical methods constitute a perfect base for future research.

Author Contributions: Visualization, P.E.; writing—original draft preparation, P.E.; writing—review and editing, M.B.

Funding: This research received no external funding.

Acknowledgments: The authors would like to express their gratitude towards the anonymous reviewers for careful reading of the manuscript and the constructive comments.

Conflicts of Interest: The authors declare no conflict of interest.

\section{References}

1. Pedreira, R.M.; Pahnke, K.; Böning, P.; Hatje, V. Tracking hospital effluent-derived gadolinium in Atlantic coastal waters off Brazil. Water Res. 2018, 145, 62-72. [CrossRef] [PubMed]

2. Lawrence, M.G.; Bariel, D.G. Tracing treated wastewater in an inland catchment using anthropogenic gadolinium. Chemosphere 2010, 80, 794-799. [CrossRef] [PubMed]

3. Möller, P.; Paces, T.; Dulski, P.; Morteani, G. Anthropogenic Gd in surface water, drainage system, and the water supply of the city of Prague, Czech Republic. Environ. Sci. Technol. 2002, 36, 2387-2394. [CrossRef] [PubMed]

4. Fuganti, A.; Möller, P.; Morteani, G.; Dulski, P. Gadolinio ed altre terre rare usabili come traccianti per stabilire l'eta il movimento ed i rischi delle acque sotterranee: Esempio dell'area di Trento. Geol. Tec. Ambien 1996, 4, 13-18.

5. Möller, P.; Morteani, G.; Dulski, P. Anomalous gadolinium, cerium, and yttrium contents in the adige and isarco river waters and in the water of their tributaries (Provinces Trento and Bolzano/Bozen, NE Italy). Acta Hydrochim. Hydrobiol. 2003, 31, 225-239. [CrossRef]

6. Elbaz-Poulichet, F.; Seidel, J.L.; Othoniel, C. Occurrence of an anthropogenic gadolinium anomaly in river and coastal waters of Southern France. Water Res. 2002, 36, 1102-1105. [CrossRef]

7. Bau, M.; Dulski, P. Anthropogenic origin of positive gadolinium anomalies in river waters. Earth Planet. Sci. Lett. 1996, 143, 245-255. [CrossRef] 
8. Hennebrüder, K.; Wennrich, R.; Mattusch, J.; Stärk, H.-J.; Engewald, W. Determination of gadolinium in river water by SPE preconcentration and ICP-MS. Talanta 2004, 63, 309-316. [CrossRef] [PubMed]

9. Kulaksız, S.; Bau, M. Rare earth elements in the Rhine River, Germany: First case of anthropogenic lanthanum as a dissolved microcontaminant in the hydrosphere. Environ. Int. 2011, 37, 973-979. [CrossRef] [PubMed]

10. Kulaksız, S.; Bau, M. Anthropogenic gadolinium as a microcontaminant in tap water used as drinking water in urban areas and megacities. Appl. Geochem. 2011, 26, 1877-1885. [CrossRef]

11. Nozaki, Y.; Lerche, D.; Alibo, D.S.; Tsutsumi, M. Dissolved indium and rare earth elements in three Japanese rivers and Tokyo Bay: Evidence for anthropogenic Gd and In. Geochim. Cosmochim. Acta 2000, 64, 3975-3982. [CrossRef]

12. Zhu, Y.; Hoshino, M.; Yamada, H.; Itoh, A.; Haraguchi, H. Gadolinium anomaly in the distributions of rare earth elements observed for coastal seawater and river waters around Nagoya City. Bull. Chem. Soc. Jpn. 2004, 77, 1835-1842. [CrossRef]

13. Song, H.; Shin, W.-J.; Ryu, J.-S.; Shin, H.S.; Chung, H.; Lee, K.-S. Anthropogenic rare earth elements and their spatial distributions in the Han River, South Korea. Chemosphere 2017, 172, 155-165. [CrossRef] [PubMed]

14. Nozaki, Y.; Lerche, D.; Alibo, D.S.; Snidvongs, A. The estuarine geochemistry of rare earth elements and indium in the Chao Phraya River, Thailand. Geochim. Cosmochim. Acta 2000, 64, 3983-3994. [CrossRef]

15. Kulaksız, S.; Bau, M. Contrasting behaviour of anthropogenic gadolinium and natural rare earth elements in estuaries and the gadolinium input into the North Sea. Earth Planet. Sci. Lett. 2007, 260, 361-371. [CrossRef]

16. Lawrence, M.G.; Ort, C.; Keller, J. Detection of anthropogenic gadolinium in treated wastewater in South East Queensland, Australia. Water Res. 2009, 43, 3534-3540. [CrossRef]

17. de Campos, F.F.; Enzweiler, J. Anthropogenic gadolinium anomalies and rare earth elements in the water of Atibaia River and Anhumas Creek, Southeast Brazil. Environ. Monit. Assess. 2016, 188, 281. [CrossRef]

18. Bau, M.; Knappe, A.; Dulski, P. Anthropogenic gadolinium as a micropollutant in river waters in Pennsylvania and in Lake Erie, northeastern United States. Chemie der erde-Geochemistry 2006, 66, 143-152. [CrossRef]

19. Smith, C.; Liu, X.-M. Spatial and temporal distribution of rare earth elements in the Neuse River, North Carolina. Chem. Geol. 2018, 488, 34-43. [CrossRef]

20. Hatje, V.; Bruland, K.W.; Flegal, A.R. Increases in anthropogenic gadolinium anomalies and rare earth element concentrations in San Francisco Bay over a 20 year record. Environ. Sci. Technol. 2016, 50, 4159-4168. [CrossRef]

21. Johannesson, K.H.; Palmore, C.D.; Fackrell, J.; Prouty, N.G.; Swarzenski, P.W.; Chevis, D.A.; Telfeyan, K.; White, C.D.; Burdige, D.J. Rare earth element behavior during groundwater-seawater mixing along the Kona Coast of Hawaii. Geochim. Cosmochim. Acta 2017, 198, 229-258. [CrossRef]

22. Schwarzenbach, R.P.; Escher, B.I.; Fenner, K.; Hofstetter, T.B.; Johnson, C.A.; Von Gunten, U.; Wehrli, B. The challenge of micropollutants in aquatic systems. Science 2006, 313, 1072-1077. [CrossRef] [PubMed]

23. Ternes, T.; Joss, A. Human Pharmaceuticals, Hormones and Fragrances; IWA Publishing: London, UK, 2007.

24. Kulaksız, S.; Bau, M. Anthropogenic dissolved and colloid/nanoparticle-bound samarium, lanthanum and gadolinium in the Rhine River and the impending destruction of the natural rare earth element distribution in rivers. Earth Planet. Sci. Lett. 2013, 362, 43-50. [CrossRef]

25. Gwenzi, W.; Mangori, L.; Danha, C.; Chaukura, N.; Dunjana, N.; Sanganyado, E. Sources, behaviour, and environmental and human health risks of high-technology rare earth elements as emerging contaminants. Sci. Total Environ. 2018, 636, 299-313. [CrossRef] [PubMed]

26. Merian, E.; Anke, M.; Ihnat, M.; Stoeppler, M. Elements and Their Compounds in the Environment: Occurrence, Analysis and Biological Relevance; Wiley-VCH Verlag GmbH \& Co. KGaA: Weinheim, Germany, 2004.

27. Kabata-Pendias, A. Trace Elements in Soils and Plants; CRC press: Florida, FL, USA, 2010.

28. Kabata-Pendias, A.; Mukherjee, A.B. Trace Elements from Soil to Human; Springer Science \& Business Media: Berlin, Germany, 2007.

29. Sonich-Mullin, C. Rare Earth Elements: A Review of Production, Processing, Recycling, and Associated Environmental Issues; EPA/600/R-12/572; Office of Research and Development: Washington, DC, USA, 2013; $135 \mathrm{p}$.

30. Migaszewski, Z.M.; Gałuszka, A. The characteristics, occurrence, and geochemical behavior of rare earth elements in the environment: A review. Crit. Rev. Environ. Sci. Technol. 2015, 45, 429-471. [CrossRef] 
31. Ramos, S.J.; Dinali, G.S.; Oliveira, C.; Martins, G.C.; Moreira, C.G.; Siqueira, J.O.; Guilherme, L.R. Rare earth elements in the soil environment. Curr. Pollut. Rep. 2016, 2, 28-50. [CrossRef]

32. Sholkovitz, E.R. The aquatic chemistry of rare earth elements in rivers and estuaries. Aquat. Geochem. 1995, 1, 1-34. [CrossRef]

33. Turetta, C.; Barbaro, E.; Capodaglio, G.; Barbante, C. Dissolved rare earth elements in the central-western sector of the Ross Sea, Southern Ocean: Geochemical tracing of seawater masses. Chemosphere 2017, 183, 444-453. [CrossRef]

34. Petrosino, P.; Sadeghi, M.; Albanese, S.; Andersson, M.; Lima, A.; De Vivo, B. REE contents in solid sample media and stream water from different geological contexts: Comparison between Italy and Sweden. J. Geochem. Explor. 2013, 133, 176-201. [CrossRef]

35. Li, X.-F.; Chen, Z.-B.; Chen, Z.-Q. Distribution and fractionation of rare earth elements in soil-water system and human blood and hair from a mining area in southwest Fujian Province, China. Environ. Earth Sci. 2014, 72, 3599-3608. [CrossRef]

36. Byrne, R.H.; Li, B. Comparative complexation behavior of the rare earths. Geochim. Cosmochim. Acta 1995, 59, 4575-4589. [CrossRef]

37. Enghag, P. Encyclopedia of the Elements: Technical Data-History-Processing-Applications; Wiley-VCH Verlag $\mathrm{GmbH} \& \mathrm{Co} . \mathrm{KGaA}$ : Weinheim, Germany, 2008.

38. U.S. Geological Survey. Metal Prices in the United States through 2010: U.S. Geological Survey Scientific Investigations Report 2012-5188; U.S. Geological Survey: Reston, Virginia, USA, 2013; p. 204.

39. Hedrick, J.B. Rare earths. In Minerals Year Book-2000; U. S. Geological Survey: Washington, DC, USA, 2000; pp. 62.1-62.10.

40. Alonso, E.; Sherman, A.M.; Wallington, T.J.; Everson, M.P.; Field, F.R.; Roth, R.; Kirchain, R.E. Evaluating rare earth element availability: A case with revolutionary demand from clean technologies. Environ. Sci. Technol. 2012, 46, 3406-3414. [CrossRef] [PubMed]

41. Du, X.; Graedel, T. Uncovering the global life cycles of the rare earth elements. Sci. Rep. 2011, 1, 145. [CrossRef] [PubMed]

42. Massari, S.; Ruberti, M. Rare earth elements as critical raw materials: Focus on international markets and future strategies. Resourc. Policy 2013, 38, 36-43. [CrossRef]

43. U.S. Geological Survey. Rare Earth Statistics, in Kelly, T.D., and Matos, G.R., comps., Historical Statistics for Mineral and Material Commodities in the United States: U.S. Geological Survey Data Series 140; US Geological Survey: Reston, Virginia, USA, 2014. Available online: http:/ / minerals.usgs.gov/minerals/pubs/historicalstatistics / (accessed on 7 December 2018).

44. Ahonen, S.; Arvanitidis, N.; Auer, A.; Baillet, E.; Bellato, N.; Binnemans, K.; Blengini, G.A.; Bonato, D.; Brouwer, E.; Brower, S. Strengthening The European Rare Earths Supply-Chain Challenges And Policy Options a Report by the European Rare Earths Competency Network (Erecon); Technical Report; European Commission: Maastricht, The Netherlands, 2015.

45. Newton, D.E.; Edgar, K.J. Chemical Elements; UXL (A Part of Gale, Cengage Learning): Michigan, MI, USA, 2010.

46. Bahl, C.R.H.; Nielsen, K.K. The effect of demagnetization on the magnetocaloric properties of gadolinium. J. Appl. Phys. 2009, 105, 013916. [CrossRef]

47. Humphries, M. Rare Earth Elements: The Global Supply Chain; Congressional Research Service: Washington, DC, USA, 2013.

48. Krishnamurthy, N.; Gupta, C.K. Extractive Metallurgy of Rare Earths; CRC Press: Florida, FL, USA, 2015.

49. Aime, S.; Cabella, C.; Colombatto, S.; Geninatti Crich, S.; Gianolio, E.; Maggioni, F. Insights into the use of paramagnetic Gd (III) complexes in MR-molecular imaging investigations. J. Magn. Reson. Imaging Off. J. Int. Soc. Magn. Resonan. Med. 2002, 16, 394-406. [CrossRef] [PubMed]

50. Babar, S.; Saifuddin, A. MRI of the post-discectomy lumbar spine. Clin. Radiol. 2002, 57, 969-981. [CrossRef]

51. Bencardino, J.T.; Palmer, W.E. Imaging of hip disorders in athletes. Radiol. Clin. N. Am. 2002, 40, 267-287, vi-vii. [CrossRef]

52. Rajagopalan, S.; Prince, M. Magnetic resonance angiographic techniques for the diagnosis of arterial disease. Cardiol. Clin. 2002, 20, 501-512. [CrossRef] 
53. Choudhury, L.; Mahrholdt, H.; Wagner, A.; Choi, K.M.; Elliott, M.D.; Klocke, F.J.; Bonow, R.O.; Judd, R.M.; Kim, R.J. Myocardial scarring in asymptomatic or mildly symptomatic patients with hypertrophic cardiomyopathy. J. Am. College Cardiol. 2002, 40, 2156-2164. [CrossRef]

54. Conaghan, P.G.; O'connor, P.; McGonagle, D.; Astin, P.; Wakefield, R.J.; Gibbon, W.W.; Quinn, M.; Karim, Z.; Green, M.J.; Proudman, S. Elucidation of the relationship between synovitis and bone damage: A randomized magnetic resonance imaging study of individual joints in patients with early rheumatoid arthritis. Arthritis Rheum. 2003, 48, 64-71. [CrossRef] [PubMed]

55. Degani, H.; Chetrit-Dadiani, M.; Bogin, L.; Furman-Haran, E. Magnetic resonance imaging of tumor vasculature. Thromb. Haemost. 2003, 89, 25-33. [PubMed]

56. Stwertka, A. A Guide to the Elements; Oxford University Press: New York, NY, USA, 2002.

57. Taylor, K.C. Automobile catalytic converters. In Catalysis; Springer: Berlin/Heidelberg, Germany, 1984; pp. 119-170.

58. Hurst, C. China's Rare Earth Elements Industry: What Can the West Learn? Institute for the Analysis of Global Security: Washington, DC, USA, 2010.

59. Reimann, C.; De Caritat, P. Chemical Elements in the Environment: Factsheets for the Geochemist and Environmental Scientist; Springer-Verlag: Berlin/Heidelberg, Germany, 1998.

60. Korzh, V.D. Geochemistry of Elemental Composition of the Hydrosphere; Nauka: Moscow, Russia, 1991. (In Russian)

61. Bibak, A.; Stümp, S.; Knudsen, L.; Gundersen, V. Concentrations of 63 elements in cabbage and sprouts in Denmark. Commun. Soil Sci. Plant Anal. 1999, 30, 2409-2418. [CrossRef]

62. Eriksson, J. Concentrations of 61 Trace Elements in Sewage Sludge, Farmyard Manure, Mineral Fertiliser, Precipitation and in Oil and Crops; Swedish Environmental Protection Agency: Stockholm, Sweden, 2001; Volume 5159.

63. Byrne, R.; Sholkovitz, E. Marine chemistry and geochemistry of the lanthanides. In Handbook on the Physics and Chemistry of Rare Earths; North-Holland: Amsterdam, Netherlands, 1996; Volume 23, pp. 497-593.

64. Yan, Z.; Liu, G.; Sun, R.; Tang, Q.; Wu, D.; Wu, B.; Zhou, C. Geochemistry of rare earth elements in groundwater from the Taiyuan Formation limestone aquifer in the Wolonghu Coal Mine, Anhui province, China. J. Geochem. Explor. 2013, 135, 54-62. [CrossRef]

65. Lawrence, M.G.; Greig, A.; Collerson, K.D.; Kamber, B.S. Direct quantification of rare earth element concentrations in natural waters by ICP-MS. Appl. Geochem. 2006, 21, 839-848. [CrossRef]

66. Braun, J.-J.; Pagel, M.; Muller, J.-P.; Bilong, P.; Michard, A.; Guillet, B. Cerium anomalies in lateritic profiles. Geochim. Cosmochim. Acta 1990, 54, 781-795. [CrossRef]

67. Sholkovitz, E.R.; Landing, W.M.; Lewis, B.L. Ocean particle chemistry: The fractionation of rare earth elements between suspended particles and seawater. Geochim. Cosmochim. Acta 1994, 58, 1567-1579. [CrossRef]

68. Leleyter, L.; Probst, J.-L.; Depetris, P.; Haida, S.; Mortatti, J.; Rouault, R.; Samuel, J. Distribution des terres rares dans les sédiments fluviaux: Fractionnement entre les phases labiles et résiduelles. In Comptes rendus de l'Académie des sciences. Série 2. Sciences de la terre et des planètes; 1999; Volume 329, pp. 45-52.

69. Cidu, R.; Biddau, R. Transport of trace elements under different seasonal conditions: Effects on the quality of river water in a Mediterranean area. Appl. Geochem. 2007, 22, 2777-2794. [CrossRef]

70. Aubert, D.; Stille, P.; Probst, A. REE fractionation during granite weathering and removal by waters and suspended loads: Sr and Nd isotopic evidence. Geochim. Cosmochim. Acta 2001, 65, 387-406. [CrossRef]

71. Leybourne, M.I.; Johannesson, K.H. Rare earth elements (REE) and yttrium in stream waters, stream sediments, and Fe-Mn oxyhydroxides: Fractionation, speciation, and controls over REE+ Y patterns in the surface environment. Geochim. Cosmochim. Acta 2008, 72, 5962-5983. [CrossRef]

72. Stallard, R.; Edmond, J. Geochemistry of the Amazon: 2. The influence of geology and weathering environment on the dissolved load. J. Geophys. Res. Oceans 1983, 88, 9671-9688. [CrossRef]

73. Meybeck, M. Global chemical weathering of surficial rocks estimated from river dissolved loads. Am. J. Sci. 1987, 287, 401-428. [CrossRef]

74. Tosiani, T.; Loubet, M.; Viers, J.; Valladon, M.; Tapia, J.; Marrero, S.; Yanes, C.; Ramirez, A.; Dupre, B. Major and trace elements in river-borne materials from the Cuyuni basin (southern Venezuela): Evidence for organo-colloidal control on the dissolved load and element redistribution between the suspended and dissolved load. Chem. Geol. 2004, 211, 305-334. [CrossRef] 
75. Möller, P.; Knappe, A.; Dulski, P. Seasonal variations of rare earths and yttrium distribution in the lowland Havel River, Germany, by agricultural fertilization and effluents of sewage treatment plants. Appl. Geochem. 2014, 41, 62-72. [CrossRef]

76. Haley, B.A.; Frank, M.; Hathorne, E.; Pisias, N. Biogeochemical implications from dissolved rare earth element and $\mathrm{Nd}$ isotope distributions in the Gulf of Alaska. Geochim. Cosmochim. Acta 2014, 126, 455-474. [CrossRef]

77. Fisher, A.; Kara, D. Determination of rare earth elements in natural water samples-A review of sample separation, preconcentration and direct methodologies. Anal. Chim. Acta 2016, 935, 1-29. [CrossRef] [PubMed]

78. Gaillardet, J.; Viers, J.; Dupré, B. Trace elements in river waters. Treatise Geochem. 2003, 5, 605.

79. Alibo, D.S.; Nozaki, Y. Rare earth elements in seawater: Particle association, shale-normalization, and Ce oxidation. Geochim. Cosmochim. Acta 1999, 63, 363-372. [CrossRef]

80. Lawrence, M.G.; Kamber, B.S. The behaviour of the rare earth elements during estuarine mixing-Revisited. Mar. Chem. 2006, 100, 147-161. [CrossRef]

81. McLennan, S.M. Rare earth elements in sedimentary rocks; influence of provenance and sedimentary processes. Rev. Mineral. Geochem. 1989, 21, 169-200.

82. Taylor, S.R.; McClennan, S.M. The Continental Crust: Its Composition and Evolution; Blackwell: Boston, MA, USA, 1985.

83. Rudnick, R.L.; Gao, S. Composition of the continental crust. Treatise Geochem. 2003, 3, 659.

84. Sholkovitz, E.R. Rare earth elements in the sediments of the North Atlantic Ocean, Amazon Delta, and East China Sea; reinterpretation of terrigenous input patterns to the oceans. Am. J. Sci. 1988, 288, $236-281$. [CrossRef]

85. Johannesson, K.H.; Stetzenbach, K.J.; Hodge, V.F.; Kreamer, D.K.; Zhou, X. Delineation of Ground-Water Flow Systems in the Southern Great Basin Using Aqueous Rare Earth Element Distributions. Groundwater 1997, 35, 807-819. [CrossRef]

86. Cidu, R.; Antisari, L.V.; Biddau, R.; Buscaroli, A.; Carbone, S.; Da Pelo, S.; Dinelli, E.; Vianello, G.; Zannoni, D. Dynamics of rare earth elements in water-soil systems: The case study of the Pineta San Vitale (Ravenna, Italy). Geoderma 2013, 193, 52-67. [CrossRef]

87. Kamber, B.S.; Greig, A.; Collerson, K.D. A new estimate for the composition of weathered young upper continental crust from alluvial sediments, Queensland, Australia. Geochim. Cosmochim. Acta 2005, 69, 1041-1058. [CrossRef]

88. Lawrence, M.G.; Jupiter, S.D.; Kamber, B.S. Aquatic geochemistry of the rare earth elements and yttrium in the Pioneer River catchment, Australia. Mar. Freshw. Res. 2006, 57, 725-736. [CrossRef]

89. Haraguchi, H.; Itoh, A.; Kimata, C.; Miwa, H. Speciation of yttrium and lanthanides in natural water by inductively coupled plasma mass spectrometry after preconcentration by ultrafiltration and with a chelating resin. Analyst 1998, 123, 773-778. [CrossRef]

90. Itoh, A.; Nagasawa, T.; Zhu, Y.; Lee, K.-H.; FUJIMORI, E.; HARAGUCHI, H. Distributions of major-to-ultratrace elements among the particulate and dissolved fractions in natural water as studied by ICP-AES and ICP-MS after sequential fractionation. Anal. Sci. 2004, 20, 29-36. [CrossRef] [PubMed]

91. Masuda, A.; Ikeuchi, Y. Lanthanide tetrad effect observed in marine environment. Geochem. J. 1979, 13, 19-22. [CrossRef]

92. Nozaki, Y.; Zhang, J. The rare earth elements and yttrium in the coastal/offshore mixing zone of Tokyo Bay waters and the Kuroshio. In Biogeochemical Processes and Ocean Flux in the Western Pacific; Terra Scientific Publishing Company: Tokyo, Japan, 1995; pp. 171-184.

93. Thomsen, H.S. Are the increasing amounts of gadolinium in surface and tap water dangerous? Acta Radiol. 2017, 58, 259-263. [CrossRef]

94. Holzbecher, E.; Knappe, A.; Pekdeger, A. Identification of degradation characteristics-exemplified by Gd-DTPA in a large experimental column. Environ. Model. Assess. 2005, 10, 1-8. [CrossRef]

95. USEPA. Risk Assessment Guidance for Superfund. Volume I: Human Health Evaluation Manual (Part A); EPA/540/1-89/002; U.S. Environmental Protection Agency: Washington, DC, USA, 1989.

96. Kanal, E. Gadolinium based contrast agents (GBCA): Safety overview after 3 decades of clinical experience. Magn. Reson. Imaging 2016, 34, 1341-1345. [CrossRef] [PubMed] 
97. Clases, D.; Sperling, M.; Karst, U. Analysis of metal-based contrast agents in medicine and the environment. TrAC Trends Anal. Chem. 2018, 104, 135-147. [CrossRef]

98. Weinmann, H.-J.; Brasch, R.C.; Press, W.-R.; Wesbey, G.E. Characteristics of gadolinium-DTPA complex: A potential NMR contrast agent. Am. J. Roentgenol. 1984, 142, 619-624. [CrossRef]

99. Alexander, V. Design and synthesis of macrocyclic ligands and their complexes of lanthanides and actinides. Chem. Rev. 1995, 95, 273-342. [CrossRef]

100. Runge, V.M. Commentary on T1-weighted hypersignal in the deep cerebellar nuclei after repeated administrations of gadolinium-based contrast agents in healthy rats: Difference between linear and macrocyclic agents. Investig. Radiol. 2015, 50, 481-482. [CrossRef] [PubMed]

101. Idée, J.M.; Port, M.; Raynal, I.; Schaefer, M.; Le Greneur, S.; Corot, C. Clinical and biological consequences of transmetallation induced by contrast agents for magnetic resonance imaging: A review. Fundam. Clin. Pharmacol. 2006, 20, 563-576. [CrossRef] [PubMed]

102. Port, M.; Idée, J.-M.; Medina, C.; Robic, C.; Sabatou, M.; Corot, C. Efficiency, thermodynamic and kinetic stability of marketed gadolinium chelates and their possible clinical consequences: A critical review. Biometals 2008, 21, 469-490. [CrossRef]

103. Fraum, T.J.; Ludwig, D.R.; Bashir, M.R.; Fowler, K.J. Gadolinium-based contrast agents: A comprehensive risk assessment. J. Magn. Reson. Imaging 2017, 46, 338-353. [CrossRef]

104. Hao, D.; Ai, T.; Goerner, F.; Hu, X.; Runge, V.M.; Tweedle, M. MRI contrast agents: Basic chemistry and safety. J. Magn. Reson. Imaging 2012, 36, 1060-1071. [CrossRef]

105. Uggeri, F.; Aime, S.; Anelli, P.L.; Botta, M.; Brocchetta, M.; de Haeen, C.; Ermondi, G.; Grandi, M.; Paoli, P. Novel contrast agents for magnetic resonance imaging. Synthesis and characterization of the ligand BOPTA and its Ln (III) complexes ( $\mathrm{Ln}=\mathrm{Gd}, \mathrm{La}, \mathrm{Lu}$ ). X-ray structure of disodium (TPS-9-145337286-CS)-[4-carboxy-5, 8, 11-tris (carboxymethyl)-1-phenyl-2-oxa-5, 8, 11-triazatridecan-13-oato (5-)] gadolinate (2-) in a mixture with its enantiomer. Inorg. Chem. 1995, 34, 633-643.

106. Caravan, P.; Ellison, J.J.; McMurry, T.J.; Lauffer, R.B. Gadolinium (III) chelates as MRI contrast agents: Structure, dynamics, and applications. Chem. Rev. 1999, 99, 2293-2352. [CrossRef] [PubMed]

107. Brücher, E.; Sherry, A. Stability and toxicity of contrast agents. In The Chemistry of Contrast Agents in Medical Magnetic Resonance Imaging; John Wiley \& Sons: West Sussex, UK, 2001; Volume 2.

108. Caravan, P.; Comuzzi, C.; Crooks, W.; McMurry, T.; Choppin, G.; Woulfe, S. Thermodynamic stability and kinetic inertness of MS-325, a new blood pool agent for magnetic resonance imaging. Inorg. Chem. 2001, 40, 2170-2176. [CrossRef] [PubMed]

109. Bellin, M.; Vasile, M.; Morel-Precetti, S. Currently used non-specific extracellular MR contrast media. Eur. Radiol. 2003, 13, 2688-2698. [CrossRef] [PubMed]

110. Moreau, J.; Guillon, E.; Pierrard, J.C.; Rimbault, J.; Port, M.; Aplincourt, M. Complexing Mechanism of the Lanthanide Cations Eu3+, Gd3+, and Tb3+ with 1, 4, 7, 10-Tetrakis (carboxymethyl)-1, 4, 7, 10-tetraazacyclododecane (dota) — Characterization of Three Successive Complexing Phases: Study of the Thermodynamic and Structural Properties of the Complexes by Potentiometry, Luminescence Spectroscopy, and EXAFS. Chem. Eur. J. 2004, 10, 5218-5232. [PubMed]

111. Malayeri, A.A.; Brooks, K.; Bryant, L.H.; Evers, R.; Kumar, P.; Reich, D.S.; Bluemke, D.A. NIH perspective on reports of gadolinium deposition in the brain. J. A. College Radiol. JACR 2016, 13, 237-241. [CrossRef] [PubMed]

112. American College of Radiology-American Society of Neuroradiology. ACR-ASNR Position Statement on the Use of Gadolinium Contrast Agents. Available online: https:/ /www.asnr.org/wpcontent/uploads / 2017/03/ACR_ASNR_Position_Statement_on_the_Use_of_Gadolinium_Contrast_Agents.pdf (accessed on 14 August 2017).

113. European Society of Urogenital Radiology. Available online: http://esur-cm.org/index.php/en/a-generaladverse-reactions-2 (accessed on 14 February 2019).

114. Yang, X.-C.; Sachs, F. Block of stretch-activated ion channels in Xenopus oocytes by gadolinium and calcium ions. Science 1989, 243, 1068-1071. [CrossRef] [PubMed]

115. Telgmann, L.; Sperling, M.; Karst, U. Determination of gadolinium-based MRI contrast agents in biological and environmental samples: A review. Anal. Chim. Acta 2013, 764, 1-16. [CrossRef] [PubMed]

116. Bau, M.; Dulski, P.; Moller, P. Yttrium and holmium in South Pacific seawater: Vertical distribution and possible fractionation mechanisms. Oceanogr. Lit. Rev. 1995, 11, 955. 
117. Behrens, M.K.; Muratli, J.; Pradoux, C.; Wu, Y.; Böning, P.; Brumsack, H.-J.; Goldstein, S.L.; Haley, B.; Jeandel, C.; Paffrath, R. Rapid and precise analysis of rare earth elements in small volumes of seawater-Method and intercomparison. Mar. Chem. 2016, 186, 110-120. [CrossRef]

118. Lawrence, M.G.; Keller, J.; Poussade, Y. Removal of magnetic resonance imaging contrast agents through advanced water treatment plants. Water Sci. Technol. 2010, 61, 685-692. [CrossRef] [PubMed]

119. Zuccato, E.; Calamari, D.; Natangelo, M.; Fanelli, R. Presence of therapeutic drugs in the environment. Lancet 2000, 355, 1789-1790. [CrossRef]

120. Pyrzynska, K.; Kubiak, A.; Wysocka, I. Application of solid phase extraction procedures for rare earth elements determination in environmental samples. Talanta 2016, 154, 15-22. [CrossRef]

121. Augusto, F.; Hantao, L.W.; Mogollón, N.G.; Braga, S.C. New materials and trends in sorbents for solid-phase extraction. TrAC Trends Anal. Chem. 2013, 43, 14-23. [CrossRef]

122. Raju, C.S.K.; Lück, D.; Scharf, H.; Jakubowski, N.; Panne, U. A novel solid phase extraction method for pre-concentration of gadolinium and gadolinium based MRI contrast agents from the environment. J. Anal. Atomic Spectrom. 2010, 25, 1573-1580.

123. Lawrence, M.G. Detection of anthropogenic gadolinium in the Brisbane River plume in Moreton Bay, Queensland, Australia. Mar. Pollut. Bull. 2010, 60, 1113-1116. [CrossRef] [PubMed]

124. Lawrence, M.G.; Kamber, B.S. Rare earth element concentrations in the natural water reference materials (NRCC) NASS-5, CASS-4 and SLEW-3. Geostand. Geoanal. Res. 2007, 31, 95-103. [CrossRef]

125. Shabani, M.B.; Akagi, T.; Masuda, A. Preconcentration of trace rare-earth elements in seawater by complexation with bis (2-ethylhexyl) hydrogen phosphate and 2-ethylhexyl dihydrogen phosphate adsorbed on a C18 cartridge and determination by inductively coupled plasma mass spectrometry. Anal. Chem. 1992, 64, 737-743. [CrossRef]

126. Sawatari, H.; Toda, T.; Saizuka, T.; Kimata, C.; Itoh, A.; Haraguchi, H. Multielement determination of rare earth elements in coastal seawater by inductively coupled plasma mass spectrometry after preconcentration using chelating resin. Bull. Chem. Soc. Jpn. 1995, 68, 3065-3070. [CrossRef]

127. Hatje, V.; Bruland, K.W.; Flegal, A.R. Determination of rare earth elements after pre-concentration using NOBIAS-chelate PA-1®resin: Method development and application in the San Francisco Bay plume. Mar. Chem. 2014, 160, 34-41. [CrossRef]

128. Hennebrüder, K.; Engewald, W.; Stärk, H.-J.; Wennrich, R. Enrichment of rare-earth elements (REE) and Gd-DTPA in surface water samples by means of countercurrent chromatography (CCC). Anal. Chim. Acta 2005, 542, 216-221. [CrossRef]

129. Merschel, G.; Bau, M. Rare earth elements in the aragonitic shell of freshwater mussel Corbicula fluminea and the bioavailability of anthropogenic lanthanum, samarium and gadolinium in river water. Sci. Total Environ. 2015, 533, 91-101. [CrossRef] [PubMed]

130. Kulaksiz, S. Rare Earth Elements as Emerging Contaminants in the Rhine River, Germany and Its Tributaries. Ph.D. Thesis, Jacobs University Bremen, Bremen, Germany, 2012.

131. Meermann, B.; Sperling, M. Hyphenated techniques as tools for speciation analysis of metal-based pharmaceuticals: Developments and applications. Anal. Bioanal. Chem. 2012, 403, 1501-1522. [CrossRef] [PubMed]

132. Mazzucotelli, A.; Bavastello, V.; Magi, E.; Rivaro, P.; Tomba, C. Analysis of gadolinium polyaminopolycarboxylic complexes by HPLC-ultrasonic nebulizer-ICP-AES hyphenated technique. Anal. Proc. incl. Anal. Commun. 1995, 32, 165-167. [CrossRef]

133. Krüger, R.; Braun, K.; Pipkorn, R.; Lehmann, W.D. Characterization of a gadolinium-tagged modular contrast agent by element and molecular mass spectrometry. J. Anal. Atomic Spectrom. 2004, 19, 852-857. [CrossRef]

134. Loreti, V.; Bettmer, J. Determination of the MRI contrast agent Gd-DTPA by SEC-ICP-MS. Anal. Bioanal. Chem. 2004, 379, 1050-1054. [CrossRef] [PubMed]

135. Pfundstein, P.; Martin, C.; Schulz, W.; Ruth, K.M.; Wille, A.; Moritz, T.; Steinbach, A.; Flottmann, D. IC-ICP-MS analysis of gadolinium-based MRI contrast agents. LC GC N. Am. 2011, 29, 27-29.

136. Moutiez, E.; Prognon, P.; Mahuzier, G.; Bourrinet, P.; Zehaf, S.; Dencausse, A. Time-resolved Luminescence as a Novel Detection Mode for the Simultaneous High-performance Liquid Chromatographic Determination of Gadolinium-DOTA and Gd 3+. Analyst 1997, 122, 1347-1352. [CrossRef]

137. Hagan, J.J.; Taylor, S.C.; Tweedle, M.F. Fluorescence detection of gadolinium chelates separated by reversed-phase high-performance liquid chromatography. Anal. Chem. 1988, 60, 514-516. [CrossRef] 
138. Künnemeyer, J.; Terborg, L.; Nowak, S.; Scheffer, A.; Telgmann, L.; Tokmak, F.; Günsel, A.; Wiesmüller, G.; Reichelt, S.; Karst, U. Speciation analysis of gadolinium-based MRI contrast agents in blood plasma by hydrophilic interaction chromatography/electrospray mass spectrometry. Anal. Chem. 2008, 80, 8163-8170. [CrossRef] [PubMed]

139. Künnemeyer, J.; Terborg, L.; Nowak, S.; Brauckmann, C.; Telgmann, L.; Albert, A.; Tokmak, F.; Krämer, B.K.; Günsel, A.; Wiesmüller, G.A. Quantification and excretion kinetics of a magnetic resonance imaging contrast agent by capillary electrophoresis-mass spectrometry. Electrophoresis 2009, 30, 1766-1773. [CrossRef] [PubMed]

140. Kahakachchi, C.L.; Moore, D.A. Speciation of gadolinium in gadolinium-based magnetic resonance imaging agents by high performance liquid chromatography inductively coupled plasma optical emission spectrometry. J. Anal. Atomic Spectrom. 2009, 24, 1389-1396. [CrossRef]

141. Kahakachchi, C.L.; Moore, D.A. Identification and characterization of gadolinium (III) complexes in biological tissue extracts. Metallomics 2010, 2, 490-497. [CrossRef]

142. Künnemeyer, J.; Terborg, L.; Meermann, B.r.; Brauckmann, C.; Möller, I.; Scheffer, A.; Karst, U. Speciation analysis of gadolinium chelates in hospital effluents and wastewater treatment plant sewage by a novel HILIC/ICP-MS method. Environ. Sci. Technol. 2009, 43, 2884-2890. [CrossRef]

143. Raju, C.S.K.; Cossmer, A.; Scharf, H.; Panne, U.; Lück, D. Speciation of gadolinium based MRI contrast agents in environmental water samples using hydrophilic interaction chromatography hyphenated with inductively coupled plasma mass spectrometry. J. Anal. Atomic Spectrom. 2010, 25, 55-61. [CrossRef]

144. Telgmann, L.; Wehe, C.A.; Birka, M.; Künnemeyer, J.; Nowak, S.; Sperling, M.; Karst, U. Speciation and isotope dilution analysis of gadolinium-based contrast agents in wastewater. Environ. Sci. Technol. 2012, 46, 11929-11936. [CrossRef] [PubMed]

145. Birka, M.; Wehe, C.A.; Telgmann, L.; Sperling, M.; Karst, U. Sensitive quantification of gadolinium-based magnetic resonance imaging contrast agents in surface waters using hydrophilic interaction liquid chromatography and inductively coupled plasma sector field mass spectrometry. J. Chromatogr. A 2013, 1308, 125-131. [CrossRef] [PubMed]

146. Lindner, U.; Lingott, J.; Richter, S.; Jakubowski, N.; Panne, U. Speciation of gadolinium in surface water samples and plants by hydrophilic interaction chromatography hyphenated with inductively coupled plasma mass spectrometry. Anal. Bioanal. Chem. 2013, 405, 1865-1873. [CrossRef] [PubMed]

147. Birka, M.; Wentker, K.S.; Lusmöller, E.; Arheilger, B.; Wehe, C.A.; Sperling, M.; Stadler, R.; Karst, U. Diagnosis of nephrogenic systemic fibrosis by means of elemental bioimaging and speciation analysis. Anal. Chem. 2015, 87, 3321-3328. [CrossRef] [PubMed]

148. Lindner, U.; Lingott, J.; Richter, S.; Jiang, W.; Jakubowski, N.; Panne, U. Analysis of gadolinium-based contrast agents in tap water with a new hydrophilic interaction chromatography (ZIC-cHILIC) hyphenated with inductively coupled plasma mass spectrometry. Anal. Bioanal. Chem. 2015, 407, 2415-2422. [CrossRef]

149. Birka, M.; Wehe, C.A.; Hachmöller, O.; Sperling, M.; Karst, U. Tracing gadolinium-based contrast agents from surface water to drinking water by means of speciation analysis. J. Chromatogr. A 2016, 1440, 105-111. [CrossRef] [PubMed]

150. Wells, W.H.; Wells, V.L. The Lanthanides, Rare Earth Elements. Patty's Toxicol. 2001, 817-840. [CrossRef]

151. Elderfield, H.; Upstill-Goddard, R.; Sholkovitz, E. The rare earth elements in rivers, estuaries, and coastal seas and their significance to the composition of ocean waters. Geochim. Cosmochim. Acta 1990, 54, 971-991. [CrossRef]

152. Sholkovitz, E.R. Chemical evolution of rare earth elements: Fractionation between colloidal and solution phases of filtered river water. Earth Planet. Sci. Lett. 1992, 114, 77-84. [CrossRef]

153. Knappe, A.; Möller, P.; Dulski, P.; Pekdeger, A. Positive gadolinium anomaly in surface water and ground water of the urban area Berlin, Germany. Chemie der erde-Geochemistry 2005, 65, 167-189. [CrossRef]

154. Kümmerer, K.; Helmers, E. Hospital effluents as a source of gadolinium in the aquatic environment. Environ. Sci. Technol. 2000, 34, 573-577. [CrossRef]

155. Brünjes, R.; Bichler, A.; Hoehn, P.; Lange, F.T.; Brauch, H.-J.; Hofmann, T. Anthropogenic gadolinium as a transient tracer for investigating river bank filtration. Sci. Total Environ. 2016, 571, 1432-1440. [CrossRef]

156. Verplanck, P.L.; Taylor, H.E.; Nordstrom, D.K.; Barber, L.B. Aqueous stability of gadolinium in surface waters receiving sewage treatment plant effluent, Boulder Creek, Colorado. Environ. Sci. Technol. 2005, 39, 6923-6929. [CrossRef] 
157. Merschel, G.; Bau, M.; Baldewein, L.; Dantas, E.L.; Walde, D.; Bühn, B. Tracing and tracking wastewater-derived substances in freshwater lakes and reservoirs: Anthropogenic gadolinium and geogenic REEs in Lake Paranoá, Brasilia. Comptes Rendus Geosci. 2015, 347, 284-293. [CrossRef]

158. Kümmerer, K. Pharmaceuticals in the Environment: Sources, Fate, Effects and Risks; Springer Science \& Business Media: Berlin, Germany, 2008.

159. Verplanck, P.L.; Furlong, E.T.; Gray, J.L.; Phillips, P.J.; Wolf, R.E.; Esposito, K. Evaluating the behavior of gadolinium and other rare earth elements through large metropolitan sewage treatment plants. Environ. Sci. Technol. 2010, 44, 3876-3882. [CrossRef]

160. OECD. Magnetic Resonance Imaging (MRI) Exams. Available online: https://doi.org/10.1787/1d89353f-en (accessed on 7 December 2018).

161. Censi, P.; Zuddas, P.; Randazzo, L.; Saiano, F.; Mazzola, S.; Arico, P.; Cuttitta, A.; Punturo, R. Influence of dissolved organic matter on rare earth elements and yttrium distributions in coastal waters. Chem. Ecol. 2010, 26, 123-135. [CrossRef]

162. Möller, P.; Dulski, P.; Bau, M.; Knappe, A.; Pekdeger, A.; Sommer-von Jarmersted, C. Anthropogenic gadolinium as a conservative tracer in hydrology. J. Geochem. Explor. 2000, 69, 409-414. [CrossRef]

163. Rabiet, M.; Brissaud, F.; Seidel, J.; Pistre, S.; Elbaz-Poulichet, F. Positive gadolinium anomalies in wastewater treatment plant effluents and aquatic environment in the Hérault watershed (South France). Chemosphere 2009, 75, 1057-1064. [CrossRef] [PubMed]

164. Bichler, A.; Muellegger, C.; Brünjes, R.; Hofmann, T. Quantification of river water infiltration in shallow aquifers using acesulfame and anthropogenic gadolinium. Hydrol. Process. 2016, 30, 1742-1756. [CrossRef]

165. Sherry, A.D.; Caravan, P.; Lenkinski, R.E. Primer on gadolinium chemistry. J. Magn. Reson. Imaging Off. J. Int. Soc. Magn. Reson. Med. 2009, 30, 1240-1248. [CrossRef] [PubMed]

166. Shellock, F.G.; Spinazzi, A. MRI safety update 2008: Part 1, MRI contrast agents and nephrogenic systemic fibrosis. Am. J. Roentgenol. 2008, 191, 1129-1139. [CrossRef] [PubMed]

167. Mundim, J.S.; Lorena, S.d.C.; Abensur, H.; Elias, R.M.; Moysés, R.M.A.; MARTINS, M.C.; CASTRO, J.E.R. Fibrose sistêmica nefrogênica: Uma complicação grave do uso do gadolínio em pacientes com insuficiência renal. Rev. Assoc. Med. Bras. 2009, 55, 220-225. [CrossRef]

168. Ergün, I.; Keven, K.; Uruc, I.; Ekmekci, Y.; Canbakan, B.; Erden, I.; Karatan, O. The safety of gadolinium in patients with stage 3 and 4 renal failure. Nephrol. Dial. Transplant. 2005, 21, 697-700. [CrossRef]

169. Marckmann, P.; Skov, L.; Rossen, K.; Heaf, J.G.; Thomsen, H.S. Case-control study of gadodiamide-related nephrogenic systemic fibrosis. Nephrol. Dial. Transplant. 2007, 22, 3174-3178. [CrossRef]

170. Thakral, C.; Alhariri, J.; Abraham, J.L. Long-term retention of gadolinium in tissues from nephrogenic systemic fibrosis patient after multiple gadolinium-enhanced MRI scans: Case report and implications. Contrast Media Mol. Imaging 2007, 2, 199-205. [CrossRef]

171. Hasdenteufel, F.; Luyasu, S.; Renaudin, J.-M.; Paquay, J.-L.; Carbutti, G.; Beaudouin, E.; Moneret-Vautrin, D.A.; Kanny, G. Anaphylactic shock after first exposure to gadoterate meglumine: Two case reports documented by positive allergy assessment. J. Allergy Clin. Immunol. 2008, 121, 527-528. [CrossRef]

172. Kay, J. Nephrogenic systemic fibrosis: A gadolinium-associated fibrosing disorder in patients with renal dysfunction. Ann. Rheum. Dis. 2008, 67, iii66-iii69. [CrossRef] [PubMed]

173. White, G.W.; Gibby, W.A.; Tweedle, M.F. Comparison of Gd (DTPA-BMA)(Omniscan) versus Gd (HP-DO3A)(ProHance) relative to gadolinium retention in human bone tissue by inductively coupled plasma mass spectroscopy. Investig. Radiol. 2006, 41, 272-278. [CrossRef] [PubMed]

174. Darrah, T.H.; Prutsman-Pfeiffer, J.J.; Poreda, R.J.; Campbell, M.E.; Hauschka, P.V.; Hannigan, R.E. Incorporation of excess gadolinium into human bone from medical contrast agents. Metallomics 2009, 1, 479-488. [CrossRef] [PubMed]

175. Thakral, C.; Abraham, J.L. Gadolinium-induced nephrogenic systemic fibrosis is associated with insoluble Gd deposits in tissues: In vivo transmetallation confirmed by microanalysis. J. Cutan. Pathol. 2009, 36, 1244-1254. [CrossRef] [PubMed]

176. US Food and Drug Administration. FDA Drug Safety Communication: FDA Evaluating the Risk of Brain Deposits with Repeated Use of Gadolinium-Based Contrast Agents for Magnetic Resonance Imaging (MRI); US Food and Drug Administration: Silver Spring, MD, USA, 2015.

177. Rogosnitzky, M.; Branch, S. Gadolinium-based contrast agent toxicity: A review of known and proposed mechanisms. Biometals 2016, 29, 365-376. [CrossRef] [PubMed] 
178. Cowper, S.E.; Robin, H.S.; Steinberg, S.M.; Su, L.D.; Gupta, S.; LeBoit, P.E. Scleromyxoedema-like cutaneous diseases in renal-dialysis patients. Lancet 2000, 356, 1000-1001. [CrossRef]

179. Swaminathan, S.; High, W.; Ranville, J.; Horn, T.; Hiatt, K.; Thomas, M.; Brown, H.; Shah, S. Cardiac and vascular metal deposition with high mortality in nephrogenic systemic fibrosis. Kidney Int. 2008, 73, 1413-1418. [CrossRef]

180. Idee, J.-M.; Port, M.; Medina, C.; Lancelot, E.; Fayoux, E.; Ballet, S.; Corot, C. Possible involvement of gadolinium chelates in the pathophysiology of nephrogenic systemic fibrosis: A critical review. Toxicology 2008, 248, 77-88. [CrossRef]

181. Larson, K.N.; Gagnon, A.L.; Darling, M.D.; Patterson, J.W.; Cropley, T.G. Nephrogenic systemic fibrosis manifesting a decade after exposure to gadolinium. JAMA Dermatol. 2015, 151, 1117-1120. [CrossRef]

182. Sieber, M.A.; Lengsfeld, P.; Frenzel, T.; Golfier, S.; Schmitt-Willich, H.; Siegmund, F.; Walter, J.; Weinmann, H.-J.; Pietsch, H. Preclinical investigation to compare different gadolinium-based contrast agents regarding their propensity to release gadolinium in vivo and to trigger nephrogenic systemic fibrosis-like lesions. Eur. Radiol. 2008, 18, 2164-2173. [CrossRef] [PubMed]

183. Gathings, R.M.; Reddy, R.; Santa Cruz, D.; Brodell, R.T. Gadolinium-associated plaques: A new, distinctive clinical entity. JAMA Dermatol. 2015, 151, 316-319. [CrossRef] [PubMed]

184. Semelka, R.C.; Commander, C.W.; Jay, M.; Burke, L.M.; Ramalho, M. Presumed gadolinium toxicity in subjects with normal renal function: A report of 4 cases. Investig. Radiol. 2016, 51, 661-665. [CrossRef] [PubMed]

185. Semelka, R.C.; Ramalho, J.; Vakharia, A.; AlObaidy, M.; Burke, L.M.; Jay, M.; Ramalho, M. Gadolinium deposition disease: Initial description of a disease that has been around for a while. Magn. Reson. Imaging 2016, 34, 1383-1390. [CrossRef]

186. Burke, L.M.; Ramalho, M.; AlObaidy, M.; Chang, E.; Jay, M.; Semelka, R.C. Self-reported gadolinium toxicity: A survey of patients with chronic symptoms. Magn. Reson. Imaging 2016, 34, 1078-1080. [CrossRef] [PubMed]

187. Roberts, D.R.; Lindhorst, S.M.; Welsh, C.T.; Maravilla, K.R.; Herring, M.N.; Braun, K.A.; Thiers, B.H.; Davis, W.C. High levels of gadolinium deposition in the skin of a patient with normal renal function. Investig. Radiol. 2016, 51, 280-289. [CrossRef] [PubMed]

188. Semelka, R.C.; Ramalho, M.; AlObaidy, M.; Ramalho, J. Gadolinium in humans: A family of disorders. Am. J. Roentgenol. 2016, 207, 229-233. [CrossRef]

189. Abraham, J.L.; Chandra, S.; Thakral, C.; Abraham, J.M. SIMS imaging of gadolinium isotopes in tissue from Nephrogenic Systemic Fibrosis patients: Release of free Gd from magnetic resonance imaging (MRI) contrast agents. Appl. Surf. Sci. 2008, 255, 1181-1184. [CrossRef]

190. George, S.J.; Webb, S.M.; Abraham, J.L.; Cramer, S.P. Synchrotron X-ray analyses demonstrate phosphate-bound gadolinium in skin in nephrogenic systemic fibrosis. Br. J. Dermatol. 2010, 163, 1077-1081. [CrossRef]

191. Qin, Z.; Caruso, J.A.; Lai, B.; Matusch, A.; Becker, J.S. Trace metal imaging with high spatial resolution: Applications in biomedicine. Metallomics 2011, 3, 28-37. [CrossRef]

192. Jurowski, K.; Buszewski, B.; Piekoszewski, W. Bioanalytics in quantitive (bio) imaging/mapping of metallic elements in biological samples. Crit. Rev. Anal. Chem. 2015, 45, 334-347. [CrossRef] [PubMed]

193. Fingerhut, S.; Niehoff, A.-C.; Sperling, M.; Jeibmann, A.; Paulus, W.; Niederstadt, T.; Allkemper, T.; Heindel, W.; Holling, M.; Karst, U. Spatially resolved quantification of gadolinium deposited in the brain of a patient treated with gadolinium-based contrast agents. J. Trace Elem. Med. Biol. 2018, 45, 125-130. [CrossRef] [PubMed]

194. McDonald, R.J.; McDonald, J.S.; Kallmes, D.F.; Jentoft, M.E.; Murray, D.L.; Thielen, K.R.; Williamson, E.E.; Eckel, L.J. Intracranial gadolinium deposition after contrast-enhanced MR imaging. Radiology 2015, 275, 772-782. [CrossRef] [PubMed]

195. Kasahara, S.; Miki, Y.; Kanagaki, M.; Yamamoto, A.; Mori, N.; Sawada, T.; Taoka, T.; Okada, T.; Togashi, K. Hyperintense dentate nucleus on unenhanced T1-weighted MR images is associated with a history of brain irradiation. Radiology 2011, 258, 222-228. [CrossRef] [PubMed]

196. Xia, D.; Davis, R.L.; Crawford, J.A.; Abraham, J.L. Gadolinium released from MR contrast agents is deposited in brain tumors: In situ demonstration using scanning electron microscopy with energy dispersive X-ray spectroscopy. Acta Radiol. 2010, 51, 1126-1136. [CrossRef] [PubMed] 
197. Kartamihardja, A.A.P.; Nakajima, T.; Kameo, S.; Koyama, H.; Tsushima, Y. Impact of impaired renal function on gadolinium retention after administration of gadolinium-based contrast agents in a mouse model. Investig. Radiol. 2016, 51, 655-660. [CrossRef]

198. Kanda, T.; Ishii, K.; Kawaguchi, H.; Kitajima, K.; Takenaka, D. High signal intensity in the dentate nucleus and globus pallidus on unenhanced T1-weighted MR images: Relationship with increasing cumulative dose of a gadolinium-based contrast material. Radiology 2013, 270, 834-841. [CrossRef]

199. Kanda, T.; Fukusato, T.; Matsuda, M.; Toyoda, K.; Oba, H.; Kotoku, J.i.; Haruyama, T.; Kitajima, K.; Furui, S. Gadolinium-based contrast agent accumulates in the brain even in subjects without severe renal dysfunction: Evaluation of autopsy brain specimens with inductively coupled plasma mass spectroscopy. Radiology 2015, 276, 228-232. [CrossRef]

200. Lingott, J.; Lindner, U.; Telgmann, L.; Esteban-Fernández, D.; Jakubowski, N.; Panne, U. Gadolinium-uptake by aquatic and terrestrial organisms-distribution determined by laser ablation inductively coupled plasma mass spectrometry. Environ. Sci. Process. Impacts 2016, 18, 200-207. [CrossRef]

201. Martino, C.; Bonaventura, R.; Byrne, M.; Roccheri, M.; Matranga, V. Effects of exposure to gadolinium on the development of geographically and phylogenetically distant sea urchins species. Mar. Environ. Res. 2017, 128, 98-106. [CrossRef]

202. Wáng, Y.-X.J.; Schroeder, J.; Siegmund, H.; Idée, J.-M.; Fretellier, N.; Jestin-Mayer, G.; Factor, C.; Deng, M.; Kang, W.; Morcos, S.K. Total gadolinium tissue deposition and skin structural findings following the administration of structurally different gadolinium chelates in healthy and ovariectomized female rats. Quant. Imaging in Med. Surg. 2015, 5, 534.

203. Lohrke, J.; Frisk, A.-L.; Frenzel, T.; Schöckel, L.; Rosenbruch, M.; Jost, G.; Lenhard, D.C.; Sieber, M.A.; Nischwitz, V.; Küppers, A. Histology and gadolinium distribution in the rodent brain after the administration of cumulative high doses of linear and macrocyclic gadolinium-based contrast agents. Investig. Radiol. 2017, 52, 324. [CrossRef] [PubMed]

204. McDonald, R.J.; McDonald, J.S.; Dai, D.; Schroeder, D.; Jentoft, M.E.; Murray, D.L.; Kadirvel, R.; Eckel, L.J.; Kallmes, D.F. Comparison of gadolinium concentrations within multiple rat organs after intravenous administration of linear versus macrocyclic gadolinium chelates. Radiology 2017, 285, 536-545. [CrossRef] [PubMed]

205. Bussi, S.; Coppo, A.; Botteron, C.; Fraimbault, V.; Fanizzi, A.; De Laurentiis, E.; Colombo Serra, S.; Kirchin, M.A.; Tedoldi, F.; Maisano, F. Differences in gadolinium retention after repeated injections of macrocyclic MR contrast agents to rats. J. Magn. Reson. Imaging 2018, 47, 746-752. [CrossRef] [PubMed]

206. Kanda, T.; Nakai, Y.; Oba, H.; Toyoda, K.; Kitajima, K.; Furui, S. Gadolinium deposition in the brain. Magn. Reson. Imaging 2016, 34, 1346-1350. [CrossRef] [PubMed]

207. Murata, N.; Gonzalez-Cuyar, L.F.; Murata, K.; Fligner, C.; Dills, R.; Hippe, D.; Maravilla, K.R. Macrocyclic and other non-group 1 gadolinium contrast agents deposit low levels of gadolinium in brain and bone tissue: Preliminary results from 9 patients with normal renal function. Investig. Radiol. 2016, 51, 447-453. [CrossRef] [PubMed]

208. Robert, P.; Violas, X.; Grand, S.; Lehericy, S.; Idée, J.-M.; Ballet, S.; Corot, C. Linear gadolinium-based contrast agents are associated with brain gadolinium retention in healthy rats. Investig. Radiol. 2016, 51, 73. [CrossRef]

209. Oh, K.Y.; Roberts, V.H.; Schabel, M.C.; Grove, K.L.; Woods, M.; Frias, A.E. Gadolinium chelate contrast material in pregnancy: Fetal biodistribution in the nonhuman primate. Radiology 2015, 276, 110-118. [CrossRef]

210. Zhimang, G.; Xiaorong, W.; Xueyuan, G.; Jing, C.; Liansheng, W.; Lemei, D.; Yijun, C. Effects of fulvic acid on the bioavailability of rare earth elements and GOT enzyme activity in wheat (Triticum aestivum). Chemosphere 2001, 44, 545-551. [CrossRef]

211. Braun, M.; Zavanyi, G.; Laczovics, A.; Berényi, E.; Szabó, S. Can aquatic macrophytes be biofilters for gadolinium based contrasting agents? Water Res. 2018, 135, 104-111. [CrossRef]

212. Yeo, A.R.; Yeo, M.E.; Flowers, T.J. The contribution of an apoplastic pathway to sodium uptake by rice roots in saline conditions. J. Exp. Bot. 1987, 38, 1141-1153. [CrossRef]

213. Nowack, B.; Schulin, R.; Robinson, B.H. Critical assessment of chelant-enhanced metal phytoextraction. Environ. Sci. Technol. 2006, 40, 5225-5232. [CrossRef] [PubMed] 
214. Ternes, T.A. Occurrence of drugs in German sewage treatment plants and rivers1. Water Res. 1998, 32, 3245-3260. [CrossRef]

215. Roth, F.; Lessa, G.; Wild, C.; Kikuchi, R.; Naumann, M. Impacts of a high-discharge submarine sewage outfall on water quality in the coastal zone of Salvador (Bahia, Brazil). Mar. Pollut. Bull. 2016, 106, 43-48. [CrossRef] [PubMed] 